Florida International University FIU Digital Commons

FIU Electronic Theses and Dissertations

University Graduate School

10-18-2004

\title{
Cytotoxicity and drug potentiating activity of phenylheptatriyne
}

Rachel Arrasmith Gray

Florida International University

DOI: $10.25148 /$ etd.FI15101680

Follow this and additional works at: https://digitalcommons.fiu.edu/etd

Part of the Biology Commons

\section{Recommended Citation}

Gray, Rachel Arrasmith, "Cytotoxicity and drug potentiating activity of phenylheptatriyne" (2004). FIU Electronic Theses and Dissertations. 2433.

https://digitalcommons.fiu.edu/etd/2433

This work is brought to you for free and open access by the University Graduate School at FIU Digital Commons. It has been accepted for inclusion in FIU Electronic Theses and Dissertations by an authorized administrator of FIU Digital Commons. For more information, please contact dcc@fiu.edu. 


\section{FLORIDA INTERNATIONAL UNIVERSITY}

Miami, Florida

\section{CYTOTOXICITY AND DRUG POTENTIATING ACTIVITY OF PHENYLHEPTATRIYNE}

A thesis submitted in partial fulfillment of the requirements for the degree of

MASTER OF SCIENCE

in

BIOLOGY

by

Rachel Arrasmith Gray 
To: Dean R. Bruce Dunlap

College of Arts and Sciences

This thesis, written by Rachel Arrasmith Gray, and entitled Cytotoxicity and Drug Potentiating Activity of Phenylheptatriyne, having been approved in respect to style and intellectual content, is referred to you for judgment.

We have read this thesis and recommend that it be approved.

Bradley C. Bennett

Sylvia L. Smith

Kelsey R. Downum, Major Professor

Date of Defense: October 18, 2004

The thesis of Rachel Arrasmith Gray is approved.

Dean R. Bruce Dunlap College of Arts and Sciences

Dean Douglas Wartzok University Graduate School

Florida International University, 2004 
C Copyright 2004 by Rachel Arrasmith Gray

All rights reserved. 


\section{DEDICATION}

I dedicate this thesis to my family. My "Ma," Joan, and Grandmother, Helen, would not let me give up. My Aunt, Arlene, gave me constant encouragement. My Dad, Ed, was always proud. My brothers, Zack and Matt, provided inspiration and kept me grounded. My sister-in-law, Lisa, and her beautiful daughter, Alyssa, who I am lucky to call my niece, showed me the strength a family can give you. 


\section{ACKNOWLEDGMENTS}

This thesis would not have been completed without the assistance and support of the following people. My committee members included Kelsey R. Downum, Bradley C. Bennett, and Sylvia L. Smith. They were always enthusiastic and willing to help. Their joint expertise in natural products, botany and immunology, respectively, proved invaluable. James G. Graham supervised and aided in the plant collection and phytochemistry lab work. For his dedication to the project and to my success, I am very grateful. The resources of and equipment in the Center for Ethnobiology and Natural Products (CENaP) at F.I.U. were essential for the completion of this project.

The bioassay portion of this project would not have been possible without the generosity and support of the folks at the Miami Children's Hospital Research Institute in Miami, Florida. Cheppail Ramachandran, Steven J. Melnick, and Stuart Horowitz, provided guidance and advice. I am grateful for the time Cheppail Ramachandran spent with me discussing scientific literature and data collection. Arturo Alamo trained me on the flow cytometer and answered many questions. His patience and kindness were incredible. Hugo Fonseca and Sonia Rodriguez helped me with cell culture and assay protocols. Raveendran Nair always had good advice and a great sense of humor.

The folks in the Chemistry Department at F.I.U analyzed the phytochemical samples. Alberto J. Sabucedo performed the GC-MS analyses. J. Martin Quirke and Myron Georgiadis in the Advanced Mass Spectrophotometry Facility aided in the data interpretation. 


\section{ABSTRACT OF THE THESIS \\ CYTOTOXICITY AND DRUG POTENTIATING ACTIVITY OF \\ PHENYLHEPTATRIYNE}

by

Rachel Arrasmith Gray

Florida International University, 2004

Miami, Florida

Professor Kelsey R. Downum, Major Professor

The purpose of this study was to determine the toxicity of the phototoxin, phenylheptatriyne (PHT) to acute lymphoblastic leukemia cells (ALL) under attenuated light conditions and when exposed to ultraviolet-A light (UVA). The potential of PHT to increase sensitivity of ALL cells to the anti-cancer drug doxorubicin hydrochloride also was evaluated. An in vitro multi-drug resistance model was used consisting of the parental cell line CCRF-CEM and its p-glycoprotein (pgp-170) expressing variant CEM/VLB 100 . Cytotoxicity was measured using the tetrazolium bromide (MTT) reduction assay and the annexin-V-FITC / propidium iodide (PI), flow cytometric assay. The results indicate that PHT is more toxic, when not photoexcited, to the CEM/VLB 100 cell line $(P=0.006)$. There was a significant interaction between UVA dose and PHT concentration $(\mathrm{P}<0.001)$. Co-incubation of $\mathrm{CEM} / \mathrm{VLB}_{100}$ cells with less than $10 \mu \mathrm{M}$ doxorubicin and $60 \mu \mathrm{M}$ PHT, significantly decreased viability relative to doxorubicin alone $(\mathrm{P}=0.007)$. 


\section{TABLE OF CONTENTS}

CHAPTER

PAGE

I. EXTRACTION AND PURIFICATION OF PHENYLHEPTATRIYNE FROM $B$. alba var. radiata (ASTERACEAE)

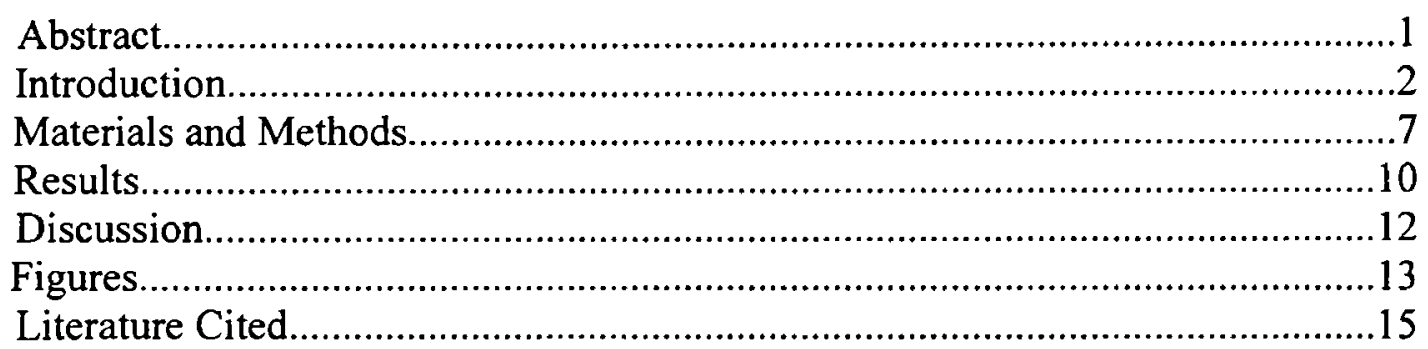

II. CYTOTOXICITY OF PHENYLHEPTATRIYNE FOR THE ACUTE LYMPHOBLASTIC LEUKEMIA CELL LINES, CCRF-CEM AND $\mathrm{CEM} / \mathrm{VLB}_{100}$

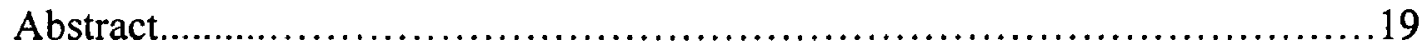

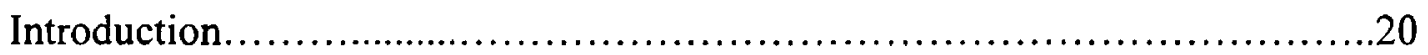

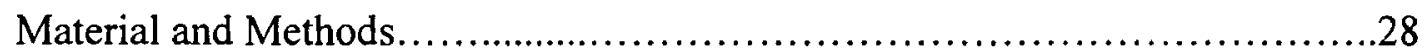

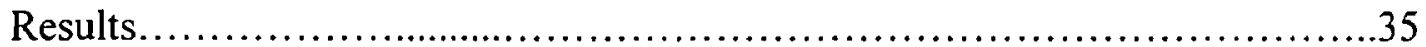

Discussion .................................................................... 41

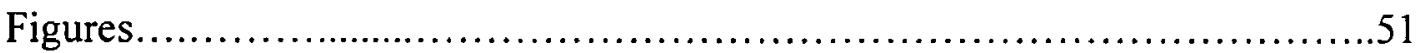

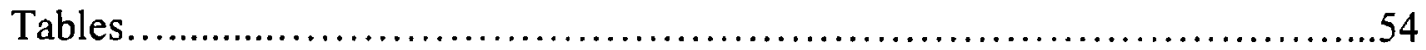

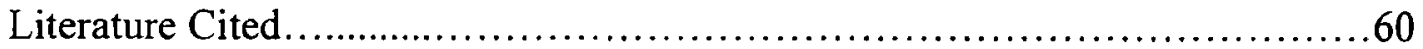

III. DRUG POTENTIATING ACTIVITY OF PHT IN THE MULTI-DRUG RESISTANT CELL LINE, CEM/VLB 100 .

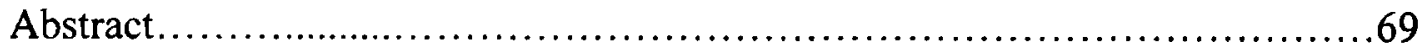

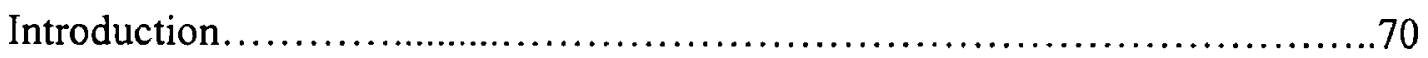

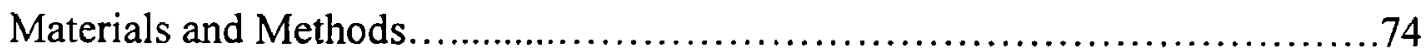

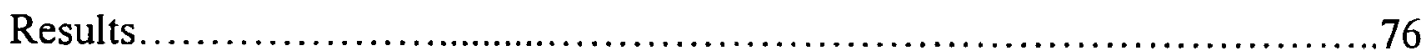

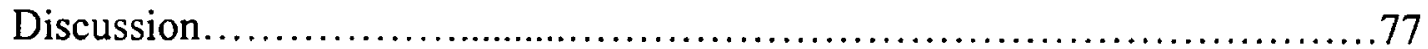

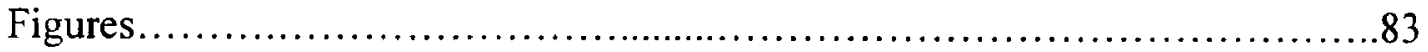

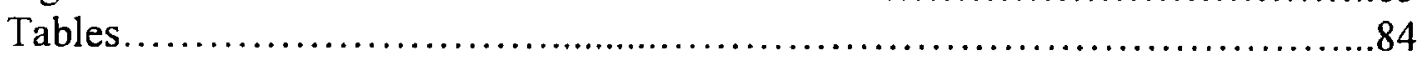

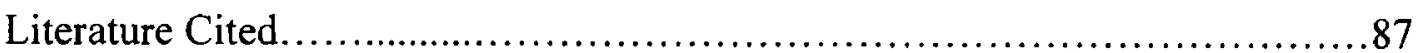




\section{LIST OF FIGURES}

FIGURE

PAGE

Chapter 1.

1. Ultraviolet electromagnetic absorbance spectrum of the purified PHT isolate.

2. Total ion chromatogram (TIC) and electron impact mass spectrum (EIMS) of the purified PHT isolate.

Chapter 2.

1. Structure of PHT.

2. Emission spectra of lamp used for UVA irradiation treatments.

3. Metabolic activity of CCRF-CEM cells after incubation with $B$. alba ethanolic extract.

4. Metabolic activity and membrane integrity of CCRF-CEM and

$\mathrm{CEM} \mathrm{VLB}_{100}$ cells after 24 hour incubation with PHT \pm UVA.

5. Membrane integrity of $C E M / V L B_{100}$ cells after 4 hour incubation with $\mathrm{PHT} \pm$ UVA irradiation.

6. Membrane integrity of $\mathrm{CEM} / \mathrm{VLB}_{100}$ cells after 24 hour incubation with $\mathrm{PHT} \pm$ UVA irradiation.

7. Membrane integrity of CCRF-CEM cells after 4 hour incubation with PHT \pm UVA irradiation.

8. Membrane integrity of CEM/VLB ${ }_{100}$ cells after 24 hour incubation with $\mathrm{PHT} \pm$ UVA irradiation.

Chapter 3.

1. Metabolic activity of CCRF-CEM and CEM/VLB ${ }_{100}$ cells after 48 hour incubation with PHT.

2. Metabolic activity of $C E M / V L B_{100}$ cells after 48 hour incubation with either Doxorubicin, or Doxorubicin $+60 \mu \mathrm{M}$ PHT. 


\section{LIST OF ABBREVIATIONS}

AA

$\mathrm{ABC}$

AML

ALL

ANOVA

APT

ATCC

ATP

CAT

$\mathrm{CH}_{2} \mathrm{CL}_{2}$

$\mathrm{C}_{2} \mathrm{H}_{3} \mathrm{~N}$

$\mathrm{C}_{3} \mathrm{H}_{6} \mathrm{O}$

CNS

$\operatorname{COX}$

CPA

$\mathrm{Cu} / \mathrm{ZnSOD}$

DHA

DNA

DOX

EPA
Arachidonic acid

ATP binding cassette

Acute myeloid leukemia

Acute Lymphoblastic Leukemia

Analysis of variance

Aminophospholipid translocase

American Type Culture Collection

Adenosine triphosphate

Catalase

Dichloromethane

Acetonitrile

Acetone

Central Nervous System

Cyclooxygenase

Cis-parinaric acid

Copper/Zinc superoxide dismutase

Docosahexaenoic acid

Deoxyribonucleic acid

Doxorubicin

Eicosapentaenoic acid 
ESR

ETC

FBS

FITC

GLA

GC-MS

GPx

GR

GSH

GST

$\mathrm{H}_{2} \mathrm{O}$

$\mathrm{H}_{2} \mathrm{O}_{2}$

HCL

HPLC

iNOS

LOOHs

MDR

MnSOD

MRP

MTT

$\mathrm{N}_{2}$

NAC

NDGA
Electron paramagnetic spin resonance

Electron transport chain

Fetal bovine serum

Fluorescein isothiocyanate

Gamma-linoleic acid

Gas Chromatography Mass Spectrometry

Glutathione peroxidase

Glutathione reductase

Glutathione

Glutathione- $S$-transferase

Water

Hydrogen peroxide

Hydrochloric acid

High Performance Liquid Chromatography

Inducible nitric oxide synthase

Lipid hydroperoxides

multi-drug resistant

Manganese superoxide dismutase

Multi-drug resistance protein

3-(4, 5-dimethylthiazol-2-yl)-2, 5-diphenyltetrazolium bromide

Nitrogen Gas

N-acetyl cysteine

Nordihydroguaiaretic acid 
Nitric oxide

ODS

Octadecylsilane

PAs

Polyacetylenes

PBS

Phosphate buffered saline

PGP

P-glycoprotein

PHA

Phytohemagluttinin

PHT

Phenylheptatriyne

PI

Propidium iodide

PS

Phosphatidylserine

PUFAs

Polyunsaturated fatty acids

RNA

Ribonucleic acid

ROI

Reactive oxygen intermediates

ROS

Reactive oxygen species

RP-TLC

Reversed Phase Thin Layer Chromatography

SE

Standard Error

SOD

Superoxide dismutase

TNF

Tumor necrosis factor

TLC

Thin Layer Chromatography

UV

ultraviolet 
EXTRACTION AND PURIFICATION OF PHENYLHEPTATRIYNE FROM

Bidens alba (L.) DC. var. radiata (Sch. Bip.) R.E. Ballard (ASTERACEAE)

\section{ABSTRACT}

The subtropical weed Bidens alba var. radiata (Sch. Bip) R.E. Ballard is rich in acetylenic compounds, most notably the potent phototoxin, phenylheptatriyne (PHT). Standards of PHT are not available on the market so it was first necessary to extract the compound from a botanical source. The purpose of this study was to extract and purify PHT from the leaves of $B$. alba and determine the percent (\%) yield of PHT from weight of fresh plant material extracted in $95 \%$ ethanol.

Flowering B. alba plants were collected during the month of March, 2003, from the South Florida Ecosystem Preserve at Florida International University (FIU) in Miami, Florida. Fresh plant material was extracted overnight in $95 \%$ ethanol, dried under vacuum, and partitioned between dichloromethane $\left(\mathrm{CH}_{2} \mathrm{CL}_{2}\right)$ and water $\left(\mathrm{H}_{2} \mathrm{O}\right)$. The organic partition was fractionated using normal phase flash chromatography with an ultraviolet (UV) detector.

Fractions with the characteristic UV spectra of polyacetylenes (PAs) were pooled and dried under nitrogen $\left(\mathrm{N}_{2}\right)$ gas. The PAs were further purified by extraction with $95 \%$ ethanol and subsequent separation using a reversed phase thin layer chromatography (RPTLC) system composed of $\mathrm{C}_{2} \mathrm{H}_{3} \mathrm{~N}$ (acetonitrile) and $\mathrm{H}_{2} \mathrm{O}$. The purity of isolated PHT was determined by gas chromatography-mass spectrometry (GC-MS). 


\section{INTRODUCTION}

While the role of Phenylheptatriyne (PHT) as a plant defense compound has been well established, (Camm et al., 1975; Towers et al., 1987; Downum et al., 1991), its bioactivity in mammalian systems is not well studied. PHT is a polyacetylene and a major component of some plant species in the Heliantheae tribe of Asteraceae. Bidens spp. are used extensively in traditional medical systems to treat symptoms of diabetes, the common cold and kidney and liver disorders (Cano et al., 2004; Simoes et al., 1999; Zamora-Martinez et al., 1992; Alice et al., 1991; Lin et al., 1990). Bidens spp. are sources of PHT and many other polyacetylenic compounds. In recent years, polyacetylenes (PAs) have been isolated as the anti-cancer and anti-inflammatory constituents of plant species used in traditional medicine (Matsunaga et al., 1990). Polyacetylenes are fatty acid derivatives and show activity comparable to their essential fatty acid precursors. For example, PAs modulate the redox status of cells, inhibit eicosanoid production and alter membrane composition. As such, they have the potential to interfere with the process of carcinogenesis or potentiate the action of certain anti-neoplastic drugs (Rose et al., 1999). In this study, for the effect of PHT on membrane integrity and metabolic activity of acute lymphoblastic leukemia cells (ALL) under controlled conditions of UVA irradiation was examined. Leukemia cell lines were chosen because organic and aqueous extracts of Bidens spp. have shown cytotoxicity to both murine and human leukemia cell lines but the specific constituents in these extracts responsible for the anti-leukemic activity have not been elucidated (Goun et al., 2002; Chang et al. 2001). 
In the first part of this study, I sought to extract and purify PHT and maximize percent yield for further bioassay work. This work is detailed below along with a brief review of the taxonomy, ethnomedical use, chemotaxonomy and bioactivity of Bidens spp.. It is hoped it will stimulate continued research into the potential medicinal use of plants in the genus Bidens.

\section{Taxonomy.}

Bidens alba var. radiata (L.) DC. is a variety of the pantropical annual weed, $B$. alba (Linnaeus) A. P. de Candolle (Asteraceae). The genus Bidens is in the subfamily Asteroideae, tribe Heliantheae and of the subtribe Coreopsidinae. Its range encompasses southern Florida, Cuba, the tropical lowlands and mountains along the eastern coast of Mexico, southward into Guatemala and Central America (Ballard, 1986). The species $B$. alba (L.) DC., according to Ballard, has two geographically overlapping varieties, $B$. alba var. radiata and $B$. alba var. alba., which are distinguished primarily by stem and leaf morphology. The stems of $B$. alba var. alba are decumbent, with glabrous leaves, while the stems of $B$. alba var. radiata are erect, with pubescent leaves.

Based on extensive field observations, examination of herbarium specimens, controlled greenhouse experiments, cytogenetic studies, leaf flavonoid analyses and hybridization studies, Ballard (1986) proposed the placement of the taxa in the Bidens pilosa complex, made up of three closely-related, exclusively neotropical species: $B$. alba, B. odorata and B. pilosa var. pilosa. The B. pilosa complex as proposed by Ballard was a systematic re-evaluation of the species $B$. pilosa L., sensu Sherff, which was hypothesized to contain six varieties-two of them pan-tropical. Ballard questioned the importance of the morphological characteristics used by Sherff (1937), such as leaf 
dissection and ray floret ligule color, to separate $B$. pilosa sensu lato Sherff into six varieties and many forms. Field and greenhouse observations showed these morphological variations to occur within a population and therefore cast doubt on the conclusions drawn by Sherff from sole study of herbarium voucher specimens.

Traditional Medicine.

There are numerous reports of the ethnomedical use of the species Bidens pilosa L. by traditional healers in Asia, Africa, South America, Central America, North America (Mexico, Hawaii), China and Taiwan for the treatment of acute and chronic inflammation, malaria and hepatitis. Zulus in South Africa chew the leaves of $B$. pilosa to treat headaches and inflammatory diseases (Jager et al., 1996) and traditional healers in Rwanda use the plant to treat infections and autoimmune disease (Cos et al., 2002). Peoples in Brazil, Peru, Mexico and Taiwan treat hepatitis with decoctions and infusions of the entire plants and the leaf juice of B. pilosa (Alice et al., 1991; Simoes et al., 1999; Zamora-Martinez et al., 1992; Lin et al., 1990). In Brazil and China the entire plant and leaf juice is used in external and internal anti-inflammatory and anti-malarial medicines (Krettli et al., 2001; Akah et al., 1995; Duke et al., 1985). Peoples in Tanzania and Rwanda use a preparation of the leaf and boiled root to treat malaria (Kokwar, 1976; Chhabra et al., 1994; Chagnon, 1984). The Haya in Tanzania wrap B. pilosa leaves in the leaves of bananas and roast them to a paste that is applied to wounds (Chhabra et al., 1994). 


\section{Chemotaxonomy.}

The polyacetylenic compounds of Bidens species are useful chemotaxonomic markers (Bohlmann, 1973; Christensen et al., 1991). The genera in the Heliantheae subtribe, Coreopsidinae of which Bidens is a member, show the greatest diversity of polyacetylenic compounds of all the subtribes. Restricted to the Heliantheae and characteristic of the Coreopsidinae are polyacetylenic compounds with phenyl groups on either end of the molecule or aromatic PAs (Bohlmann, 1973). It is proposed that the acetylenes found in the tribe Heliantheae are derived from $\mathrm{C}_{18}$ fatty acids in the sequence oleic acid to linoleic acid to crepenynic acid (Christensen et al., 1991). The $\mathrm{C}_{13}$ aromatic triynes are biosynthesized from $\mathrm{C}_{18}$ acetylenes by double $\beta$-oxidation followed by further oxidation steps and a ring closure. $\mathrm{A}_{18}$ - triyne fatty acid is formed by subsequent dehydrogenation or desaturation of oleic acid and the polyacetylenic fatty acid, crepenynic acid. Double $\beta$-oxidation of the $C_{18}$-triyne acid leads to the formation of a $C_{14}$ conjugated triyne-ol. The precursor of PHT is the polyacetylenic fatty acid, dehydrocrepenynic acid (Robinson, 1981).

\section{Bioactivity.}

Many species in the genus Bidens have been evaluated in in vitro and in vivo bioassays for anti-inflammatory, anti-malarial, anti-bacterial, anti-viral, anti-cancer, antidiabetic and anti-hypertensive activity. The aqueous whole plant extract of the $B$. pilosa inhibits the growth of leukemia cell lines in vitro and methanolic leaf extracts inhibit the phytohemagluttinin (PHA) stimulated proliferation of human lymphocytes in vitro, and the alternative and classical activity of complement (Chang et al., 2001; Pereira et al., 1999; Cos et al., 2001). In addition, the leaf ethanolic extract of $B$. pilosa inhibits 
cyclooxygenase (COX) activity and is significantly cytoprotective against indomethacin and ethanol-induced gastric lesions in rats (Jager et al., 1996; Tan et al., 2000). Leaf extracts of B. pilosa are also active against Mycobacterium tuberculosis (Van Puyvelde et al., 1994). Hot water extracts of $B$. pilosa inhibited the replication of Herpes simplex viruses Type I and Type II (Chiang et al., 2003). Aqueous ethanolic extracts of B. pilosa administered intraperitoneally, attenuated hyperglycemia in alloxan diabetic mice (Alarcon-Aguilar et al., 2002). B. pilosa extracts also attenuated fructose hypertension in Wistar rats by lowering blood pressure and preventing hyperinsulinemia (Dimo et al., 2002).

The acetylenic compounds typically found in Bidens spp. (Christensen et al., 1991) may be responsible for the efficacy of preparations and extracts. Brandão et al. (1997) have shown that the polyacetylenic constituents of B. pilosa extracts contribute to the inhibition of in vitro Plasmodium falciparum growth. PAs isolated from $B$. campylotheca are potent inhibitors of cyclooxygenase and lipoxygenase (5-LOX) activity (Redl et al., 1994). PHT isolated from B. pilosa contributed to the anthelmintic and protozoacidal activity of methanolic extracts in in vitro and in vivo murine models (N'Dounga et al., 1983). A mixture of acetylenic glucosides from B. pilosa decreased blood sugar levels in type-2 diabetes mice models (Ubillas et al., 2000).

Because of the taxonomic confusion associated with the taxon B. pilosa L., many accounts of the use of Bidens spp. in traditional medical systems, along with the attributed bioactivity data, should be reexamined. If vouchers specimens were not made, the possibility should be considered that any one of the species in the B. pilosa complex could have been the referenced, studied or chemically characterized specimen. This is 
more likely the case for plants collected in Mexico and Central America, but even possibly in northwestern Hong Kong where B. alba L. (DC) has been reported to occur in the wetlands around the Mai Po Marshes and is often confused with B. pilosa L. (Corlett, 1992).

\section{MATERIALS AND METHODS}

\section{Collection.}

Flowering Bidens alba var. radiata plants were collected from several sites within the South Florida Ecosystem Preserve on the main campus of Florida International University (FIU), Miami, Florida. Whole plants were harvested, including the above ground parts and roots. A voucher was prepared for deposit in the Fairchild Tropical Garden (FTG) herbarium. The collection number is Graham and Gray \# 2831. The fresh plant material was brought to the laboratory immediately upon collection. Five samples were prepared; one consisting of the entire plant, and others made up of fresh inflorescences, leaves, stems and root material. They were immediately extracted following the method described below.

Chemicals and chromatography supplies.

The solvents used for purification and isolation procedures included HPLC grade dichloromethane (Acros, New Jersey, cat. \# 61005-0040), HPLC grade acetone (Acros, New Jersey, cat. \# 26831-0040), and Optima grade acetonitrile, (Fisher Scientific, Suwanee, GA, cat. \# A9964). Chromatography procedures were performed using RediSep $^{\mathrm{TM}}$ normal phase silica gel columns (Isco, Lincoln, NE, cat. \# 68-2203-027), and 
octadecylsilane binded $\left(\mathrm{PLKC}_{18}\right)$ preparative thin layer chromatography (TLC) plates (Whatman Maidstone, England cat. \# 4800-840).

Extraction procedure and percent yield.

The fresh plant parts were weighed and then homogenized in $95 \%$ ethanol, at a ratio of 10 grams of plant material for each $100 \mathrm{ml}$ of ethanol, in a commercial blender. After 24 hours, the extracts were vacuum filtered through Whatman filter paper (No.1) and concentrated using a rotary evaporator. The water bath temperature was maintained at a constant temperature of $30^{\circ} \mathrm{C}$ in order to prevent decomposition of heat sensitive acetylenic constituents. If samples still contained water after evaporation, they were lyophilized.

The bulk of the crude samples were partitioned between $\mathrm{CH}_{2} \mathrm{CL}_{2}$ and $\mathrm{H}_{2} \mathrm{O}$, to yield organic and aqueous partitions, while a small amount of the crude, dried ethanolic extracts were retained for subsequent bioassay and spectrometric analyses. Stock and bioassay samples were stored at $-20^{\circ} \mathrm{C}$ in amber vials or wrapped in aluminum foil to protect from heat and light.

To purify and determine the percent yield of PHT obtained by this method, 500 grams of fresh leaf material were extracted as described above. The dried residue of the organic partition was weighed and then $1 / 15$ th, or $500 \mathrm{mg}$, of this residue was subjected to the purification procedure described below. The percent yield was calculated by multiplying the mass of the purified PHT by 15 and then dividing by the original mass of fresh leaves extracted (500 grams) and multiplying by 100 . 


\section{Isolation and purification of Phenylheptatriyne.}

PHT was isolated from the crude ethanolic extract of fresh $B$. alba leaves by first partitioning the dried extract between $\mathrm{CH}_{2} \mathrm{CL}_{2}$ and $\mathrm{H}_{2} \mathrm{O}$. The $\mathrm{CH}_{2} \mathrm{CL}_{2}$ partition was then fractionated using the ISCO CombiFlash, flash chromatography system, equipped with a $210 \mathrm{~nm}$ UV absorbance detector. A RediSep ${ }^{\mathrm{TM}}$ normal phase silica gel column was used that contained 40 grams normal phase silica gel of 35-60 micron $(\mu \mathrm{m})$ particle size (230400 mesh). A $500 \mathrm{mg}$ sample solubilized in $3 \mathrm{ml} \mathrm{CH}_{2} \mathrm{CL}_{2}$ was run through a solvent system composed of $\mathrm{CH}_{2} \mathrm{CL}_{2}$ and $\mathrm{C}_{3} \mathrm{H}_{6} \mathrm{O}$ (acetone). The method used was an initial isocratic gradient with $100 \% \mathrm{CH}_{2} \mathrm{CL}_{2}$ held constant over 4 minutes and then a linear gradient with 100:0 - 0:100, $\mathrm{CH}_{2} \mathrm{CL}_{2}$ to $\mathrm{C}_{3} \mathrm{H}_{6} \mathrm{O}$ over 16 minutes for a total run time of 20 minutes. The flow rate was set at $25 \mathrm{ml} / \mathrm{min}$.

The fractions containing PAs were identified using an Agilent 8453 UV-Visible ChemStation equipped with a tungsten and deuterium lamp. The first fraction to elute from the RediSep ${ }^{\mathrm{TM}}$ normal phase silica gel column had the characteristic UV absorbance

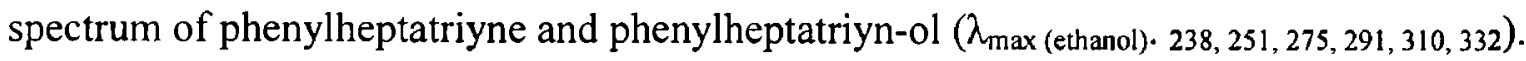
The PA containing fraction was oily, orange colored and fragrant. This fraction also showed a strong absorbance in the $400-500 \mathrm{~nm}$ region. The fraction was dried under nitrogen at room temperature and then further extracted in $95 \%$ ethanol and filtered through Whatman filter paper (No.1). The sample was then run through a RP-TLC system consisting of a $\mathrm{C}_{18}$ octadecylsilane (ODS) stationary phase with a $\mathrm{UV}_{254}$ fluorescent indicator and a mobile phase composed of $\mathrm{C}_{2} \mathrm{H}_{3} \mathrm{~N}_{\mathrm{N}} \mathrm{H}_{2} \mathrm{O}(85: 15)$. The PHT fraction was detected by quenched fluorescence. This fraction was scraped from the TLC 
plate and extracted in $95 \%$ ethanol and then concentrated under $\mathrm{N}_{2}$ gas. Molar concentration of PHT was determined using ultraviolet/visible spectrophotometry (UV/VIS). The molar extinction coefficient used was $148,000 \mathrm{M}^{-1} \mathrm{CM}^{-1}\left(\varepsilon_{251 \mathrm{~nm}}\right)$. The molecular weight of PHT is 164 grams.

\section{Purity determination.}

Purity of the isolated product was determined by coupled gas chromatographymass spectrometry (GC-MS). Analysis was performed using a Hewlett Packard (HP) 6890 series GC system equipped with a HP5973 mass selective detector. Five $\mu \mathrm{L}$ of a 20 mM solution was introduced onto a HP-5MS $5 \%$ phenyl methyl siloxane capillary column $(30.0 \mathrm{~m} \times 0.25 \mathrm{~mm}$ ID, film thickness $0.25 \mu \mathrm{m})$ through an injection port with a split ratio of $10: 1$, injection temperature $280^{\circ} \mathrm{C}$. The initial temperature on the column was $100^{\circ} \mathrm{C}$ for 1.00 minute, which was then increased by $20^{\circ} \mathrm{C} /$ minute to a final temperature of $280^{\circ} \mathrm{C}$ with a run time of 12.00 minutes, and a helium flow rate through the column at $1 \mathrm{ml} / \mathrm{min}$. Mass detection took place over a scan range of 33-450 atomic mass units (a.m.u). The sample was analyzed in the Advanced Mass Spectrometry Facility in the Department of Chemistry and Biochemistry at F.I.U.

\section{RESULTS}

Percent yield.

From 500 grams of fresh leaf material harvested from mature plants and extracted at room temperature in $95 \%$ ethanol, a residue with a mass of 17.84 grams was obtained. This residue was partitioned between $\mathrm{CH}_{2} \mathrm{CL}_{2}$ and $\mathrm{H}_{2} \mathrm{O}$ and the organic partition yielded 
7.584 grams. A $500 \mathrm{mg}$ sample of the dried organic partition was then run through the normal phase chromatography system described under Materials and Methods. The first fraction to elute from the column had a mass of $29.2 \mathrm{mg}$ when dried under $\mathrm{N}_{2}$ gas. A PHT sample was obtained after the subsequent run through a RP-TLC system, which had a mass of $2.9 \mathrm{mg}$ when dried. Because the sample run through RP-TLC represented 1/15th of the organic partition, the total amount of PHT isolated from 500 grams fresh leaf material was calculated as $43.5 \mathrm{mg}$. The percent yield by this method was thus $0.0087 \%$ PHT.

\section{Isolation and purification of PHT.}

A fraction containing PHT was obtained using a normal phase flash chromatography system consisting of a silica gel column and a solvent system composed of $\mathrm{C}_{2} \mathrm{H}_{3} \mathrm{~N}$ and $\mathrm{C}_{3} \mathrm{H}_{6} \mathrm{O}$. The first fraction to elute from the column had the characteristic polyacetylenic spectra of phenylheptatriyne and phenylheptatriyn-ol and also showed uncharacteristic absorbance in the $400-500 \mathrm{~nm}$ region. Further purification with $\mathrm{C}_{18} \mathrm{RP}$ TLC and 85:15 (acetonitrile: water), yielded a colorless polyacetylene with the

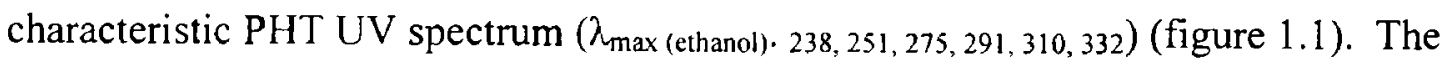
fraction had a retention factor (Rf) of 0.46 in this system.

\section{Purity determination.}

The PHT isolate was analyzed by GC-MS. The total ion chromatogram of the isolate showed the presence of a single peak at a mass to charge ratio $(\mathrm{m} / \mathrm{z})$ of 164 (figure 1.2). This indicates that the isolate was of the same molecular mass as PHT and of considerable purity. 


\section{DISCUSSION}

PHT was first isolated by Sörensen et al. (1958) from Coreopsis grandiflora Hogg ex Sweet. Because PAs are thermally unstable, a PHT standard is not available. For this reason it was necessary to isolate and purify PHT from the leaves of $B$. alba var. radiata. By the methods used in this study, a PHT sample of considerable purity was obtained. PAs are found in Asteraceae species at $0.1 \%$ or less (McLachlan et al., 1986). My calculations show the percent yield of PHT from a $95 \%$ ethanolic extract of fresh $B$. alba var. radiata leaf material to be $0.0087 \%$. Wat et al. (1979) found PHT to be present as $400-600 \mu \mathrm{g} / \mathrm{g}$ of $B$. pilosa $\mathrm{L}$. fresh weight or as much as $0.04-0.06 \%$.

Cantonwine et al. (2001) reported PHT concentration in B. alba var. radiata to vary seasonally across its Florida range, being highest in October and lowest in January and April. The percent yield of PHT obtained from fresh leaves of this plant species collected in the fall should also be determined using this method. It is possible that the greatest percent yield of PHT could be obtained from plants collected in the fall months. 
Figure 1.1. Ultraviolet electromagnetic absorbance spectrum of the purified PHT isolate. The sample was solubilized in $95 \%$ ethanol and analyzed with an Agilent $8453 \mathrm{UV}$ Visible ChemStation equipped with a tungsten and deuterium lamp. Below is the UV absorbance spectrum from $220-400 \mathrm{~nm}$ of a $10 \mu \mathrm{M}$ solution of PHT.

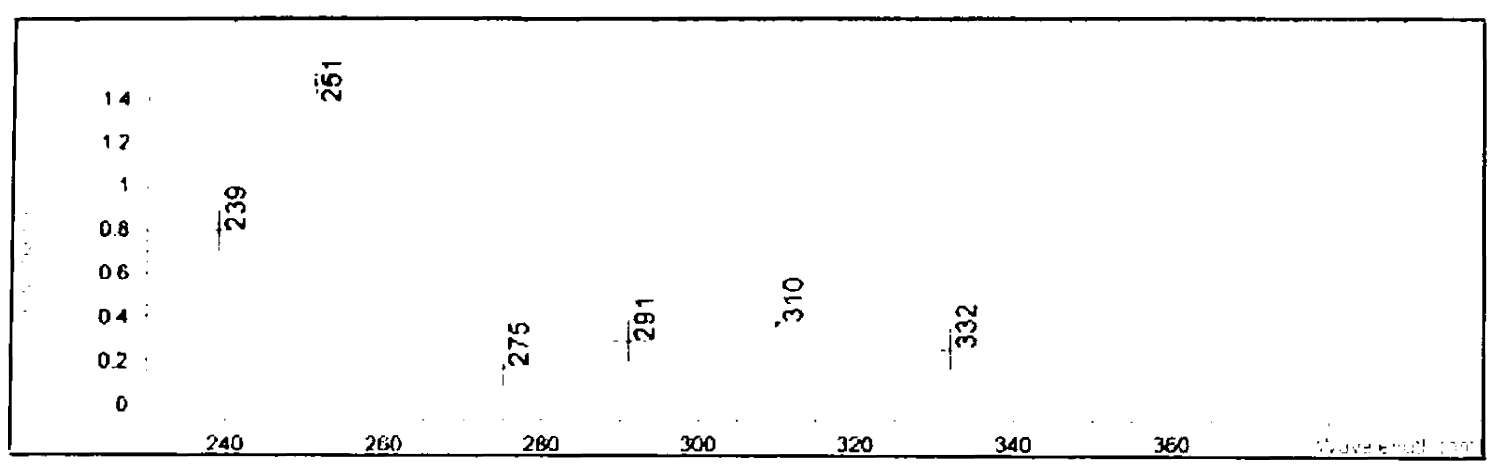


Figure 1.2. Total Ion Chromatogram (TIC) (A) and Electron Impact Mass Spectrum (EIMS) (B) of the purified PHT isolate.

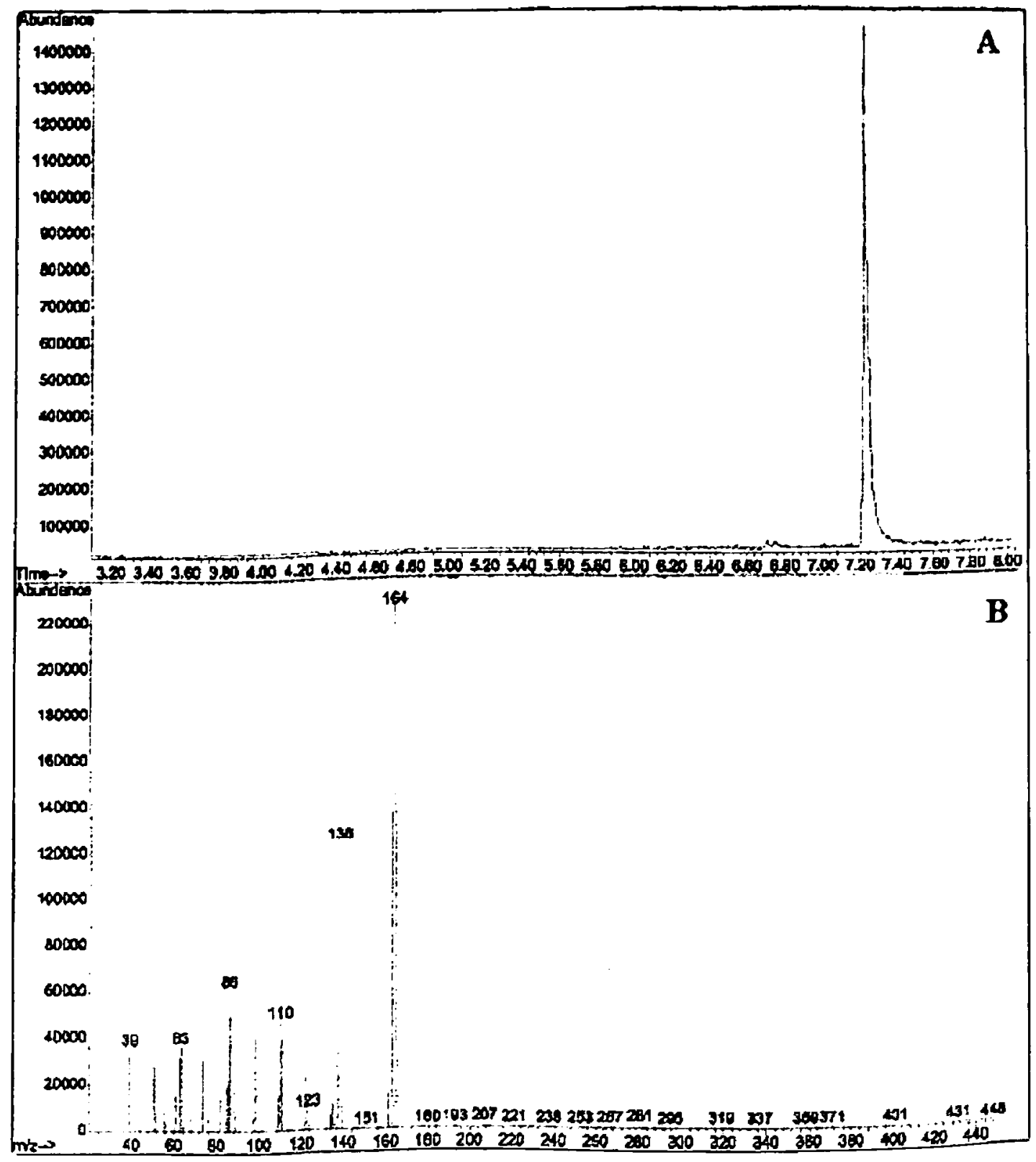




\section{LITERATURE CITED}

Alarcon-Aguilar FJ, Roman-Ramos R, Flores-Saenz JL, Aguirre-Garcia

F.2002.Investigation on the hypoglycaemic effects of extracts of four Mexican medicinal plants in normal and alloxan-diabetic mice. Phytother Res 16:383-386.

Alice CB, Vargas VMF. Silva GAAB, De Siqueria NCS, Schapoval EES, Gleve J, Henriques JAP, Henriques AT.1991.Screening of plants used in South Brazilian folk medicine. J Ethnopharmacol 35:165-171.

Akah PA, Ekekwe RK.1995.Ethnopharmacology of some Asteraceae family used in Nigerian traditional medicine. Fitoterapia 66:266-272.

Ballard R. 1986. Bidens pilosa complex (Asteraceae) in North and Central America. Am J Bot. 73: 1452-1465.

Bohlmann FT. Burkhardt T, Zdero C.1973. Naturally Occurring Acetylenes. Academic Press, London.

Brandão MGL, Krettli AU, Soares LSR, Nery CGC, Marinuzzi HC.1997. Antimalarial activity of extracts and fractions from Bidens pilosa and other Bidens species (Asteraceae) correlated with the presence of acetylene and flavonoid compounds. J Ethnopharmacol 57:131-138.

Camm EL, Towers GH, Mitchell JC.1975. UV-mediated antibiotic activity of some Compositae species. Phytochemistry 14:2007-2011.

Cano JH. Volpato G.2004. Herbal mixtures in the traditional medicine of Eastern Cuba. Journal of Ethnopharmacology. 90:293-316.

Cantonwine EG. Downum KR.2001. Phenylheptatriyne variation in Bidens alba var. radiata leaves. J Chem Ecol 27:313-326.

Chagnon M.1984. General pharmacologic inventory of medicinal plants of Rwanda. J Ethnopharmacol 12:239-251.

Chang JS, Chiang LC, Chen CC, Liu LT, Wang KC, Lin CC.2001. Antileukemic activity of Bidens pilosa L. var. minor (Blume) Sherff and Houttuynia cordata Thunb. Am J Chinese Med. 29:303-312.

Chhabra SC. Mahunnah RLA.1994. Plants used in traditional medicine by Hayas in the Kagera Region. Tanzania. Econ Bot 48:121-129. 
Chiang LC, Chang JS, Chen CC, Ng LT, Lin CC.2003. Anti-Herpes simplex virus activity of Bidens pilosa and Houttuynia cordata. Am J Chinese Med. 31:355362.

Christensen LP, Lam J.1991. Acetylenes and related compounds in Heliantheae. Phytochemistry 30:1 1-49.

Corlett RT.1992.Taxonomic notes on some common Hong Kong Weeds. Memoirs of the Hong Kong Natural History Society 19:136.

Cos P, Hermans N., Van Poel B., De Bruyne T, Apers S, Sindambiwe JB, Vanden Berghe D, Pieters L, Vlietinck AJ.2002.Complement modulating activity of Rwandan medicinal plants. Phytomedicine 9:56-61.

Dimo T, Rakotonirina S, Tan PV, Azay J, Dongo E, Cros G.2002. Leaf methanol extract of Bidens pilosa prevents and attenuates the hypertension induced by highfructose diet in Wistar rats. J Ethnopharmacol 83:183-191.

Downum KR, Swain LA, Faleiro LJ.1991. Influence of light on plant allelochemicals: a synergistic defense in higher plants. Arch Insect Biochem 17:201-211.

Duke JA, Ayensu ES.1985. Medicinal plants of China. Reference Publications, INC. 1:52-361.

Goun EA, Petrichenko VM, Solodnikov SU, Suhinia TV, Kline MA, Cunningham G, Nguyen C, Miles H.2002.Anticancer and antithrombin activity of Russian plants. Journal of Ethnopharmacology 81:337-342.

Jager AK, Hutchings A, van Staden J.1996.Screening of Zulu medicinal plants for prostaglandin-synthesis inhibitors. J Ethnopharmacol 52:95-100.

Judd WS, Cambell CS, Kellogg EA, Stevens PF, Donoghue MJ.2002.Plant Systematics: A Phylogenetic Approach. Sinauer Associates, Sunderland, MA.

Kagan J.1987.Phenylheptatriyne: occurrence, synthesis, biological properties, and environmental concerns. Chemosphere 16:2405-2416.

Kokwar J.1976.Medicinal plants of East Africa. East African Literature Review. Dept. of botany, Nairobi University, Nairobi, Kenya.

Krettli AU, Brandão MGL. Ferrari WMS.2001. New antimalarial drugs: a search based on plants in popular medicine to treat fever and malaria. Folha Med 120:119-126.

Lin, CC, Kan WS.1990. Medicinal plants used for the treatment of hepatitis in Taiwan. Am J Chinese Med. 18:35-43. 
Matsunaga H, Katano M, Yamamoto H, Fujito H, Mori M, Takata K.1990. Cytotoxic activity of polyacetylene compounds in Panax ginseng C. A. Meyer. Chem Pharm Bull 38:3480-3482.

McLachlan D, Arnason T, Lam J.1986. Structure-function relationships in the phototoxicity of acetylenes from Asteraceae. Biochem Syst Ecol. 14:17-23.

N'Dounga M, Balansard G, Babadjamian A, David PT, Gasquet M.1983. Study on Bidens pilosa $\mathrm{L}$. Identification and antiparasitic activity of 1-phenyl-1,3,5heptatriyne. Plantes Medicinales et Phytotherapie 17:64-75.

Pereira RLC, Ibrahim T, Lucchetti L, da Silva AJR, Goncalves de Moraes VL.1999.Immunosuppressive and anti-inflammatory effects of methanolic extract and the polyacetylene isolated from Bidens pilosa $\mathrm{L}$. Immunopharmacology 43:31-37.

Redl K. Breu W, Davis B. Bauer R.1994.Anti-inflammatory active polyacetylenes from Bidens campylotheca. Planta Med 60:58-62.

Robinson H.1981. A revision of the tribal and subtribal limits of the Heliantheae (Asteraceae). Smithsonian Contribution to Botany Number 51.

Rose DP, Connolly JM.1999.Omega-3 fatty acids as cancer chemopreventive agents. Pharmacol Therapeut 83:217-244.

Simoes CMO, Falkenberg M, Aulermentz L, Schenkel EP, Amoros M, Girre L.1999. Antiviral activity of South Brazilian medicinal plant extracts. Phytomedicine 6:205-214.

Sörensen JS, Sörensen NA.1958. Naturally occurring acetylene compounds. XXIII. 1Phenylheptatriyne from Coreopsis grandiflora. Acta Chem Scand 12:765-770.

Tan PV, Dimo T, Dongo E.2000.Effects of methanol, cyclohexane and methylene chloride extracts of Bidens pilosa on various gastric ulcer models in rats. $\mathrm{J}$ Ethnopharmacol 73:415-421.

Towers GHN, Hudson JB. 1987. Potentially useful antimicrobial and antiviral phototoxins from plants. Photochem Photobiol 46:61-66.

Lbillas RP. Mendez CD. Chivanand D. Luo J, King SR, Carlson TJ, Fort DM.2000.Antihyperglycemic acetylenic glucosides from Bidens pilosa L. Planta Med 66:82-83. 
Van Puyvelde L, Ntawukiliyayo JD, Portaels F, Hakizamungu E.1994. In vitro inhibition of mycobacteria by Rwandese medicinal plants. Phytother Res 8:65-69.

Wat CK, Biswas RK, Graham EA, Bohm L, Towers GH, Waygood ER.1979.Ultravioletmediated cytotoxic activity of phenylheptatriyne from Bidens pilosa. J Nat Prod 42:102-111.

Zamora-Martinez MC, Pola CNP.1992. Medicinal plants used in some rural populations of Oaxaca, Puebla and Veracruz, Mexico. J Ethnopharmacol 35:229-257. 


\title{
CYTOTOXICITY OF PHENYLHEPTATRIYNE (PHT) IN A MULTIDRUG RESISTANT (MDR) ACUTE LYMPHOBLASTIC LEUKEMIA CELL MODEL
}

\begin{abstract}
The purpose of this study was to compare the cytotoxicity of the phototoxin phenylheptatriyne (PHT) in the presence and absence of light excitation in a multi-drug resistant (MDR) acute lymphoblastoid leukemia (ALL) cell model. Cytotoxicity was assessed by measurement of changes in the asymmetry and integrity of the plasma cell membrane and the metabolic activity of cells using quantitative flow cytometric and colorimetric assays, respectively. The externalization of phosphatidylserine (PS), a marker of loss of phospholipid asymmetry, and the breakdown of plasma membrane integrity, were monitored in cells at 4 and 24 hours after exposure to PHT, using a dual parameter flow cytometric assay with the fluorochromes annexin -V- fluorescein isothiocyanate (FITC) and propidium iodide (PI). The tetrazolium bromide (MTT) reduction assay was used to determine the viability of cells after incubation with PHT for 24 hours. For both assays, cells were irradiated with controlled doses of UVA light, 1 hour into the incubation period.
\end{abstract}

The MDR, CEM/VLB 100 cell line was more sensitive to the toxicity of PHT, in the absence of light excitation, at the highest PHT concentrations tested, as assessed by the MTT assay. Results obtained from the annexin-V-FITC/ PI staining showed a considerable interaction between light level and concentration in both cell lines $(\mathrm{P}<$ 0.005). After 4 hours, a complete loss in membrane integrity was observed at the greatest PHT $\times$ UVA combinations only. In addition, a considerable time-dependent effect on membrane asymmetry and integrity was observed without photo-excitation, only in the 
CEM/VLB ${ }_{100}$ cell populations $(\mathrm{P}=0.040)$. Furthermore, the minimum PHT concentration required to produce phototoxic effects was lower for the CEM/VLB 100 populations than the CCRF-CEM populations.

Further work should involve elucidating the mechanism of toxicity of PHT in cancer cell lines with defined levels of detoxifying enzyme expression and in the presence of exogenous antioxidants. In addition, the loss of membrane asymmetry should be monitored simultaneously with events associated with apoptosis induction including cell shrinkage, membrane blebbing, chromatin condensation and nuclear fragmentation. These results can then be compared with measurements of cell necrosis, such as increases in cell volume and rupture or lysis of the cell membrane and associated rapid ATP depletion.

\section{INTRODUCTION}

PHT is a polyacetylenic fatty acid derivative characteristic of plant species in the genus Bidens of the Asteraceae (Downum, 1992). The phototoxicity of PHT has been established in animal viruses, bacteria, fungi, nematodes, insects and human fibroblast cells (Wat et al., 1979; Arnason et al., 1980; Hudson et al., 1982; McRae et al., 1985; Towers et al., 1987). Upon photoexcitation with UVA light, lipid peroxidation products are formed in liposomal models and enveloped (membrane-bound) DNA and RNA viruses are deactivated (McRae et al., 1985; Hudson et al., 1982; Hudson et al., 1986). Under the current model of PHT phototoxicity, the compound transfers excitation energy to oxygen to form singlet oxygen $\left(\mathrm{O}_{2}\right)$ that reacts with the lipid and protein components of biological membranes to cause the oxidation of sterol and polyunsaturated fatty acids (PUFAs). PHT is a lipophilic, rigid and linear molecule that intercalates cellular 
membranes and modulates permeability and it has been speculated that under attenuated light conditions, it may directly or indirectly alter the conformation of membrane proteins (McRae et al., 1985).

PAs have phototoxic activity if the structure contains a minimum of 3 conjugated acetylenic bonds or at least 2 aromatic rings. The phototoxic reactions are powered by photon energy absorbed by extensive pi electron systems (McLachlan et al., 1986; Downum, 1992). Compounds with both cyclic and acyclic moieties need 2 or more conjugated acetylenic bonds to be phototoxic (Downum, 1992). The hybrid phototoxin, (PHT) has 3-conjugated acetylenic bonds and is conjugated to an aromatic ring (1phenylhepta $-1,3,5$-triyne).

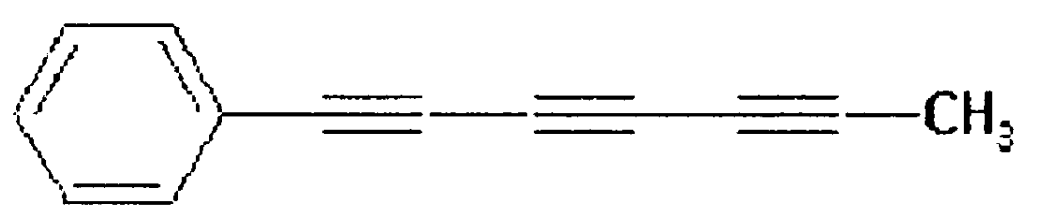

1-phenylhepta-1, 3, 5-triyne (PHT)

Figure 2.1. Chemical structure of PHT.

PAs are bioactive both in the presence and absence of light excitation. Their dark mediated activity is similar to that reported for polyunsaturated fatty acids (PUFAs). PUFAs are also phototoxic though they are excited by UVB irradiation as opposed to UVA irradiation (Arita et al., 2003). PAs cytotoxic to cancer cell lines have been isolated from the marine sponge, Pellinia triangulata Desqueyroux-Faundez (Oceanapiidae), the stony coral genus Montipora (Acroporidae) and the medicinal plants, Panax ginseng C.A. Meyer (Araliaceae), Adenia gummifera (Harv.) Harms (Passifloraceae), Gymnaster koraiensis (Nakai) Kitamura (Asteraceae), and 
Ochanostachys amentacea Mast. (Olacaceae) (Dai et al., 1996; Fullas et al., 1995; Alam et al., 2001; Jung et al., 2002; Ito et al., 2001).

PAs may have multiple roles as anti-proliferative, immunosuppressive and anticarcinogenic or cancer chemopreventive agents. They inhibit the production of nitric oxide (NO) though the inhibition of inducible nitric oxide synthase (iNOS) expression (Choi et al., 2000) which suggests a possible immunosuppressive and cytoprotective affect because host cells kill pathogens with NO and NO may kill cells by energydepletion-induced necrosis (Brown et al., 2002). NO can inhibit mitochondrial respiration thereby inducing necrosis (or excitotoxicity in neurons) but inhibit apoptosis through adenosine triphosphate (ATP) depletion. In fact, the polyacetylenic alcohol, panaxynol, isolated from Panax ginseng is toxic to cancer cells but promotes neuritogenesis of cultured neurons and improves scopolamine-induced memory deficit in mice (Yamazaki et al., 2001). Immunosuppressive activity is further supported by the anti-proliferative effect of PAs from Bidens pilosa in phytohemagglutinin (PHA) stimulated human lymphocytes in vitro and anti-inflammatory activity in in vivo murine models (Pereira et al., 1999). In addition, PAs with in vitro inhibitory activity against the classical pathway of the complement system were isolated from Dendropanax morbifera Leveille (Araliaceae) (Park et al., 2004).

Anti-proliferative agents with the dual action of inhibiting the production of NO and eicosanoid production have shown both cancer preventive and apoptosis inducing activity (Narayanan et al., 2004). Cyclooxygenase enzymes catalyze the conversion of arachidonic acid to prostaglandins. The overexpression of the cyclooxygenase 2 isoform (COX-2) is implicated in the pathogenesis of malignancies, including lung cancer and 
mammary cancer. COX-2 is overexpressed in many non-small cell lung cancer cases and COX-2 inhibitors chemosensitized COX-2 overexpressing lung cancer cell lines and potentiated the effect of radiation (Saha et al., 2003). The polyunsaturated fatty acids (PUFAs), eicosapentaenoic acid (EPA), docosahexaenoic acid (DHA), arachidonic acid (AA) and $c i s$-parinaric acid (CPA) potentiated the cytotoxicity of $\gamma$-irradiation in HL-60 cells. Omega-3 fatty acids inhibited the growth of breast cancer cells in culture and mammary carcinogenesis that was associated with their ability to diminish production of COX-2 (Stoll, 2002). Omega-3 fatty acids also induced apoptosis in HL-60 cells characterized by DNA fragmentation, and activation of the caspase cascade and was associated with increased generation of reactive oxygen species (ROS) and depolarization of the mitochondrial membrane (Kayo et al., 2001).

PAs have not been investigated for their ability to induce apoptosis though they are potent inhibitors of (lipoxygenase) 5-LOX and COX and interfere with the production of NO. Liu et al. (1998) investigated Angelica sp. (Apiaceae) for 5-LOX inhibition and found the most active compounds to be linoleic acid and two PAs, including the compound falcarindiol. Falcarindiol is also an anti-proliferative agent. It is produced in the Apiaceae and Araliaceae (Ginseng family) and was isolated from the roots of Heracleum moellendorffii Hance (Apiaceae) and Dendropanax arboreus (L.) Decne. \& Planch (Araliaceae). It was cytotoxic to tumor cell lines in vitro, by MTT reduction and in vivo, in a LOX melanoma mouse xenograft model (Nakano et al. 1998; Bernart et al. 1996). PAs isolated from Bidens campylotheca Sch. Bip. inhibited COX and 5-LOX (Redl et al., 1994). A PA isolated from Angelica gigas Nakai inhibited the production of NO in a lipopolysaccaride activated murine macrophage cell line (Choi et al., 2000). 
Polyacetylene glucosides isolated from Bidens parviflora Willd. inhibited NO production in lipopolysaccharide and interferon- $\gamma$ stimulated RAW 264.7 murine macrophages (Wang et al., 2001).

Many reports suggest 5-LOX and COX inhibitors to have the ability to induce apoptosis. The LOX inhibitor nordihydroguaiaretic acid (NDGA) induced apoptosis characterized by mitochondrial membrane depolarization, release of cytochrome- $c$ from mitochondria and activation of caspase-3 (Vondráček et al., 2001). Indomethacin induced apoptosis, in both COX-2 overexpressing and non-expressing, non-small cell lung cancer cell lines associated with cytochrome- $c$ release, caspase activation, chromatin condensation and nuclear fragmentation (Sánchez-Alcázar et al., 2003). NDGA induced apoptosis in a murine prolymphoid progenitor cell line that was attenuated by the nonenzymatic antioxidant defenses, glutathione (GSH) and N-acetylcysteine (NAC) (La et al., 2003). Interestingly, NDGA is also a phototoxin that generates ROS when excited by light (Downum, 1992).

As a phototoxin and fatty acid derivative, PHT may induce apoptosis that is associated with the formation of ROS and lipid peroxide end products (Das, 1999). Many anti-cancer agents induce apoptosis by modulating the redox status of cells or inducing oxidative stress (Yamaguchi et al., 1994; Hedley et al., 1998). Generation of ROS may occur as part of the final common pathway resulting in apoptosis after exposure to the cytokine tumor necrosis factor - alpha (TNF- $\alpha$ ), growth factor withdrawal, and different pro-oxidants, including anticancer agents such as doxorubicin (Tyurina et al., 2002). There may be many different upstream signaling pathways that can lead to the induction of apoptosis and the response of a cell to an upstream trigger 
may depend on its intracellular redox balance (Hedley et al., 1998; Öllinger et al., 2002). The antioxidant defense systems of cells can act at any stage in carcinogenesis and protect DNA from oxidative damage, but they may also have the paradoxical effect of protecting cancer cells from apoptosis involving oxidative stress and thus aid in their proliferation (Anderson, 1996; Ruiz et al., 2002). For example, when expression of manganese superoxide dismutase (MnSOD) is upregulated, cytotoxicity caused by ROS, TNF- $\alpha$ and ionizing radiation is inhibited (Cobbs et al., 1996).

The cytotoxicity of fatty acids and photoexcited PHT is inhibited in systems enriched with certain enzymatic and nonenzymatic antioxidants (Das, 1999; Aucoin et al., 1995). PHT phototoxicity is inhibited by increased superoxide dismutase (SOD) activity and exogenous $\alpha$-tocopherol and $\beta$-carotene (Aucoin et al., 1995). Insects that specialize on phototoxic host plants possess high constitutive levels of the lipid soluble antioxidants but also over-express enzymes involved in the detoxification of highly reactive, oxygen species. These include superoxide dismutase (SOD), catalase (CAT), glutathione reductase (GR), and increased levels of reduced GSH. If GSH is inhibited, insects fed PHT and irradiated with UVA show effects of lipid peroxidation. Ascorbate and $\alpha$-tocopherol attenuated arachidonic acid-induced cytotoxicity (Pompeia et al., 2002). Moreover, the high susceptibility of lymphoid leukemias to PUFA-induced toxicity is associated with reduced activity of glutathione-S-transferase (GST) and greater production of lipid peroxidation end products in comparison to normal lymphocytes (Anel et al., 2002).

PHT may thus show selective toxicity in the presence and absence of light excitation that may be dependent on the antioxidant defenses of the cell model under 
study. A cell that is under oxidative stress may die by apoptosis or necrosis, depending on the degree of insult (Buttke et al., 1994). A biphasic effect may be observed with cells dying by apoptosis or necrosis depending on the PHT concentration and UVA irradiation dose. Treatment of cells with prooxidants, hydrogen peroxide $\left(\mathrm{H}_{2} \mathrm{O}_{2}\right)$ and redox-active quinones have revealed a dose-determined response in the mode of cell death. Low doses induce apoptosis, while higher doses trigger necrosis (Chandra et al., 2000). This phenomenon has been observed for both photodynamic agents and fatty acids. The plantderived phototoxin hypericin induces apoptosis at low doses and necrosis at high doses for the same time interval, when light fluence rate is held constant, in the acute promyelocytic leukemia cell line HL-60 (Lavie et al., 1999). The fatty acid arachidonic acid (AA) induces apoptosis at concentrations between 10-400 $\mu \mathrm{M}$ and necrosis at concentrations above $400 \mu \mathrm{M}$ in the human leukemia cell lines HL-60, Raji, and Jurkat as assessed by electron microscopy and flow cytometry (Pompeia et al., 2002).

In order to determine if PHT cytotoxicity is selective in the presence and/or absence of UVA irradiation and if the mode of cell death induced is dependent on PHT $\times$ UVA dose combinations, a preliminary study was performed using two different assays and an acute lymphoblastic leukemia (ALL) cell model. A leukemia cell model was chosen for comparative purposes. Cytoxicity of PAs isolated from Gymnaster koraiensis and Panax quinquefolium has been demonstrated in murine leukemia cell lines (L 1210) but not drug resistant human derived cell lines (Jung et al., 2002; Fujimoto et al. 1991).

The cell model used consisted of the CCRF-CEM pediatric acute lymphoblastic leukemia cell line and its multidrug-resistant variant CEM/VLB 100 . The CCRF-CEM cell line and its p-glycoprotein (pgp-170) over-expressing variant CEM/VLB 100 show 
different levels of expression of manganese superoxide dismutase (MnSOD), copper/zinc superoxide dismutase (Cu/ZnSOD) and catalase (CAT) (Jia et al. 1995). CCRF-CEM cell populations show higher levels of MnSOD activity and lower levels of $\mathrm{Cu} / \mathrm{ZnSOD}$ and $\mathrm{CAT}$ activity than $\mathrm{CEM} / \mathrm{VLB}_{100}$ cell populations. In addition, $\mathrm{CEM} / \mathrm{VLB}_{100}$ cells are more susceptible to TNF- $\alpha$ mediated cytotoxicity than the wild type cells but, show decreased uptake of vinca alkaloids and anthracyclines due to the overexpression of $p g p$ 170.

The MTT tetrazolium salt assay was used to measure metabolic activity 24 hours after treatment with a range of PHT concentrations $(0-200 \mu \mathrm{M})$ in combination with 4 different light levels $\left(0,0.414,1.4\right.$ and 2.5 joules $\left./ \mathrm{cm}^{2}\right)$. The loss in membrane integrity was monitored with a dual parameter flow cytometric assay using the fluorochromes annexin-V-FITC and propidium iodide (PI). In order to monitor the effects of a range of PHT doses $(0-80 \mu \mathrm{M})$ in combination with increasing levels of UVA light exposure on the loss of membrane integrity and cell viability over time, cells from treated populations were stained with annexin-V-FITC and PI at 3 hours and 23 hours after irradiation treatments were performed.

The MTT cytotoxicity assay is a microculture assay based on metabolic reduction of 3-(4, 5-dimethylthiazol-2-yl)-2, 5-diphenyltetrazolium bromide (MTT) (Mosman et al., 1983; Denizot et al., 1986). When then yellow tetrazolium salt is reduced by active mitochondrial dehydrogenases (oxidoreductases), purple formazan crystals are formed. The product can be quantitated colorimetrically using a microplate absorbance reader. There is a positive correlation between MTT absorbance readings and metabolic activity. A loss in phospholipid asymmetry is indicated by the translocation of the 
negatively charged aminophospholipid, phosphatidylserine (PS), to the outer leaf of the plasma membrane from the cytoplasmic side of the cell membrane. Annexin- $V$ was initially discovered as a vascular protein with strong anticoagulant properties and high binding affinity in a calcium $\left(\mathrm{Ca}^{2+}\right)$ dependent reaction with negatively charged aminophospholipid surfaces (Vermes et al., 1995). Propidium iodide (PI) is a membrane impermeable cationic dye that intercalates with DNA and can be used to monitor the loss of membrane integrity in late apoptotic and necrotic cells by flow cytometric means.

Membrane integrity is lost in necrotic and late apoptotic cells in vitro; the loss of plasma membrane integrity occurs early during cell necrosis but is a late event of apoptosis (Darzynkiewicz, 1997). Because PS is exposed in many apoptotic cell models and serves as one of the signals to phagocytes to digest them, this assay can be used in combination with morphological examinations to confirm the induction of apoptosis as the mode of cell death (Darzynkiewicz, 1997).

\section{MATERIALS AND METHODS}

\section{Chemicals.}

Camptothecin (Cat. \# C9911), propidium iodide (Cat. \# P4710), and annexin-VFITC (Cat. \# A9210) were all purchased from Sigma (St. Louis, MO). MTT (3-(4, 5dimethylthiazol-2-yl)-2, 5-diphenyltetrazolium bromide) kits were purchased from ATCC (Manassas, VA. cat. \#30-1010K) and Roche (Indianapolis, IN cat. \#1465007). AnnexinV-FLOUS was also purchased from Roche (Indianapolis, IN cat. \# 1828681). Cell culture materials were all purchased from Invitrogen (Carlsbad, CA). RPMI-1640 media (Cat. \#1 1875-093); phosphate buffered saline (PBS), (Cat\#14200-075); penicillin- 
streptomycin (Cat\#15140-148); L-glutamine (Cat. \# 25030-149); fetal bovine serum (FBS) (Cat\# 10082-147); trypan blue (Cat. \#15250-061).

Preparation of fresh leaves extract of $B$. alba var. radiata.

An ethanolic extract was prepared for bioassay by the methods outlined in Chapter 1 of this thesis.

Preparation of PHT sample.

PHT (1-phenylhepta-1, 3, 5-triyne) was isolated and purified from an ethanolic extract of $B$. alba var. radiata according to the procedures described in Chapter 1 of this thesis. Stock solutions were prepared in $95 \%$ ethanol to final concentrations ranging from $20-30 \mathrm{mM}$ and stored in amber vials at $-20^{\circ} \mathrm{C}$ to protect from heat and light. Molar concentration of PHT was determined using ultraviolet/visible spectrophotometry with the molar extinction coefficient $(\varepsilon)$ of $148,000 \mathrm{M}^{-1} \mathrm{CM}^{-1}\left(\varepsilon_{25 \mathrm{Inm}}\right)$. The molecular weight of PHT is 164 grams.

Cell lines and culture techniques.

The CCRF-CEM parental acute lymphoblastic leukemia cell line described by Foley et al. (1965) originated from ATCC strain \# CCL-119, and its pgp-170 overexpressing variant, $\mathrm{CEM} / \mathrm{VLB}_{100}$, cell line was drug selected for resistance to vinca alkaloids (Ramachandran et al., 2003). Both cell lines were a gift from Dr. Cheppail Ramachandran from the Miami Children's Hospital Research Institute, Miami, Florida. Using the flourochrome-conjugated monoclonal antibody MRK16 that reacts specifically 
with a surface epitope of human glycoprotein (pgp-170) the CCRF-CEM cell line was previously found to not express p-glycoprotein ( $p g p$-170), while the drug resistant variant, CEM/VLB 100 , overexpressed the protein (Ramachandran et al., 2003).

Resistance to the vinca alkaloid, vinblastine, and the anthracycline, doxorubicin, was maintained by challenging the cells every 8 weeks in medium containing either $0.1 \mu \mathrm{M}$ vinblastine or $300 \mathrm{ng} / \mathrm{ml}$ doxorubicin. The stability of resistance, as measured by drug uptake or accumulation of doxorubicin, was monitored every 4 weeks by flow cytometric measurements of drug uptake in the absence and presence of the pgp-170 inhibitor, verapamil.

CCRF-CEM and CEM/VLB ${ }_{100}$ cells were grown in suspension in RPMI 1640 medium supplemented with $12 \%$ fetal bovine serum (FBS), Penicillin (100 I.U./ $/$ l), Streptomycin $(100 \mu \mathrm{g} / \mathrm{ml})$ and $L$-glutamine $(2 \mathrm{mM})$. Cells were grown in an incubator set at $37^{\circ} \mathrm{C}$ in a humidified $5 \% \mathrm{CO}_{2}$ atmosphere. Cells were maintained at $0.2 \times 10^{6}$ $2.0 \times 10^{6}$ cells $/ \mathrm{ml}$, as determined by hemacytometer count, and fresh medium was added every 2-3 days.

Cells were harvested for bioassay work by centrifugation in the exponential growth phase $\left(0.8 \times 10^{6}-1.2 \times 10^{6}\right.$ cells $\left./ \mathrm{ml}\right)$. The cells were washed with phosphate buffered saline (PBS) and centrifuged at 250g (1115 rpm) for 5 minutes. Assays were performed only if cell viability was $95-99 \%$, determined by trypan blue exclusion. Cells were suspended in fresh medium to a density of $1.0 \times 10^{6}$ cells $/ \mathrm{ml}$ and seeded in 24 -well plates at a density of $0.5 \times 10^{6}$ cells $/ \mathrm{ml}$ to a final volume of $2 \mathrm{ml}$ in each well, by diluting 1:2 with medium containing drug or control treatments. 
Work was performed under attenuated light conditions by leaving the soft fluorescent lights off in the laminar flow hood and culturing during the nighttime hours or with all windows blinded.

\section{UVA irradiation treatments.}

Cell populations were exposed to controlled UVA light doses using a hand held Spectroline $\mathbb{B}$ lamp equipped with a Longlife ${ }^{\mathrm{TM}}$ filter. The integrated lamp output from $300 \mathrm{~nm}-400 \mathrm{~nm}$ was 0.0046 watts $/ \mathrm{cm}^{2} /$ second with peak output at $352 \mathrm{~nm}$. Figure 2.1 displays the emission spectra of the lamp. Cells were exposed to 3 different light levels by increasing time of exposure. The light treatments consisted of 1.5 minutes or 0.414 joules $/ \mathrm{cm}^{2}, 5$ minutes or $1.4 \mathrm{~cm}^{2}$ and 9 minutes or 2.38 joules $/ \mathrm{cm}^{2}$.

After pre-incubation with PHT for 1 hour, cells in 24 - well plates were removed from the incubator and placed in a dark laminar flow hood. The lids of the 24-well plates were removed and cells were exposed with the lamp set at a distance of $1 \mathrm{~cm}$ from the cell suspensions. The cells were then placed back in the incubator for another 3 to 23 hours.

Cytotoxicity assay.

Cytotoxicity of the organic partition of the $95 \%$ ethanolic extract of fresh $B$. alba var. radiata leaves and the purified polyacetylenic compound PHT (1-phenylhepta-1, 3, 5-triyne) in the CEM and CEM/VLB 100 cell lines was assessed using the 3-(4, 5dimethylthiazol-2-yl)-2, 5-diphenyltetrazolium bromide (MTT) cell proliferation assay.

Cells were treated with a range of drug concentrations from $0-50 \mu \mathrm{g} / \mathrm{ml}$ of the organic partition (solubilized in $95 \%$ ethanol) or $0-300 \mu \mathrm{M}(0-50 \mu \mathrm{g} / \mathrm{ml})$ of PHT (solubilized in 95\% ethanol). Negative controls included untreated cells (no drug or 
vehicle), cells treated with $0.1-1.0 \%$ vehicle ( $95 \%$ ethanol) and cells exposed to each UVA light irradiation level alone or in combination with $0.1-1.0 \%$ vehicle. A medium control was also included which consisted of medium, MTT, and buffer.

Cells were treated with drug, in triplicate, for 24 hours before transferring to 96 well plates with $6-12$ replicates per treatment. MTT was added at $5 \mu \mathrm{g} / \mathrm{ml}$ and cell cultures were incubated for an additional 8 hours to allow sufficient time for formazan crystal formation. Formazan crystals were solubilized overnight with buffer consisting of $0.1 \mathrm{~N} \mathrm{HCl}$ in anhydrous isopropanol and then absorbance readings were taken at $570 \mathrm{~nm}$ with a reference wavelength of $655 \mathrm{~nm}$, using a BioRad Microplate Reader. Each experiment was repeated independently 3-5 times.

Flow cytometric assay to monitor membrane integrity.

The membrane integrity of treated cells was monitored using annexin-Vfluorescein isothiocyanate (FITC) and propidium iodide (PI). Dual parameter analyses were performed on a Coulter Epics Elite ESP flow cytometer, using an argon laser emitting $15 \mathrm{~mW}$ at $488 \mathrm{~nm}$. A $525 \mathrm{~nm}$ band pass filter was used to detect fluorescein (green fluorescence) and a $575 \mathrm{~nm}$ band pass filter was used for PI detection (red fluorescence). Electronic compensation of the instrument was required due to overlapping of the two fluorochromes emission spectras. At least 10,000 events/cells were acquired, and cell populations were displayed as a dot-plot of log PI vs. log FITC. A quadrant marker was used to divide the two-parameter plot into four quadrants. Negative controls (untreated cells) and positive controls (cells treated with $4 \mu \mathrm{g} / \mathrm{ml}$ Camptothecin) were used to set the boundaries. 
Cells were treated with concentrations of PHT ranging from $0-100 \mu \mathrm{M}$. Cells were assigned to dark or UVA treatments as described under $U V A$ irradiation treatments. Negative controls included: untreated cells (no PHT and no ethanol); cells treated with $0.5-1 \%$ of the vehicle ( $95 \%$ ethanol); cells treated with $0.414,1.4$ or 2.38 joules $/ \mathrm{cm}^{2}$ UVA; both UVA and $0.5-1 \%$ vehicle.

Cell cultures were monitored after 4 and 24 hours of drug treatment, in order to establish a minimum incubation time and concentration, for loss of membrane integrity. At the end of the incubation periods, $5.0 \times 10^{5}$ cells were harvested by centrifugation from each treatment, washed in ice-cold $\mathrm{Ca}^{+}$and $\mathrm{Mg}^{+}$free phosphate buffered saline (PBS) and centrifuged for 5 minutes at $1400 \mathrm{rpm}(350 \mathrm{~g})$. The supernatant was decanted and cells were resuspended in $100 \mu \mathrm{l}$ annexin- $\mathrm{V}$ binding buffer or to a density of $5.0 \mathrm{x}$ $10^{6} / \mathrm{ml}$ in $5 \mathrm{ml}$ cell culture tubes. Cells were stained with $5 \mu \mathrm{l}$ annexin-V-FITC (50 $\mu \mathrm{g} / \mathrm{ml})$ and $10 \mu \mathrm{l}$ PI $(50 \mu \mathrm{g} / \mathrm{ml})$. After incubating in a dark laminar flow hood for 15-20 minutes, $400 \mu$ of annexin- $\mathrm{V}$ binding buffer was added to each sample and readings were taken within 1 hour. Each treatment was repeated independently 3-5 times.

\section{Statistical Analyses.}

MTT assay. The replicate absorbance readings for each treatment within an assay were averaged and then divided by the mean absorbance of the negative vehicle control and multiplied by 100 . Values were expressed as percent of control mean absorbance. These values were averaged across each independent replicate to obtain the mean percent \pm standard error (SE) of control mean absorbance for each treatment. Annexin-V-FITC/PI assay. 
Mean percent necrotic cells (annexin-V-FITC ${ }^{+} / \mathrm{PI}^{+}$), viable cells (annexin-VFITC $/ \mathrm{PI}^{*}$ ) or cells with disrupted membrane asymmetry (annexin-V-FITC ${ }^{+} / \mathrm{PI}$ ) were calculated as the mean percentage of 3-5 independent replicates. The data were expressed as the mean percentages of independent replicate samples where at least 10,000 events/cells were analyzed and represented as dot plots of log FITC versus log PI fluorescence.

Statistical analyses were performed by two-way and three-way analysis of variance (ANOVA) using SigmaStat for Windows, Version 3.00.0. Results were considered significant if $\mathrm{P}<0.05$. Subsequently, pairwise multiple comparison procedures were performed using the Holm-Sidak method. MTT assay experimental design.

The experimental design for the MTT assay consisted of 3 independent variables, (the cell line, PHT concentration and light intensity). There were 2 levels within cell line (CEM and CEM/VLB $\left.{ }_{100}\right), 6$ levels of concentration $(0,4,15,40,80,125 \mu \mathrm{M})$, and 4 light levels $\left(0,0.414,1.4,2.38\right.$ joules $\left./ \mathrm{cm}^{2}\right)$. The dependent variable was percent of vehicle control metabolic activity or percent of the MTT absorbance of the vehicle control expressed as $100 \%$. Untreated cells (not dosed with PHT, vehicle, nor irradiated with UVA) were cultured in parallel to monitor their viability and the effect of the vehicle ( $95 \%$ ethanol) on MTT reduction. Vehicle controls showed at least $89 \%$ and at most $110 \%$ of the metabolic activity of untreated controls. Annexin-V-FITC / PI assay experimental design.

The experimental design for the annexin-V-FITC/ PI assay consisted of 4 independent variables (the cell line, PHT concentration, light intensity and incubation 
time), and 3 dependent variables, (percentage of viable cells, percentage of cells with lost membrane asymmetry and percentage of cells without intact membranes). Initial statistical analyses involved separate three-way ANOVA tests with cell line, PHT concentration and light intensity as the independent variables for each incubation time and then PHT concentration, light intensity and incubation time as the independent variables for each cell line. These tests were performed separately for each dependent variable. The results reported only include those for which the data passed tests of normality and equal variances.

\section{RESULTS}

Cytoroxicity of $B$. alba ethanolic extract.

The ethanolic extract of $B$. alba var. radiata was initially screened by MTT for both dark and photomediated cytotoxicity in the parental CCRF-CEM cell line. A 50\% decrease in MTT reduction compared to the negative vehicle control was observed after 48 hour incubation with $50 \mu \mathrm{g} / \mathrm{ml}$ of the organic extracts in the dark treatment, or $5 \mu \mathrm{g} / \mathrm{ml}$ of the organic extract, in combination with 1.4 joules $/ \mathrm{cm}^{2}$ UVA irradiation, 1 hour into the incubation period (figure 2.2). A reduction in metabolic activity compared to the control $(95 \%$ ethanol at $0.5 \% \mathrm{v} / \mathrm{v})$ was observed with extract concentrations of at least 12 $\mu \mathrm{g} / \mathrm{ml}$ under attenuated light conditions $(\mathrm{P}<0.05)$, and $3 \mu \mathrm{g} / \mathrm{ml}$ in combination with 1.4 joules $/ \mathrm{cm}^{2}$ UVA irradiation $(\mathrm{P}<0.05)$.

Across all extract concentrations tested, there was a considerable decrease in MTT reduction in populations irradiated with 1.4 joules $/ \mathrm{cm}^{2}$ UVA 1 hour into the incubation period, compared to dark treatments $(P=0.014)$. 
Metabolic activity after 24 hour incubation with PHT.

To determine if PHT contributed to the cytotoxic effect of the ethanolic extract, it was isolated and tested for cytotoxic activity in the parental CCRF-CEM cell line and $\mathrm{MDR}, \mathrm{CEM} / \mathrm{VLB}_{100}$ cell line. Cells were treated for 24 hours with varying concentrations of drug, ranging from $0-200 \mu \mathrm{M}$, and assigned to 1 of 4 different UVA light intensity treatments $\left(0,0.414,1.4\right.$ and 2.5 joules $\left./ \mathrm{cm}^{2}\right)$, to which they were exposed 1 hour after incubation with PHT.

The cytotoxicity of PHT was concentration and light dependent $(\mathrm{P}<0.001)$ and the data revealed an interaction between light level and treatment concentration $(\mathrm{P}<$ 0.001). A concentration dependent effect was observed across all light levels and both cell lines from $0-150 \mu \mathrm{M}$ but within the dark treatment, only at concentrations greater than $80 \mu \mathrm{M}(\mathrm{P}<0.05)$ (figures 2.3 and 2.4).

\section{UVA Treatments.}

After incubation with PHT for 24 hours and exposure to UVA light, 1 hour into the incubation period, there was an observed concentration and light dependent effect on the mean percent of metabolically active cells, relative to the negative vehicle control in both cell lines $(\mathrm{P}<0.001)$. Within populations of both the CEM/VLB 100 and CCRFCEM cell lines, metabolic activity decreased relative to the dark treatment in populations exposed to at least 0.414 joules $/ \mathrm{cm}^{2} \mathrm{UVA}$ and PHT concentrations above $4 \mu \mathrm{M}$ or at least $15 \mu \mathrm{M}(\mathrm{P}<0.05)$. Within the UVA treatments, a concentration dependent effect was 
seen at 0.414 joules $/ \mathrm{cm}^{2}$ below PHT treatment concentrations of $15 \mu \mathrm{M}(\mathrm{P}<0.001)$ and at 1.4 and 2.5 joules $/ \mathrm{cm}^{2}(\mathrm{P}<0.001)$ below $4 \mu \mathrm{M}$.

In other words, the toxicity of $4 \mu \mathrm{M}$ PHT is more dependent on light exposure than concentration at while the toxicity of PHT concentrations above $15 \mu \mathrm{M}$ does not increased with UVA exposure. At PHT concentrations above $15 \mu \mathrm{M}$, the effect on cytotoxicity is not due to an increase in light level from 0.414 joules $/ \mathrm{cm}^{2}-2.5 \mathrm{joules} / \mathrm{cm}^{2}$ and at light levels of 1.4 joules $/ \mathrm{cm}^{2}$ and above. Therefore, a decrease in mean percent metabolically active cells cannot be attributed to an increase in PHT treatment concentrations in the range of $4-150 \mu \mathrm{M}$.

In conclusion, a PHT dose of at least $4 \mu \mathrm{M}$ is required to observe phototoxic effects on metabolic activity in response to photoexcitation with between 0.414 joules $/ \mathrm{cm}^{2}-2.38$ joules $/ \mathrm{cm}^{2}$ UVA. A light dose of 0.414 joules $/ \mathrm{cm}^{2}$ is at most what is needed for a phototoxic effect on cell viability comparable to UVA doses of 1.4 joules $/ \mathrm{cm}^{2}$ and above when the PHT treatment concentration is $15 \mu \mathrm{M}$ and above. Dark Treatments.

In cell cultures treated for 24 hours with PHT for 24 hours with PHT concentrations ranging from $0-150 \mu \mathrm{M}$, a greater loss in metabolic activity was observed in $\mathrm{CEM} / \mathrm{VLB}_{100}$ cell populations treated with PHT concentrations above $150 \mu \mathrm{M}$ than in CCRF-CEM cells (table 2.1).

A possible selective metabolic toxicity was further evaluated by monitoring MTT reduction 48 hours after treatment with an expanded range of treatment concentrations $(0$ $300 \mu \mathrm{M})$. The CEM/VLB ${ }_{100}$ cell line was more sensitive to PHT toxicity, under 
attenuated light conditions and across all concentrations, after a 48 hour incubation period $(\mathrm{P}=0.003)$. Please see chapter 3 of this thesis for the presentation and discussion of these results.

Effect of PHT on cell membrane integrity.

When measured by flow cytometry, cells defined as "viable" fell into the FITC /PI quadrant. Cells defined as "loss of membrane asymmetry" fell into the $\mathrm{FITC}^{+} / \mathrm{PI}^{-}$ quadrant because PS was exposed on the outer plasma membrane. Cells defined as "necrotic" fell into the $\mathrm{FITC}^{-} / \mathrm{PI}^{+}$or $\mathrm{FITC}^{+} / \mathrm{PI}^{+}$quadrant because both dyes were taken up as membrane integrity was lost.

Interaction effects on viability.

A considerable interaction between light level and concentration was observed in both cell lines $(\mathrm{P}<0.005)$. This interaction was represented by the following observations. A concentration-dependent effect on viability in populations dosed with 0.414 joules $/ \mathrm{cm}^{2}$ UVA in combination with $0-80 \mu \mathrm{M}$ PHT that intensified over time. A light-dependent effect that was most notable in populations dosed with less than $40 \mu \mathrm{M}$ PHT after 4 hours, and less than $80 \mu \mathrm{M}$ PHT after 24 hours.

Induction of phosphatidylserine exposure across time in treated cultures.

After 24 hours, a concentration dependent effect on loss of membrane asymmetry is seen across both cell lines $(P=0.009)$. However, this effect was only seen in cultures treated with $0-4 \mu \mathrm{M}$ PHT and after photoirradiation with 0.414 joules $/ \mathrm{cm}^{2}$ UVA. By 24 hours into the incubation period, cell populations treated with greater light $x$ 
concentration doses showed a considerable percentage with complete loss of membrane integrity.

Figures 2.6 and 2.7 show the log annexin-V-FITC versus log PI histograms obtained for CEM/VLB 100 and CCRF-CEM cell populations, respectively, after 24 hour treatment with PHT $(0-80 \mu \mathrm{M}) \pm$ UVA $\left(0.414-2.5\right.$ joules $\left./ \mathrm{cm}^{2}\right)$. A PHT concentration of $4 \mu \mathrm{M}$ in combination with 0.414 joules $/ \mathrm{cm}^{2}$ UVA was sufficient to induce a loss in membrane asymmetry after 24 hours $(P=0.004)$ in both cell lines. A concentrationdependent induction of PS exposure, in the absence of light excitation, was observed only in $\mathrm{CEM} / \mathrm{VLB}_{100}$ cell populations (table 2.2). Dense clusters are seen in the annexin-VFITC $^{+} / \mathrm{PI}^{-}$quadrants of histograms showing the populations treated with $40 \mu \mathrm{M}$ and 80 $\mu \mathrm{M}$ PHT (figure 2.6).

The 4 hour $\mathrm{CEM} / \mathrm{VLB}_{100}$ histograms and CCRF-CEM histograms show that a loss in membrane asymmetry was induced early in both cell lines (figures 2.4 and 2.5). Cell populations treated with 0.414 joules $/ \mathrm{cm}^{2}$ UVA and at least $15 \mu \mathrm{M}$ PHT showed a loss in membrane asymmetry as early as 4 hours post exposure $(P=0.006)$. There was a considerable light dependent induction of PS exposure in populations of both cell lines treated with $4 \mu \mathrm{M}$ PHT and irradiated with 0.414 joules $/ \mathrm{cm}^{2} \mathrm{UVA}(\mathrm{P}=0.009)$ (figures 2.4 and 2.5$)$.

Loss of membrane integrity or percentage of necrotic cells over time.

There was a time, PHT concentration, and light dependent effect on the mean percentage of necrotic cells observed in populations of both cell lines $(P<0.001)$. After as soon as 4 hours, a PHT concentration dependent effect on the mean percent necrotic 
cells was observed in both cell lines $(\mathrm{P}<0.001)$. At 4 hours post-exposure, necrotic cells were observed in populations of both cell lines exposed to at least $15 \mu \mathrm{M}$ PHT and at least 1.4 joules $/ \mathrm{cm}^{2}$ UVA $(\mathrm{P}<0.001)$.

At 4 hours, dense clusters of CEM/VLB 100 cells with complete loss of membrane integrity were observed by flow cytometry in populations treated with at least 0.414 joules $/ \mathrm{cm}^{2}$ UVA, in combination with at least $40 \mu \mathrm{M}$ PHT (figure 2.3). A comparable response was observed in the CCRF-CEM cell line after treatment with at least 1.4 joules $/ \mathrm{cm}^{2}$ UVA and at least $15 \mu \mathrm{M}$ PHT (figure 2.5).

After 24 hours, the mean percentage of necrotic cells increased in populations of both cell lines and the effect was concentration and light dependent at PHT concentrations of $4 \mu \mathrm{M}$ and above in combination with irradiation doses of 0.414 joules $/ \mathrm{cm}^{2}$ and above $(\mathrm{P}<0.001)$. Dense clusters of necrotic cells were observed after 24 hours in CEM/VLB 100 populations treated with at least $80 \mu \mathrm{M}$ PHT in the absence of light excitation and in those dosed with at least $4 \mu \mathrm{M}$ PHT and 0.414 joules $/ \mathrm{cm}^{2}$ UVA (figure 2.6). Dense clusters of cells with complete loss of membrane integrity could be observed in CCRF-CEM populations treated with at least $4 \mu \mathrm{M}$ PHT in combination with 1.4 joules $/ \mathrm{cm}^{2}$ UVA or at least $15 \mu \mathrm{M}$ PHT and 0.414 joules $/ \mathrm{cm}^{2}$ UVA (figure 2.7).

After 4 hours, the mean percentage of necrotic cells observed in both CCRF-CEM and CEM/VLB ${ }_{100}$ populations treated with 2.5 joules $/ \mathrm{cm}^{2}$ UVA compared to those treated with either 0.414 joules $/ \mathrm{cm}^{2}$ UVA or in the dark were considerably greater $(\mathrm{P}<0.05)$. In fact, almost $100 \%$ of the cells treated with at least $40 \mu \mathrm{M}$ PHT and 2.5 joules $/ \mathrm{cm}^{2}$ UVA could be defined as necrotic after 4 hours (figures 2.3 and 2.4). After 24 hours, from 80 - 
$100 \%$ of the cells in populations of both cell lines treated with at least 0.414 joules $/ \mathrm{cm}^{2}$ UVA in combination with $80 \mu \mathrm{M}$ PHT or at least 1.4 joules $\mathrm{cm}^{2}$ and at least $40 \mu \mathrm{M}$ PHT showed complete loss of membrane integrity (figure 2.3).

\section{DISCUSSION}

In this study the effects of PHT on metabolic activity and membrane integrity were evaluated, in a MDR ALL cell model, in the presence and absence of UVA irradiation. PHT demonstrated selective toxicity in the dark to the MDR cell line and this cell line was also slightly more sensitive when dosed with PHT and photo-irradiated. In addition, a notable interaction between concentration and UVA light intensity was observed. A minimum PHT concentration required for photo-excitation was established in these cell lines as well as a minimum level of UVA light intensity for phototoxicity. At the minimum PHT concentration required for photoactivation, light dependent cytotoxicity was evident and at the minimum irradiation level required for photoexcitation, concentration-dependent toxicity was evident. Phototoxin induced membrane integrity loss was observed very early in the incubation period at the highest PHT $\times$ UVA combinations, indicative of primary necrosis. However, cell populations treated with lower dose combinations lost plasma membrane asymmetry before integrity, suggesting secondary necrosis or late apoptosis.

The results of the MTT assay and annexin-V-FITC/PI flow cytometric assay correlated well. The selective toxicity of PHT in the dark to CEM/VLB ${ }_{100}$ cells was demonstrated in both assays. The data indicate that after 24 hours, a loss in membrane 
asymmetry is accompanied by disfunction of cellular metabolism, as measured by the ability of mitochondrial dehydrogenases to reduce the tetrazolium salt, MTT.

PAs show potent anti-proliferative activity, independent of their phototoxicity, but their mechanisms of action and structure activity relationships are poorly understood. Studies with fatty acids and derivatives have shown the degree of unsaturation or the number of double bonds (alkenes) positively correlates with cytotoxicity and formation of lipid peroxides in many cell types. Examples include pancreatic cancer cells and HL60 acute promyelocytic leukemia cells (Hawkins et al., 1998). In addition, analogs of ceramide, which is synthesized from long chain fatty acids, possessing double bonds (alkene) and triple bonds (alkyne) show greater relative potency to induce apoptosis, as assessed by nuclear chromatin condensation and DNA fragmentation, in HL-60 cells than analogues lacking these structural characteristics (Kishida et al., 1997). The presence of an aromatic group on the fatty acid butyrate confers anti-proliferative activity (Shack et al., 1996). The aromatic fatty acid phenylbutyrate has been evaluated in phase I and II clinical trials, in combination with other anti-cancer agents, for the treatment of nonresponsive hematologic, small intestine, and advanced colorectal cancers (Gore, 2001; Carducci, 2000; Sung, 2002). Comparative studies with PAs of varying structure are needed to further understand the effects of aromatic groups and conjugation and number of acetylenic bonds on the bioactivity attributed to these compounds under attenuated light conditions.

While $\mathrm{CEM} / \mathrm{VLB}_{100}$ populations show greater sensitivity to PHT toxicity, a loss in viability was observed in both cell lines under attenuated light conditions at concentrations greater than $200 \mu \mathrm{M}$. At the greatest PHT concentrations and PHT $\times$ 
UVA combinations tested, cytotoxicity may be due to nonspecific membrane disruption rather than induction of a specific apoptotic signaling pathway. By contrast, at the lowest PHT concentrations required for loss of metabolic activity and membrane asymmetry in CEM/VLB 100 populations, a specific cell death pathway may be induced by PHT. This cell death pathway may involve the production of reactive oxygen species such as superoxide anion and lipid peroxidation end products.

Previous work with PHT demonstrated phototoxicity in insect models to be inhibited by increased activity of endogenous superoxide dismutase (SOD) and when supplemented with the lipid soluble antioxidants, $\alpha$-tocopherol and $\beta$-carotene (Aucoin $e t$ al., 1995). Insects also show effects of lipid peroxidation if glutathione (GSH) is inhibited before administering PHT and irradiating with UVA. The greater sensitivity of $\mathrm{CEM} / \mathrm{VLB}_{100}$ cell populations relative to CCRF-CEM cell populations to $\mathrm{PHT}$, both under attenuated and controlled UVA light conditions, may thus involve differences between the two cell lines in levels of expression of endogenous antioxidant defenses.

This suggests that the toxicity of PHT is associated with the production of superoxide anions and lipid hydroperoxides (LOOHs) and the depletion or down regulation of antioxidant enzyme expression. PHT reacts with molecular oxygen upon photoexcitation with UVA light to produce oxyradicals such as superoxide anion. Alternatively, singlet oxygen is produced upon photoexcitation of PHT with UVA light that reacts with PUFAs in cell membranes to form LOOHs. Human breast cancer cells (MCF-7) overexpressing phospholipid hydroperoxide glutathione peroxidase (Ph-GPx) are able to rapidly remove phototoxin produced $\mathrm{LOOHs}$ and preserve membrane integrity (Wang et al., 2001). Superoxide is produced by mitochondria during the mitochondrial 
route of apoptosis induction but overexpression of MnSOD causes reduced levels of intracellular reactive oxygen species and prevents cell death. MnSOD removes superoxide radicals in mitochondria and thus protects mitochondria from oxidative injury (Cai et al., 1998). Polyunsaturated fatty acid derivatives mediate toxicity through an increase in the generation of ROS and rate of lipid peroxide formation and depletion of endogenous antioxidant defenses (Das, 2002). Phenylacetate and phenylbutyrate induced time dependent decreases in GSH levels, SOD activity, catalase (CAT), glutathione peroxidase (GPx), glutathione reductase (GR), and glutathione-S-transferase (GST) (Shack et al., 1996). MDR ovarian and colon carcinoma cell populations were also more sensitive to growth arrest by phenylacetate and phenylbutyrate than those of the parental cell line. Treatment with these compounds chemosensitized the MDR cells to doxorubicin toxicity.

Jia et al. (1995) showed the CEM/VLB 100 cell line to be more sensitive to TNF- $\alpha$ induced apoptosis than the parental CCRF-CEM cell line. This selective toxicity was associated with decreased MnSOD activity. The apoptosis-inducing activity of TNF- $\alpha$ is mediated by the production of reactive oxygen intermediates (ROI) and inhibited by the over-expression of SOD (Siemankowski et al., 1999, Gaur et al., 2003). The $\mathrm{CEM} \mathrm{VLB}_{100}$ cells are also more sensitive than CCRF-CEM cells to cytosine $\beta$-Darabinofuranoside induced apoptosis (Allen et al., 1995). This anti-cancer drug targets the mitochondria and stimulates the production of ROS (Cai et al., 1998).

PHT may modulate the expression of antioxidant enzymes and may depending on the dose used and whether it is tested in combination with UVA irradiation or other prooxidant drugs. Subtoxic doses of prooxidants may stimulate the upregulation of 
enzymatic antioxidant defense and intracellular SOD may be involved in the resistance of cancer cells to oxidative stress (Sen et al., 2003; Matés et al., 2000). Ionizing radiation, anthracyclines, and cytokines such as TNF- $\alpha$, produce free radicals that aid in their anticancer activity (Das, 2002). TNF- $\alpha$ induces apoptosis in the MCF-7 human breast adenocarcinoma-derived cell line but increases MnSOD expression by northern blot hybridization analyses (Siemankowski et al., 1999). A correlation was found between elevated serum levels of MnSOD and recurrence of disease in human epithelial ovarian carcinoma patients and decreased levels after chemotherapy with combinations of cyclophosphamide, doxorubicin and cisplatin (Ishikawa et al., 1990). Patients with highgrade central nervous system (CNS) tumors show increased levels of MnSOD in their cerebrospinal fluid (Cobbs et al., 1996). Malignant gliomas with high constitutive expression of MnSOD are resistant to endogenous TNF- $\alpha$ mediated toxicity, ionizing radiation induced cytotoxicity and DNA damage, and chemotherapeutic agents that may induce TNF- $\alpha$. Ionizing radiation also causes increases in MnSOD expression that can confer resistance to TNF- $\alpha$ mediated cytotoxicity (Lin et al., 1993). Lymphocyte samples from pediatric ALL patients recently diagnosed and prior to treated with anticancer drugs, showed lower levels of the antioxidant enzymes, GPx, CAT, and SOD than those from control groups (Sentüker et al., 1997). These reports illustrate the contribution of endogenous antioxidants to drug resistance.

The increased sensitivity of $\mathrm{CEM} / \mathrm{VLB}_{100}$ cells to $\mathrm{PHT}$ toxicity may also involve differences in the expression of apoptosis regulating genes. In addition to the protection provided by antioxidant defense mechanisms, cell death induced by pro-oxidants can be prevented by cancer associated, or oncogenes, that regulate apoptosis. The $b c l-2$ gene 
family members encode for the expression proteins that act as either pro-apoptotic (bax and $b c l$-xs) or anti-apoptotic (bcl-2 and $b c l$-xL) (Klasa et $a l ., 2001)$. The TNF- $\alpha$ sensitive CEM/VLB ${ }_{100}$ cell line showed increased expression of the pro-apoptotic $b c l-x s, b a d$, and bax genes in the mitochondria than cells from CCRF-CEM populations (Jia et al., 1999). Treatment with TNF- $\alpha$ increased $b c l-2$ gene expression in mitochondria of CCRF-CEM cells but decreased levels in CEM/VLB 100 cells. Mitochondrial apoptosis can be inhibited by overexpression of $b c l-2$ and $b c l-x \mathrm{~L}$. The expressed of $b c l-2$ protein is believed to inhibit the induction of apoptosis by functioning as an antioxidant to attenuate drug induced hydrogen peroxide and lipid peroxide formation or to induce the production of endogenous antioxidants (Cai et al., 1998). Fatty acids and derivatives have shown the ability to modulate the expression of these genes. The butyric acid derivative, AN-9, induces apoptosis in cultured B-chronic lymphocytic leukemia (B-CLL) cells from patients alone and in combination with doxorubicin (Rabizadeh et al., 2001). This compound also downregulated $b c l-2$ and upregulated $b a x$ gene expression alone and in a supra-additive manner when cells were coincubated with doxorubicin. The PUFA, eicosapentaenoic acid (EPA) was shown to induce apoptosis of HL-60 cells and downregulate $b c l-2$ expression (Chiu et al., 1999).

In this study, PHT was shown to induce the externalization of the negatively charged aminophospholipid, phosphatidylserine (PS) from the inner plasma membrane to the outer plasma membrane. Under attenuated light conditions, the effect was selective to the $\mathrm{CEM} / \mathrm{VLB}_{100}$ cell line. After photoexcitation, PS externalization was observed in populations of both cell lines treated with all but the highest PHT $\times$ UVA combinations. 
PS, when externalized to the outer membrane indicates a loss in plasma membrane asymmetry. PS exposure is common in many cell systems as a response to a variety of apoptotic stimuli (Verhoven et al., 1999). In apoptotic lymphocytes (DO11.10 T lymphocyte hybridoma cells), DNA fragmentation and membrane blebbing may occur after PS externalization. Furthermore, PS exposure is required for phagocytosis by macrophages (Verhoven et al., 1999). An asymmetric distribution of phospholipids is maintained in lymphocytes by an ATP-dependent translocase called aminophospholipid translocase (APT). The externalization of PS to the outer leaflet of the plasma membrane requires the inactivation of APT and the activation of an enzyme called scramblase (Verhoven et al. 1999). APT activity has been shown to be sensitive to oxidation and it has been proposed that oxidized PS fails to be internalized by APT (Kagan et al., 2000). Kagan et al. (2003) demonstrated that oxidation of PS occurs early during the execution of apoptosis and prior to DNA fragmentation and PS externalization. In addition, PS peroxidation is blocked in cells overexpressing $b c l-2$ and is sensitive to broad-spectrum caspase inhibitors. The family of aspartic acid specific cysteine proteases (caspases) is implicated in the initiation and execution of apoptosis. The naturally derived phototoxin hypericin, (from Hypericum perforatum L., Clusiaceae), induced externalization of PS which in turn was prevented by specific caspase- 3 inhibitors and broad-spectrum caspase inhibitors (Ali et al., 2001). However, data are not conclusive as to whether APT and scramblase are direct targets of caspases (Verhoven et al., 1999). The molecular mechanisms that lead to the externalization of PS remain unresolved (Kagan et al., 2000). Apoptosis was induced in leukemic cells from newly diagnosed pediatric ALL patients by the drugs, prednisolone, vincristine, $L$-asparaginase, and the anthracycline, 
daunorubicin (Holleman et al., 2003). Apoptosis induction was characterized by early PS exposure and mitochondrial membrane depolarization followed by caspase-3 activation (Holleman et al., 2003). The investigators found that the leukemic cells of patients that were resistant to these structurally unrelated drugs showed decreased PS externalization and mitochondrial transmembrane depolarization compared to drug sensitive cells.

The increased sensitivity of CEM/VLB 100 to PHT- induced loss in membrane asymmetry may be related to the increased activity of the mitochondrial electron transport chain (ETC) activity of this cell line compared to the CCRF-CEM cell line (Jia et al., 1997). The increased sensitivity of CEM/VLB 100 cells to TNF- $\alpha$ was demonstrated to involve its higher ETC activity. By contrast, the resistance of this cell line to high dose vinblastine-induced apoptosis was increased when the ETC was depleted with ethidium bromide. The susceptibility of CEM/VLB 100 cells to TNF- $\alpha$ was also related to a depolarized mitochondrial state that primes cells for apoptotic induction. Mitochondrial depolarization occurs as an early event in apoptosis of $C E M / V^{2} B_{100}$ cells exposed to TNF- $\alpha$ and but not in CEM cells (Matarrese et al., 2001).

High dose PHT $\times$ UVA combinations seemed to cause cell lysis shortly after photoirradiation, without an apparent initial loss of membrane asymmetry. Cell death may have occurred in these populations via necrosis or through major homeostatic failure rather than by apoptosis. Extreme oxidative stress can disrupt mitochondrial energy production and lead to a rapid depletion of ATP that would shunt cells to a necrotic death because the apoptotic program is an energy dependent process (Raffray et al., 1997). Sufficient ATP reserves are required for caspase activation, PS externalization and formation of apoptotic bodies. 
One of the means by which cancer cells mediate drug resistance is through upregulating the expression of detoxifying enzymes and anti-apoptotic proteins. Drugs that can modulate the expression of these enzymes may be valuable in cancer treatment protocols (Kong et al., 1998).

Further work should involve elucidating the mechanism of toxicity of PHT in cancer cell lines with defined levels of detoxifying enzyme expression and in the presence of exogenous antioxidants. The ability of PHT to modulate the expression of these enzymes along with that of anti and pro-apoptotic proteins should be investigated. In addition, morphological examination of cells for the hallmarks of apoptosis such as cell shrinkage, membrane blebbing, chromatin condensation and nuclear fragmentation should be performed. The possible route of apoptosis induced by PHT, whether extrinsic (death-receptor associated) or intrinsic (mitochondrial route) also needs to be elucidated. In this study, selective toxicity of PHT was demonstrated in a MDR, ALL cell line that overexpresses $p g p-170$. The potential for PHT to work additively or supraadditively with the anti-cancer drug doxorubicin was investigated and the results are reported in Chapter 3 of this thesis. 
Figure 2.2. Emission spectra of lamp used for UVA irradiation treatments. The figure shows the spectra from $300-500 \mathrm{~nm}$ with a lambda maximum at $352 \mathrm{~nm}$. The integrated output from $300-400 \mathrm{~nm}$ was 0.0046 watts $/ \mathrm{cm}^{2} / \mathrm{second}$.

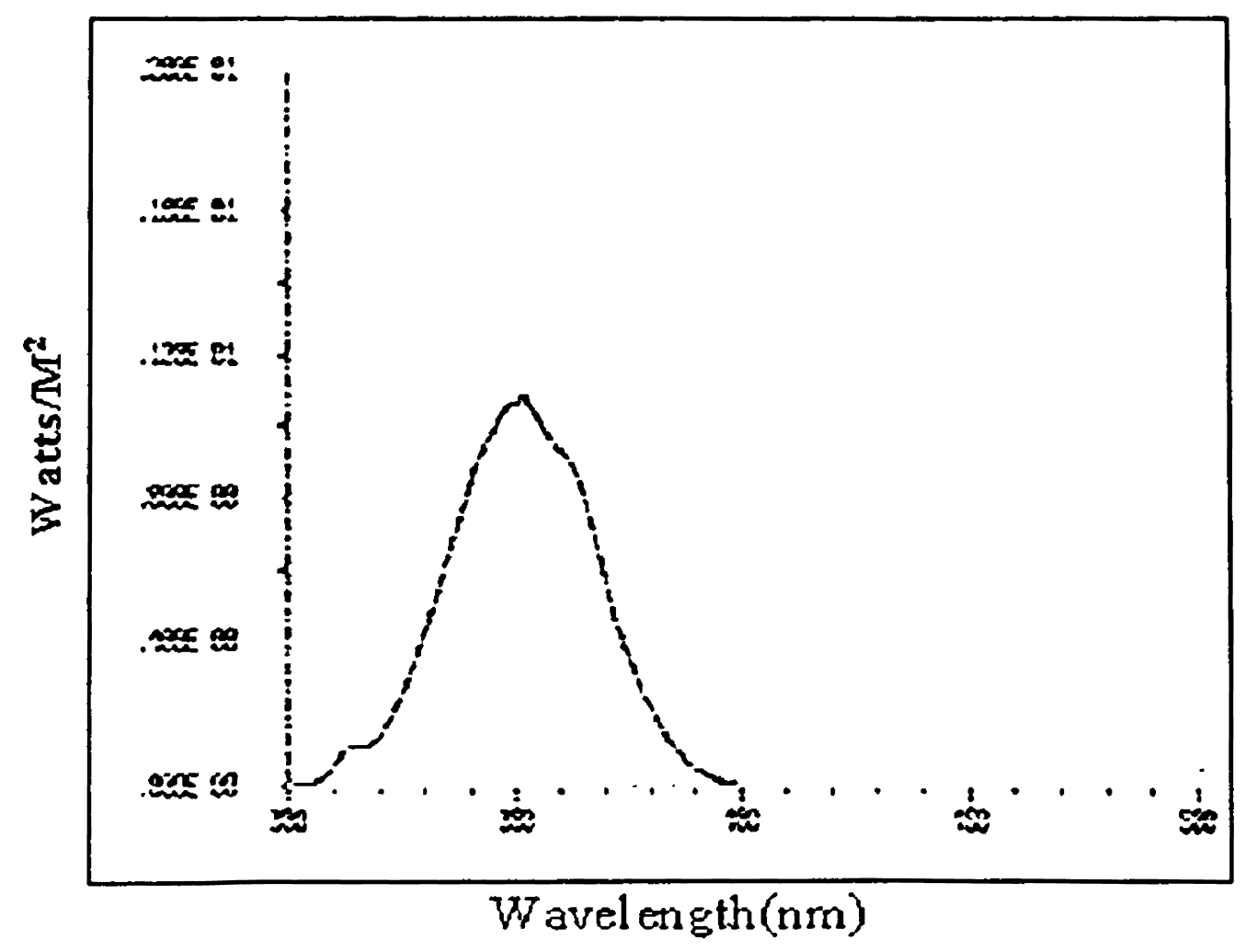




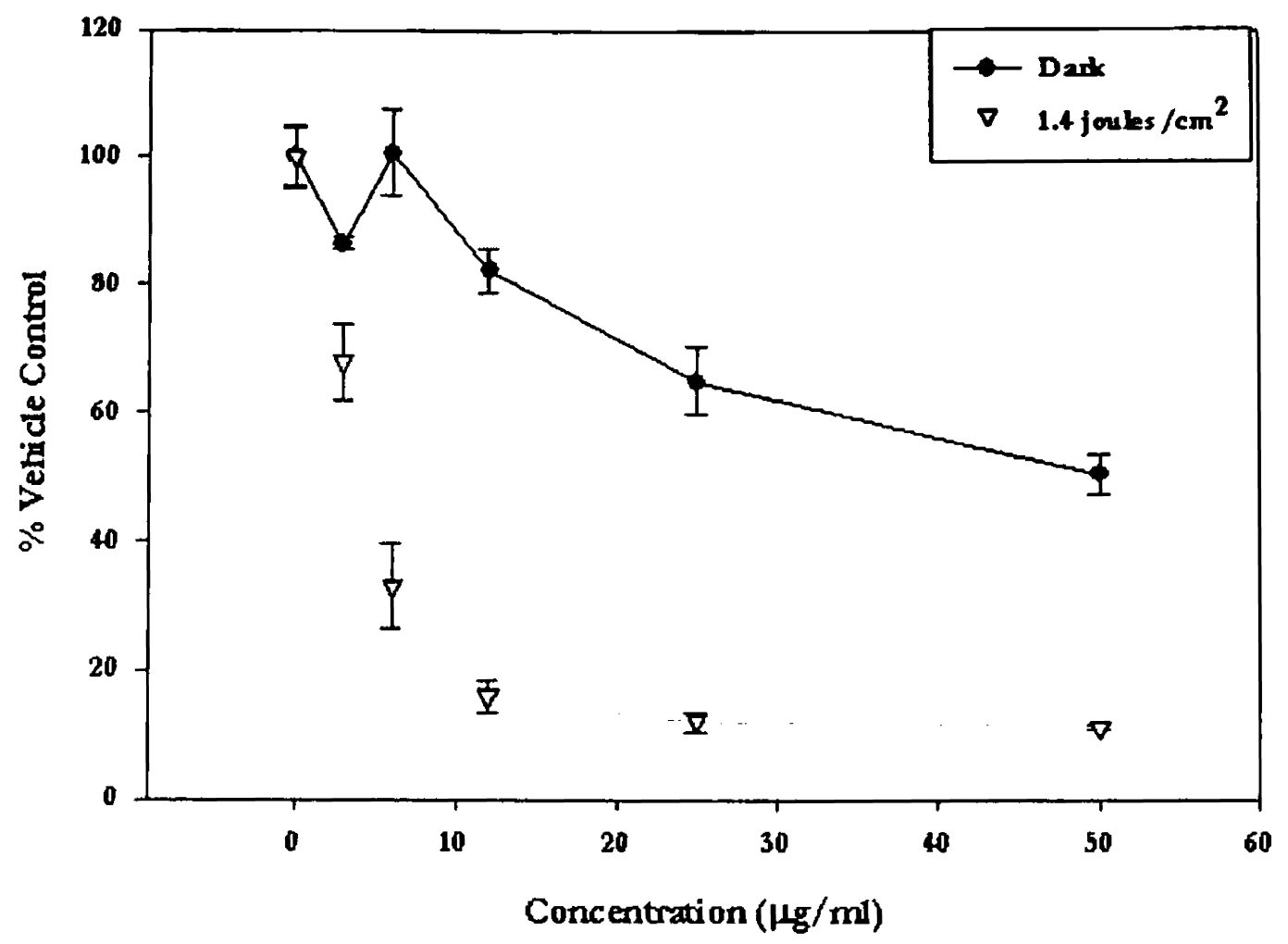

Figure 2.3. Metabolic activity of CCRF-CEM cells after incubation with $B$. alba ethanolic extract. Cells were treated under attenuated light conditions or with 1.4 joules $/ \mathrm{cm}^{2}$ UVA, 1 hour into the incubation period. The vehicle control was $0.5 \%$ ethanol. Data points represent the mean of 4-6 replicates within an independent replicate assay averaged across 3-5 independent assays. Errors bars represent the mean $\pm \mathrm{SE}$. 
$\mathbf{A}$
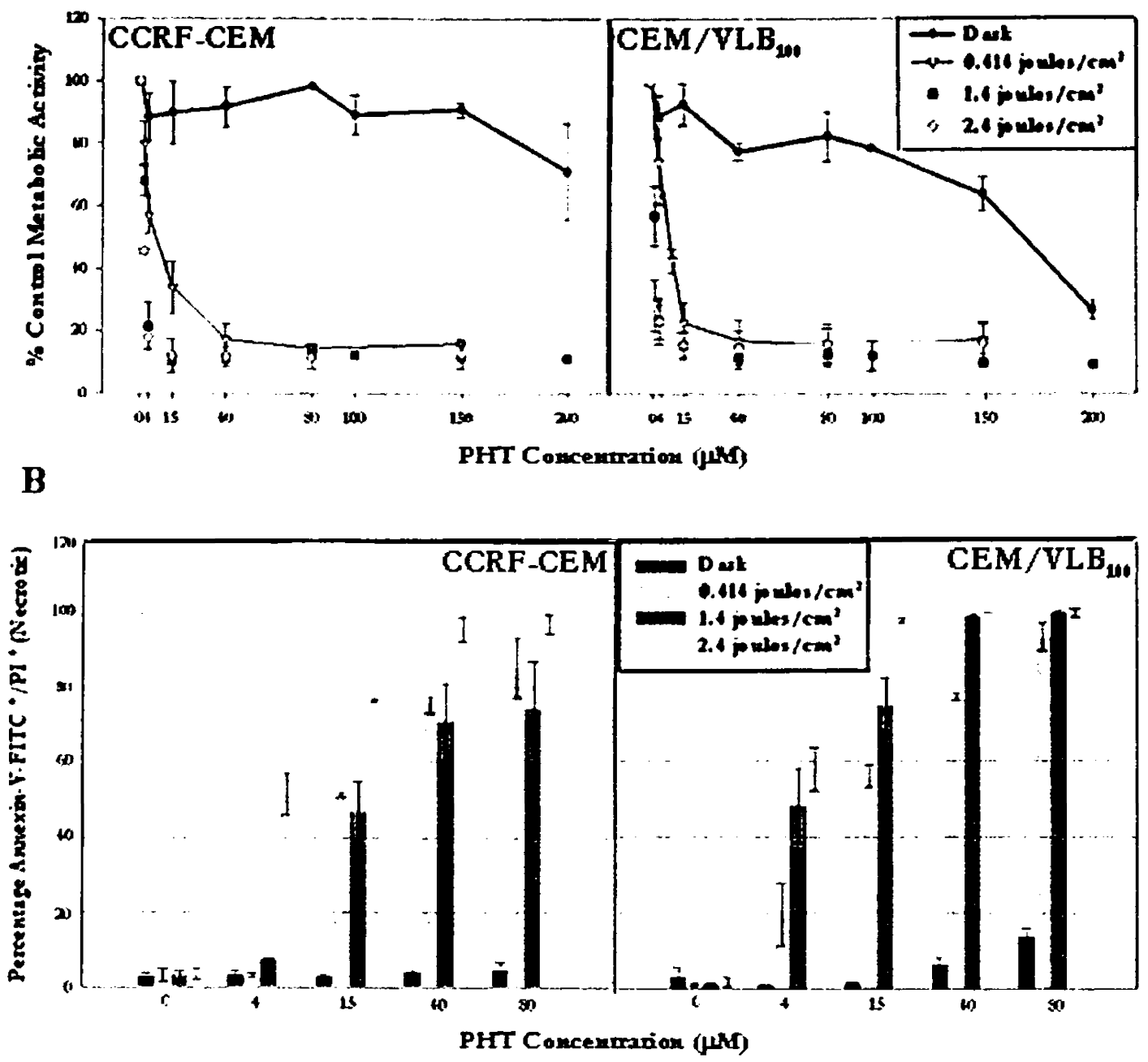

Figure 2.4. Metabolic activity and membrane integrity of CCRF-CEM and CEM/VLB 100 cells after 24 hour incubation with PHT \pm UVA. Graph A shows the MTT assay results as percent vehicle control versus varying PHT concentration. Each data point represents the mean $\pm \mathrm{SE}$ of 3-5 independent replicate treatments performed in quadruplicate. Graph B shows the percentage of cells with complete loss of membrane integrity (annexin-V-FITC ${ }^{+} / \mathrm{PI}^{+}$) versus PHT concentration. Each bar represents the mean $\pm \mathrm{SE}$ of 3-5 independent replicate treatments. 
Table 2.1. Metabolic activity of CCRF-CEM and CEM/VLB ${ }_{100}$ cells after 24 hour incubation with PHT \pm UVA irradiation.'

CCRF-CEM

\begin{tabular}{|c|c|c|c|c|}
\hline \multicolumn{5}{|c|}{ UVA } \\
\hline Concentration $(\mu M)$ & Dark & 0.414 joul $\mathrm{es} / \mathrm{cm}^{2}$ & 1.4 joules $/ \mathrm{cm}^{2}$ & 2.4 joul $\mathrm{es} / \mathrm{cm}^{3}$ \\
\hline $\begin{array}{l}0 \\
4\end{array}$ & $\begin{array}{c}100 \\
883 \pm 76\end{array}$ & $\begin{array}{c}100 \\
56.9 \pm 5.9\end{array}$ & $\begin{array}{c}100 \\
21.4 \pm 76\end{array}$ & $\begin{array}{c}100 \\
18.0 \pm 3.4\end{array}$ \\
\hline 15 & $89.7 \pm 10$ & $33.8 \pm 8.3$ & $10.9 \pm 1.8$ & $122 \pm 52$ \\
\hline 40 & $917 \pm 63$ & $17.3 \pm 5.1$ & $11.4 \pm 17$ & $118 \pm 3.2$ \\
\hline 80 & $908 \pm 22$ & $14.6 \pm 1.2$ & $13.4 \pm 2.4$ & $117 \pm 40$ \\
\hline 100 & $89.1 \pm 6.4$ & & & \\
\hline 150 & $90.8 \pm 2.2$ & & & \\
\hline \multicolumn{5}{|c|}{ CEMNILB $1 M$} \\
\hline \multicolumn{5}{|c|}{ UVA } \\
\hline Concentration $(\mu \mathrm{M})$ & Dark & 0.414 joul $\mathrm{es} / \mathrm{cm}^{2}$ & 1.4 joules $/ \mathrm{cm}^{2}$ & 2.4 joul $\mathrm{es} / \mathrm{cm}^{2}$ \\
\hline 0 & 100 & 100 & 100 & $\begin{array}{c}100 \\
220+53\end{array}$ \\
\hline 4 & $88.8 \pm 6.9$ & $42.7 \pm 3.9$ & $23.2 \pm 7.3$ & $22.9 \pm 5.3$ \\
\hline 15 & $928 \pm 79$ & $22.6 \pm 6.5$ & $15.4 \pm 4.4$ & $156 \pm 38$ \\
\hline 40 & $776 \pm 57$ & $16.9 \pm 6.5$ & $11.6 \pm 3.9$ & $146 \pm 5.4$ \\
\hline 80 & $824 \pm 29$ & $15.4 \pm 5.4$ & $12.8 \pm 43$ & $158 \pm 63$ \\
\hline 100 & $780 \pm 108$ & & & \\
\hline 150 & $63.9 \pm 12.1$ & & & \\
\hline 200 & $26.8 \pm 8.1$ & & & \\
\hline
\end{tabular}

I. Values represent percent (\%) vehicle control (ethanol) $\pm \mathrm{SE}$ of the mean. 
Table 2.2. Percentage of cells with loss in membrane asymmetry after 24 hour incubation with PHT \pm UVA exposure.'

CCRF-CEM

\begin{tabular}{|c|c|c|c|c|}
\hline \multicolumn{5}{|c|}{ UVA } \\
\hline Concentration ( $\mu M)$ & Dark & 0.414 joul $\mathrm{es} / \mathrm{cm}^{2}$ & 1.4 joules $/ \mathrm{cm}^{2}$ & 2.4 joul es/ $\mathrm{cm}^{2}$ \\
\hline 0 & $6.2 \pm 2.0$ & $7.1 \pm 2.8$ & $6.8 \pm 4.1$ & $9.7 \pm 3.4$ \\
\hline 4 & $6.6 \pm 1.4$ & $160 \pm 3.5$ & $316 \pm 3.0$ & $26.2 \pm 4.4$ \\
\hline 15 & $10.6 \pm 2.2$ & $20.1 \pm 0.4$ & $26.0 \pm 5.6$ & $18.3 \pm 1.1$ \\
\hline 40 & $9.1 \pm 1.1$ & $27.1 \pm 8.2$ & $15.4 \pm 9.0$ & $3.5 \pm 2.9$ \\
\hline 80 & $12.8 \pm 3.1$ & $9.8 \pm 4.1$ & $9.7 \pm 5.7$ & $1.8 \pm 1.7$ \\
\hline \multicolumn{5}{|c|}{ CEMNLB,O } \\
\hline \multicolumn{5}{|c|}{ UVA } \\
\hline Concentration $(\mu M)$ & Dark & 0.414 joul $\mathrm{es} / \mathrm{cm}^{2}$ & 14 joules $/ \mathrm{cm}^{2}$ & 2.4 joul $\mathrm{es} / \mathrm{cm}^{2}$ \\
\hline 0 & $58 \pm 3.5$ & $57 \pm 4.9$ & $6.4 \pm 4.6$ & $7.3 \pm 4.7$ \\
\hline 4 & $4.9 \pm 1.2$ & $42.3 \pm 2.4$ & $40.5 \pm 6.3$ & $35.5 \pm 9.2$ \\
\hline 15 & $8.7 \pm 3.4$ & $37.8 \pm 1.7$ & $23.6 \pm 7.4$ & $2.2 \pm 0.4$ \\
\hline 40 & $23.3 \pm 5.5$ & $17.9 \pm 0.4$ & $1.8 \pm 0.4$ & $0.7 \pm 0.1$ \\
\hline 80 & $42.5 \pm 6.5$ & $6.0 \pm 2.8$ & $0.9 \pm 0.6$ & $0.4 \pm 0.2$ \\
\hline
\end{tabular}

1. Values represent the mean percentage of 10,000 cells that were annexin-V-FITC ${ }^{+} / \mathrm{PI}^{-} \pm \mathrm{SE}$ of $3-5$ independent replicates. 


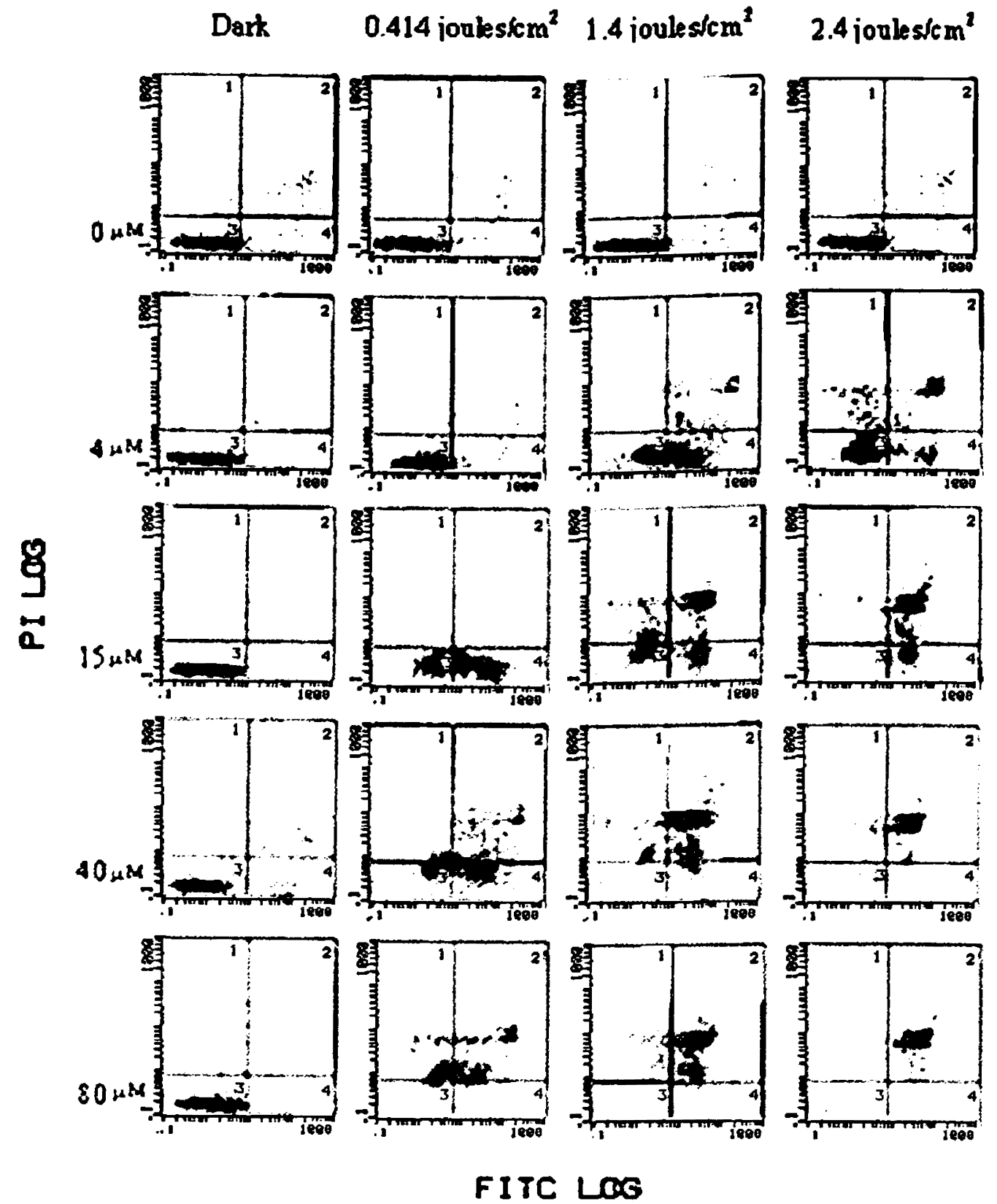

Figure 2.5. Membrane integrity of $\mathrm{CEM} / \mathrm{VLB} \mathrm{B}_{100}$ cells after 4 hour incubation with PHT \pm UVA irradiation. At least 10,000 cells were collected and displayed as dot plots of PI log vs. FITC log. The 4 quadrants of each histogram are: 1. annexin-V-FITC $/ \mathrm{PI}^{+}$2. annexin-V-FITC ${ }^{+} / \mathrm{PI}^{+}$. 3. annexin-V-FITC $/ \mathrm{PI}^{-}, 4$. annexin-V-FITC ${ }^{+} / \mathrm{PI}^{-}$. The histograms shown are representative of the $3-5$ independent replicates performed for each treatment. 


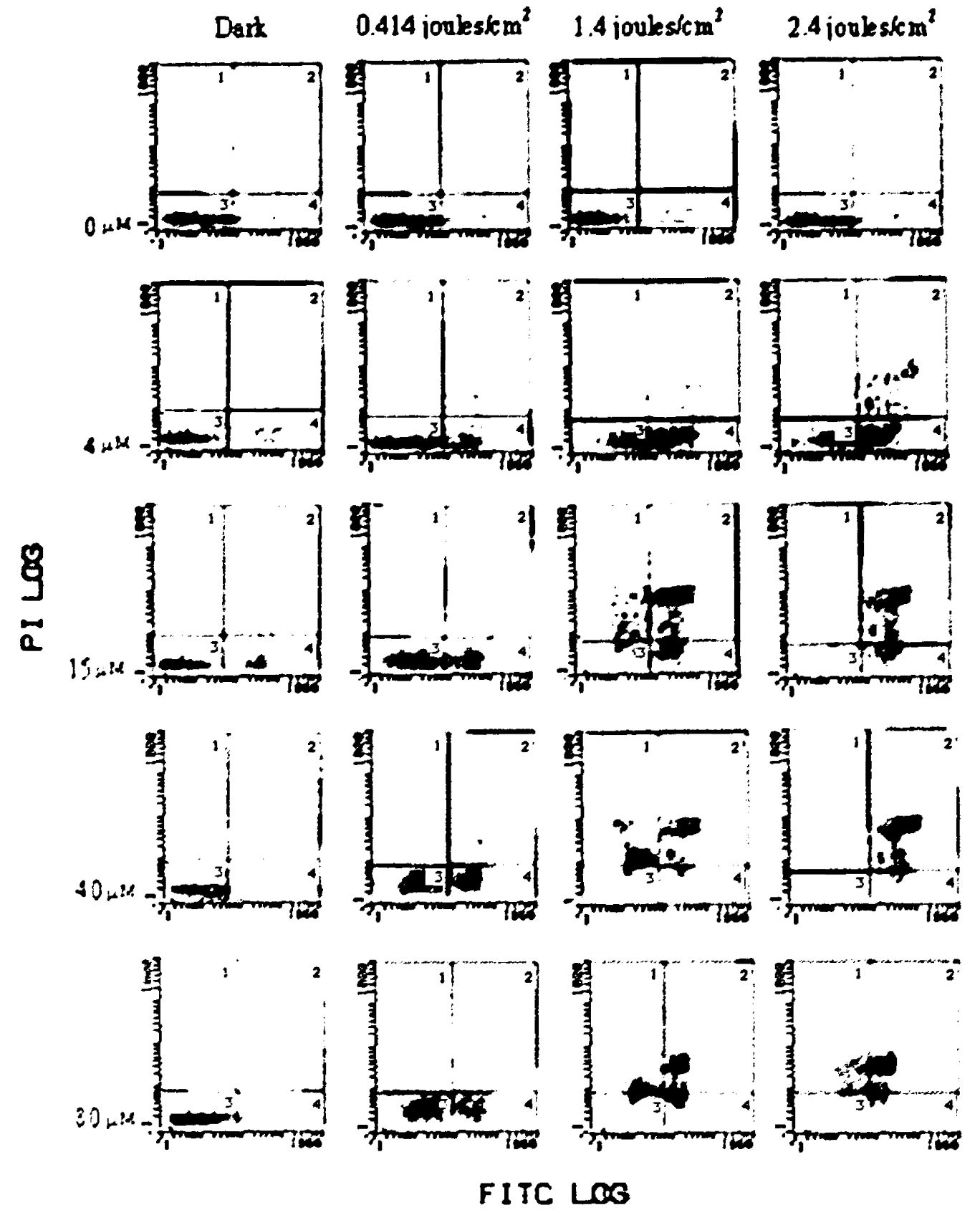

Figure 2.6. Membrane integrity of CEM cells after 4 hour incubation with PHT \pm UVA irradiation. At least 10,000 cells were collected and displayed as dot plots of PI log vs. FITC log. The 4 quadrants of each histogram are: 1 . annexin-V-FITC $/ \mathrm{PI}^{+} ; 2$. annexin-V$\mathrm{FITC}^{+} / \mathrm{PI}^{+}$; 3. annexin-V-FITC $/ \mathrm{PI}^{-} ; 4$. annexin-V-FITC ${ }^{+} / \mathrm{PI}^{-}$. The histograms shown are representative of the 3-5 independent replicates performed for each treatment. 


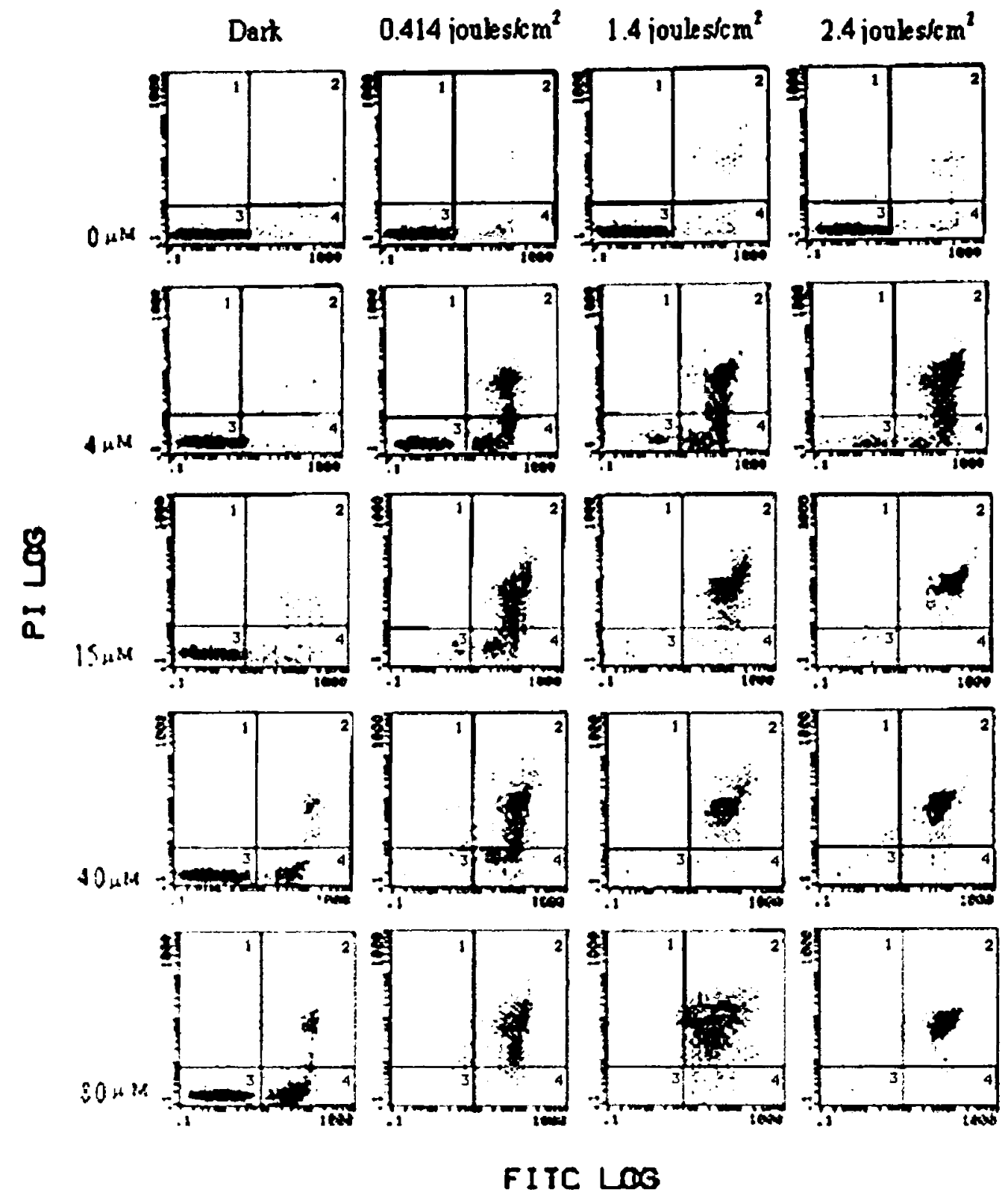

Figure 2.7. Membrane integrity of CEM/VLB ${ }_{100}$ cells after 24 hour incubation with PHT in combination with UVA irradiation. At least 10,000 events were collected and displayed as dot plots of PI log vs. FITC log. The 4 quadrants of each histogram are: 1 . annexin-V-FITC $/ \mathrm{PI}^{+} ; 2$. annexin-V-FITC ${ }^{+} / \mathrm{PI}^{+} ; 3$. annexin$\mathrm{V}-\mathrm{FITC}^{-} / \mathrm{PI}^{-} ; 4$. annexin-V-FITC ${ }^{+} / \mathrm{PI}^{-}$. The histograms shown are representative of the 3-5 independent replicates performed for each treatment. 

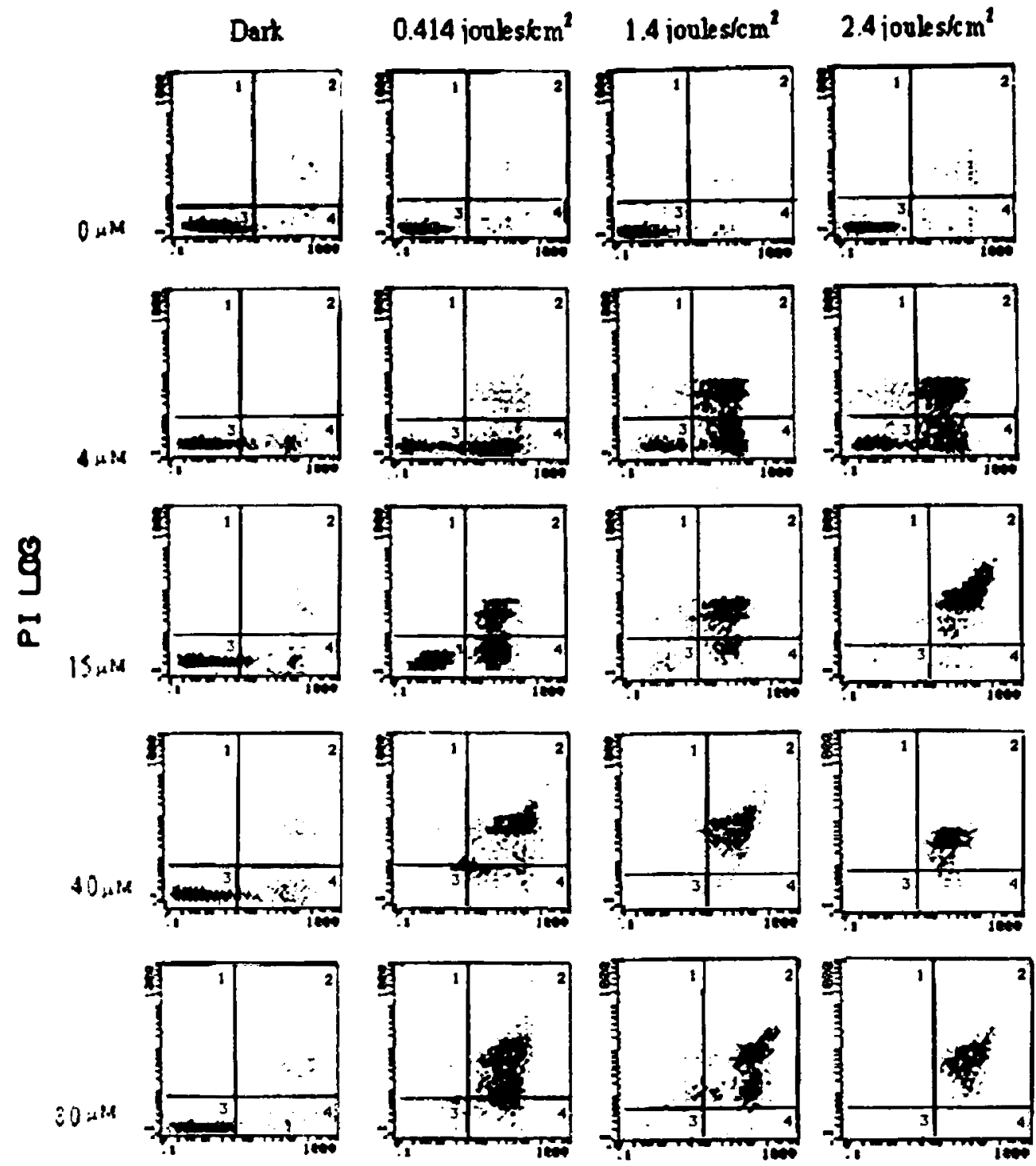

FITC LOS

Figure 2.8. Membrane integrity of CEM cells after 24 hour incubation with PHT in combination with UVA irradiation. At least 10,000 events were collected and displayed as dot plots of PI log vs. FITC log. The 4 quadrants of each histogram are: 1 . annexin-VFITC $/ \mathrm{PI}^{+} ; 2$. annexin-V-FITC $/ \mathrm{PI}^{+} ; 3$. annexin-V-FITC $/ \mathrm{PI}^{-} ; 4$. annexin-V-FITC ${ }^{+} / \mathrm{PI}^{-}$. The histograms shown are representative of the 3-5 independent replicates performed for each treatment. 


\section{LITERATURE CITED}

Alam N, Bae BH, Hong J, Lee CO, Im KS, Jung JH.2001.Cytotoxic diacetylenes from the stony coral Montipora species. J Nat Prod. 64:1059-1063.

Allen PD, Jiang XR, Ketly NJ, Razak K, Gutteridge CN, Kelsey SM, Newland AC.1995. Drug induced apoptosis in multi-drug resistant derivatives of the K562 and CEM cell lines. Brit J Haematol 89:37.

Ali SM, Olivo M, Yuen GY, Chee SK.2001.Induction of apoptosis by Hypericin through activation of caspsase-3 in human carcinoma cells. Int J Mol Med 8:521-530.

Anderson D.1996.Antioxidant defences against reactive oxygen species causing genetic and other damage. Mutat Res 350: 103-108.

Anel A, Naval J, Desportes P, González B, J, Piñeiro A.1992.Increased cytotoxicity of polyunsaturated fatty acids on human tumoral $b$ and t-cell lines compared with normal lymphocytes. Leukemia 6:680-688.

Arita K, Yamamoto Y, Takehara Y, Utsumi T, Kanno T, Miyaguchi-Akiyama J, Yoshioka T, Utsumi K.2003.Mechanisms of enhanced apoptosis in HL-60 cells by UV-irradiated n-3 and n-6 polyunsaturated fatty acids. Free Radical Bio Med 35:189-199.

Arnason T, Wat CK, Downum K., Yamamoto E., Graham E., Towers GH.1980.

Photosensitization of Escheria coli and Saccharomyces cerevisiae by phenylheptatriyne from Bidens pilosa. Can J Microbiol 26:698-705.

Aucoin R, Guillet G, Murray C, Philogene JR, Arnason JT.1995. How do insect herbivores cope with the extreme oxidative stress of phototoxic host plants? Arch Insect Biochem. 29:211-226.

Bernart MW, Cardellina JH, II Balaschak MS, Alexander MR, Shoemaker RH, Boyd MR.1996.Cytotoxic Falcarinol Oxylipins from Dendropanax arboreus. J Nat Prod 59:748-753.

Bohlmann FT. Burkhardt T, Zdero C.1973.Naturally Occurring Acetylenes. Academic Press, London.

Brown GC, Borutaite V.2002.Nitric oxide inhibition of mitochondrial respiration and its role in cell death. Free Radical Bio Med 33:1440-1450.

Buttke TM, Sandstrom PA.1994.Oxidative stress as a mediator of apoptosis. Immunol Today 15:7-10. 
Cai J, Jones DP.1998.Superoxide in apoptosis: mitochondrial generation triggered by cytochrome $c$ loss. J Biol Chem 273:1 1401-11404.

Carducci MA.2000.Phase I Study of Azacitidine and Phenylbutyrate in Patients With Refractory Advanced Solid Tumors. On Line: Line: http://cancer.gov/clinicaltrials/JHOC-99120302.

Castegna A., Lauderback CM, Mohmmad-Abdul H, Butterfield DA.2004.Modulation of phospholipid asymmetry in synaptosomal membranes by the lipid peroxidation products, 4-hydroxynonenal and acrolein: implications for Alzheimer's disease Brain Res 100:193-197.

Chandra J, Samali A, Orrenius S.2000.Triggering and modulation of apoptosis by oxidative stress. Free Radical Bio Med 29:323-333.

Chau YP, Shiah SG, Don MJ, Kuo ML.1998.Involvement of hydrogen peroxide in topoisomerase inhibitor $\beta$-lapachone-induced apoptosis and differentiation in human leukemia cells. Free Radical Bio Med 24:660-670.

Chin HW, Lin CC, Tang KS.1995.Anti-inflammatory activity of Taiwan folk medicine "ham-hong-chho" in rats. Am J Chinese Med 23:273-8.

Chiu LC, Wan JM.1999.Induction of apoptosis in HL-60 cells by eicosapentaenoic acid (EPA) is associated with downregulation of bcl-2 expression. Cancer Lett 45:1727.

Choi YE, Ahn H, Ryu JH .2000.Polyacetylenes from Angelica gigas and their inhibitory activity on nitric oxide synthesis in activated macrophages. Biol Pharm Bull 23:884-886

Cobbs C, Levi DS, Aldape K, Israel MA.1996.Manganese superoxide expression in human central nervous system cancers. Cancer Res 56:3192-3195.

Cos P, Hermans N., Van Poel B., De Bruyne T, Apers S, Sindambiwe JB, Vanden Berghe D, Pieters L, Vlietinck AJ.2002.Complement modulating activity of Rwandan medicinal plants. Phytomedicine 9:56-61.

Curtin JF, Donovan M, Cotter TG.2002.Regulation and measurement of oxidative stress in apoptosis. J Immunol Methods 265:49-72.

Dai JR, Hallock YF, Cardellina II JH, Gray GN, Boyd MR.1996.Triangulynes A-H and triangulynic acid, new cytotoxic polyacetylenes from the marine sponge Pellina triangulata. J Nat Prod 59:860-865. 
Darzynkiewicz Z, Juan G, Wojciech G, Murakami T, Traganos F.1997.Cytometry in cell necrobiology: analysis of apoptosis and accidental cell death (necrosis).

Cytometry 27:1-20.

Das UN.1999.Essential fatty acids, lipid peroxidation and apoptosis. Prostag Leukotr Ess 61:157-163.

Das UN.2002.A radical approach to cancer. Med Sci Monit 8:RA79-92.

Debatin KM, Poncet D, Kroemer G.2002.Chemotherapy: targeting the mitochondrial cell death pathway. Oncogene 21: 8786-8803.

Debatin KM, Stahnke K, Fulda S.2003.Apoptosis in hematological disorders. Semin Cancer Biol 13:149-158.

Denizot F., Lang R.1986.Rapid colorimetric assay for cell growth and survival. J Immunol Methods 89:271.

Downum KR.1992.Tansley review no.43 light-activated plant defence. New Phytol 122:401-420.

Ebermann R, Alth G., Kreitner M, Kubin A.1996.Natural products derived from plants as potential drugs for the photodynamic destruction of tumor cells. J Photoch Photobio B 36:95-97.

Foley GE, Lazarus H, Farber S, Uzman BG, Boone BA, McCarthy RE.1965.Continuous culture of human lymphoblasts from peripheral blood of a child with acute leukemia. Cancer 18:522-529.

Fujimoto Y, Satoh M, Takeuchi N, Kirisawa M.1991. Cytotoxic acetylenes from Panax quinquefolium. Chem Pharm Bull (Tokyo). 39:521-523.

Fullas F., Brown DM, Wani MC, Wall ME, Chagwedera TE, Farnsworth NR, Pezzuto JM, Kinghorn AD.1995.Gummiferol, a cytotoxic polyacetylene from the leaves of Adenia gummifera. J Nat Prod 58:1625-1628.

Gaur U, Aggarwal BB.2003. Regulation of proliferation, survival and apoptosis by members of the TNF superfamily. Biochem Pharmacol 66:1403-1408.

Geissberger P, Sequin U.1991.Constituents of Bidens pilosa L.: Do the components found so far explain the use of this plant in traditional medicine? Acta Trop 48:251-261.

Gopalakrishna R, Jaken S, Gopalakrishna R, Jaken S.2000.Protein kinase C signaling and oxidative stress. Free Radical Bio Med 28:1349-1361. 
Gore SD.2001.Phase I Study of Phenylbutyrate and Tretinoin in Patients With Myelodysplastic Syndromes, Chronic Myelomonocytic Leukemia, or Acute Myeloid Leukemia. On Line: http://cancer.gov/clinicaltrials/JHOC-J9879.

Hawkins RA, Sangster K, Arends MJ.1998.Apoptotic death of pancreatic cancer cells induced by polyunsaturated fatty acids varies with double bond number and involves an oxidative mechanism. J Pathol 185:61-70.

Hedley DW, McCulloch EA, Minden MD, Chow S, Curtis J.1998. Antileukemic action of buthionine sulfoximine: evidence for an intrinsic death mechanism based on oxidative stress. Leukemia 12:1545-1552.

Hoelzer D, Gokbuget N.2000.New approaches to acute lymphoblastic leukemia in adults: where do we go? Semin Oncol 27:540-59.

Holleman A, den Boer ML, Kazemier KM, Janka-Schaub GE, Pieters R.2003.Resistance to different classes of drugs is associated with impaired apoptosis in childhood acute lymphoblastic leukemia. Neoplasia 102:4541-4546.

Hudson JB, Graham EA, Towers GHN.1982. Nature of the interaction between the photoactive compound phenylheptatriyne and animal viruses. Photochem Photobiol 36:181-185.

Hudson JB, Graham EA, Towers GHN.1986.Investigation of the antiviral action of the photoactive compound phenylheptatriyne. Photochem Photobiol 43:27-33.

Hughes-Fulford M, Chen Y, Tjandrawinata RR.2001.Fatty acid regulates gene expression and growth of human prostate cancer PC-3 cells. Carcinogenesis 22:701-707.

Ishikawa M, Yaginuma Y, Hayashi H, Shimizu T, Endo Y, Taniguchi N.1990.Role of monoclonal antibody to manganese superoxide disputes with human ovarian carcinoma. Cancer Res 50:2538-2542.

Ito A, Cui B, Chavez D, Chai HB, Shin YG, Kiwanis K, Cardoon LBS.2001.Cytotoxic oxyacetylene from the twigs of Ochanostachys amentacea. J Nat Prod 64: 246248.

Jager AK, Hutchings A, van Staden J.1996.Screening of Zulu medicinal plants for prostaglandin-synthesis inhibitors. J Ethnopharmacol 52:95-100.

Jia L. Allen PD, Macey MG, Grahn MF, Newland AC, Kelsey SM.1997.Mitochondrial electron transport chain activity, but not ATP synthesis, is required for drug induced apoptosis in human leukemic cells: a possible novel mechanism of regulating drug resistance. Brit J Haematol 98: 686-698. 
Jia L., Jiang XR, Razak K, Wu YL, Newland AC, Kelsey SM.1995.TNF- mediated killing of human leukemic cells: effects of endogenous antioxidant levels and TNF- $\alpha$ expression in leukemic cell lines. Leukemia Res 19:187-194.

Jia L., Macey G, Yin Y, Newland AC, Kelsey SM.1999.Subcellular distribution and redistribution of $b c l-2$ family proteins in human leukemia cells undergoing apoptosis. Neoplasia 93:2353-2359.

Jung HJ, Min BS, Park JY, Kim YH, Lee HK, Bae KH.2002.Gymnasterkoreaynes A-F, cytotoxic polyacetylenes from Gymnaster koraiensis. J Nat Prod 65:897-901.

Kagan VE, Fabisiak JP, Shvedova AA, Tyurina YY, Tyurin VA, Schor NF, Kawai K.2000. Oxidative signaling pathway for externalization of plasma membrane phosphatidylserine during apoptosis. FEBS 477:1-7.

Kagan VE, Borisenko GG, Serinkan BF, Tyurina YY, Tyurin VA, Jiang J, Liu SX, Shvedova AA, Fabisiak JP, Uthaisang W, Fadeel B.2003.Appetizing rancidity of apoptotic cells for macrophages: oxidation, externalization, and recognition of phosphatidylserine. Am J Physiol Lung Cell Mol Physiol. 285:L1-L17.

Kaufmann SH.1998. Cell death by topoisomerase-targeted drugs: more questions than answers. Biochim Biophys Acta 1400:195-211.

Kayo A, Kobuchi H, Utsumi T, Takehara Y, Akiyama J, Horton AA, Utsumi K.2001.Mechanism of apoptosis in HL-60 cells induced by n-3 and n-6 fatty acids. Biochem Pharmacol 62:821-828.

Kishida E, Kasahara M, Takagi Y, Matsumura M, Hayashi T, Kobayashi S, Masuzawa Y.1997.Evaluation of a trans configuration for the apoptosis-inducing activity $f$ ceramide. J Lipid Mediat Cell 16:127-137.

Klasa RJ, List AF, Cheson BD.2001.Rational approaches to design of therapeutics targeting molecular markers. Hematology (Am Soc Hematol Educ Program) 443462.

Kong Q, Lillehei KO.1998.Antioxidant inhibitors for cancer therapy. Med Hypotheses 51: k405-409.

La E, Kern JC, Atarod EB, Kehrer JP.2003. Fatty acid release and oxidation are factors in lipoxygenase inhibitor-induced apoptosis. Toxicol Lett 138: 193-203.

Lavie G, Kaplinsky C, Toren A, Aizman I, Meruelo D, Mazur Y, Mandel M.1999.A photodynamic pathway to apoptosis and necrosis induced by dimethyl tetrahydroxyhelianthrone and hypericin in leukemic cells: possible relevance to photodynamic therapy. Brit J Cancer 79:423-432. 
Liesveld JL, Abboud CN, Lu C, McNair II C, Menon A, Smith A, Rosell K, Lin CC, Kan WS.1990.Medicinal plants used for the treatment of hepatitis in Taiwan. Am J Chinese Med 18:35-43.

Lin PS, Ho KC, Sung SJ, Tsai S.1993.Cytotoxicity and manganese superoxide dismutase induction by tumor necrosis factor- $\alpha$ and ionizing radiation in MCF-7 human breast carcinoma cells. Lymphokine Cytok Res 12:303-308.

Lowe SW, Lin AW.2000.Apoptosis in cancer. Carcinogenesis 21:485-495.

Matarrese P, Testa U, Cauda R, Vella S, Gambardella L, Malomi.2001.Expression of P170 glycoprotein sensitizes lymphoblastoid CEM cells to mitochondria-mediated apoptosis. Biochem J 355:587-595.

Matés JM, Sánchez-Jiménez FM.2000.Role of reactive oxygen species in apoptosis: implications for cancer therapy. Int J Biochem Cell B 32:157-170.

Matsunaga H, Katano M, Yamamoto H, Fujito H, Mori M, Takata K.1990.Cytotoxic activity of polyacetylene compounds in Panax ginseng C. A. Meyer. Chem Pharm Bull 38:3480-3482.

McLachlan D, Arnason T., Lam J.1986.Structure-function relationships in the phototoxicity of acetylenes from the Asteraceae. Biochem Syst Ecol 14:17-23.

McRae DG, Yamamoto E, Towers GHN.1985. The mode of action of polyacetylene and thiophene photosensitizers on liposome permeability to glucose. Biochim Biophys Acta 821:488-496.

Mirzoeva OK, Sudina GF, Pushkareva MA, Varfolomeev SD.1995.Competitive inhibition of the 5-lipoxygenase-catalysed linoleate oxidation by arachidonic acid and 5-hydroperoxy-eicosatetraenoic acids. FEBS Lett 377:306-308.

Mosmann T.1983. Rapid colorimetric assay for cellular growth and survival: application to proliferation and cytotoxicity assays. J Immunol Methods 65:55-63.

Nakano Y, Matsunaga H, Saita T, Mori M, Katano M, Okabe H. 1998.Antiproliferative constituents in Umbelliferae plants II. Screening for polyacetylenes in some Umbelliferae plants, and isolation of panaxynol and falcarindiol from the root of Heracleum moelledorffii. Biol Pharm Bull. 21:257-61.

Narayanan BA, Narayanan NK, Desai D, Pittman B, Reddy BS.2004.Effects of a combination of docosahexaenoic acid and 1,4-phenylenebis (methylene) selenocyanate on cyclooxygenase-2, inducible nitric oxide synthase and $\{$ beta $\}$ catenin pathways in colon cancer cells. Carcinogenesis Aug. 5 (Epub ahead of print). 
Öllinger K, Kågedal K.2002.Induction of apoptosis by redox-cycling quinones. Quin PJ, Kagan VE eds. In: Subcellular Biochemistry, volume 36: Phospholipid metabolism in apoptosis. Academic/Plenum Publishers, New York.

Pompeia C, Freitas JJS, Kim, JS, Zyngier SB, Curi R.2002.Arachidonic acid cytotoxicity in leukocytes: implications of oxidative stress and eicosanoid synthesis. Biol Cell 94:251-265.

Park BY, Min BS, Oh SR, Kim JH, Kim TJ, Kim DH, Bae KH, Lee HK.2004.Isolation and anticomplement activity of compounds from Dendropanax morbifera. J Ethnopharmacol 90:403-408.

Pereira RLC, Ibrahim T, Lucchetti L, da Silva AJR, Goncalves de Moraes VL.1999.Immunosuppressive and anti-inflammatory effects of methanolic extract and the polyacetylene isolated from Bidens pilosa L. Immunopharmacology 43:31-37.

Preuss M, Girnun GD, Darby CJ, Khoo N, Spector AA, Robbins MEC.2000.Role of antioxidant enzyme expression in the selective cytotoxic response of glioma cells to $\gamma$-linolenic acid supplementation. Free Radical Bio Med 28:1 143-1156.

Rabizadeh E, Bairey O, Aviram A, Ben-Dror I, Shaklai M, Zimra Y.2001.Doxorubicin and a butyric acid derivative effectively reduce levels of $\mathrm{BCL}-2$ protein in the cells of chronic lymphocytic leukemia patient. Eur J Haematol 66:263-71.

Raffray M, Cohen GM.1997.Apoptosis and necrosis in toxicology: a continuum or distinct modes of cell death. Pharmacol Ther 75: 153-177.

Ramachandran C, Thangaiyan R, Fonseca HB, Melnick SJ, Escalon EA.2003.Novel plant triterpenoid drug Amooranin overcomes multidrug resistance in human leukemia and colon carcinoma cell lines. Int J Cancer 105:784-789.

Ravindranath Y.2003.Recent advances in pediatric acute lymphoblastic and myeloid leukemia. Curr Opin Oncol 15:23-35.

Redl K, Breu W, Davis B. Bauer R.1994.Anti-inflammatory active polyacetylenes from Bidens campylotheca. Planta Med 60:58-62.

Robinson, H.1981.A revision of the tribal and subtribal limits of the Heliantheae (Asteraceae). Smithsonian Contributions to Botany 51:1-102.

Rose DP, Connolly JM.1999.Omega-3 fatty acids as cancer chemopreventive agents. Pharmacol Therapeut 83:217-244. 
Saha D, Pyo H, Choy H.2003.Cox-2 inhibitor as a radiation enhancer: new strategies for the treatment of lung cancer. Am J Clin Oncol 26:S70-74.

Sánchez-Alcázar JA, Bradbury DA, Pang L, Knox AJ.2003.Cyclooxygenase (COX) inhibitors induce apoptosis in non-small cell lung cancer through cyclooxygenase independent pathways. Lung Cancer 40:33-44.

Sarg TM, Ateya AM, Farrag NM, Abbas FA.1991.Constituents and biological activity of Bidens pilosa L. grown in Egypt. Acta Pharm Hung 61:317-323.

Sen P, Mukherjee S, Bhaumik G, Das P, Ganguly S, Choudhury N, Raha S.2003. Enhancement of catalase activity by repetitive low-grade $\mathrm{H}_{2} \mathrm{O}_{2}$ exposures protects fibroblasts from subsequent stress-induced apoptosis. Mutat Res 529:8794.

Sentüker S, Karahalil M, Inal H, Yilmaz H, Müslümanoglü H, Gedikoglu G, Dizdaroglu M.1997.Oxidative DNA base damage and antioxidant enzyme levels in childhood acute lymphoblastic leukemia. FEBS Lett. 416:286-290.

Shack S, Miller A, Liu L, Prasanna P, Thibault A, Samid D.1996. Vulnerability of multidrug-resistant tumor cells to the aromatic fatty acids phenylacetate and phenylbutyrate. Clin Cancer Res 2:865-872.

Siemankowski LM, Morreale J, Briel MM.1999.Antioxidant defenses in TNF-treated MCF-7 cells: selective increase in MnSOD. Free Radical Biol Med 26:919-924.

Stoll BA.2002.N-3 fatty acids and lipid peroxidation in breast cancer inhibition. Brit J Nutr 87:193-198.

Sung MW.2002.Phase I/II Study of Fluorouracil, Phenylbutyrate, Indomethacin, and Interferon Gamma in Patients With Advanced Colorectal Adenocarcinoma. On Line: http://cancer.gov/clinicaltrials/MTS-96322-ME.

Swannie H.C., Kaye S.B.2002.Protein kinase C inhibitors. Curr Oncol Rep 4:37-46.

Towers GHN, Hudson JB. 1987. Potentially useful antimicrobial and antiviral phototoxins from plants. Photochem Photobiol 46:61-66.

Tyurina YY, Tyurin VA, Liu SX, Smith CA, Shvedova AA, Schor NF, Kagan VE.2002. Phosphatidylserine peroxidation during apoptosis. A signaling pathway for phagocyte clearance. Subcell Biochem 36:79-96.

Verhoven B, Krahling S, Schlegel RA, Williamson P.1999.Regulation of phosphatidylserine exposure and phagocytosis of apoptotic T lymphocytes. Cell Death Differ 6:262-270. 
Vermes I, Haanen C, Steffens-Nakken H, Reutelingsperger C.1995.A novel assay for apoptosis: flow cytometric detection of phosphatidylserine expression on early apoptotic cells using fluorescein labelled annexin-V. J Immunol Methods 184:3951.

Vondráček J, Štika J, Souček K, Minksová K, Bláha L, Hofmanová J, KozubíK A.2001. Inhibitors of arachidonic acid metabolism potentiate tumour necrosis factor- $\alpha$ induced apoptosis in HL-60 cells. Eur J Pharmacol 424:1-11.

Wang HP, Qian SY, Schafer FQ, Domann FE, Oberley LW, Buettner GR.2001.

Phospholipid hydroperoxide glutathione peroxidase protects against singlet oxygen-induced cell damage of photodynamic therapy. Free Radical Bio Med 30:825-835.

Wang N, Yao X, Ishii R, Kitanaka S.2001.Antiallergic agents from natural sources. 3. Structures and inhibitory effects on nitric oxide production and histamine release of 5 novel polyacetylene glucosides from Bidens parviflora Willd. Chem Pharm Bull 49:938-942.

Wat CK, Biswas RK, Graham EA, Bohm L, Towers GH, Waygood ER.1979.Ultravioletmediated cytotoxic activity of phenylheptatriyne from Bidens pilosa. J Nat Prod 42:102-111.

Yamaguchi S, Sakurada S, Nagumo M.1994.Role of intracellular SOD in protecting human leukemic and cancer cells against superoxide and radiation. Free Radical Bio Med 17:389-395.

Yamazaki M, Hirakura K, Miyaichi Y, Imakura K, Kita M, Chiba K, Mohri T.2001. Effect of polyacetylenes on the neurite outgrowth of neuronal culture cells and scopolamine-induced memory impairment in mice. Biol Pharm Bull 24:1434-6. 


\title{
DRUG POTENTIATING EFFECT OF PHENYHEPTATRIYNE (PHT) IN THE MULTI-DRUG RESISTANT (MDR) CELL LINE CEM/VLB 100
}

\begin{abstract}
The purpose of this study was to determine the relative toxicity and evaluate the chemosensitizng potential of the phototoxin phenylheptatriyne (PHT) in the CCRF-CEM and CEM/VLB 100 acute lymphoblastic leukemia (ALL) cell lines, under attenuated light conditions. The tetrazolium dye (MTT) assay was used to assess the metabolic activity of cells after incubation for 48 hours with doses of PHT ranging from $0-300 \mu \mathrm{M}$ and doses of doxorubicin from $0-20 \mu \mathrm{M}$ alone or in combination with $60 \mu \mathrm{M}$ PHT. The multi-drug resistant (MDR) $\mathrm{CEM} / \mathrm{VLB}_{100}$ cell line was more sensitive to PHT toxicity than the parental CEM cell line $(P=0.006)$. The combination of $\mathrm{PHT}$ and doxorubicin was more toxic than doxorubicin alone $(P=0.007)$.

The multi-drug resistant (MDR) variant $C E M / V^{2} B_{100}$ cell line expresses the $m d r-1$ gene product, P-glycoprotein ( $p g p-170)$, a $170 \mathrm{kD}$ protein present in the plasma membrane and is cross-resistant to vinblastine and doxorubicin. PHT may work additively or synergistically with doxorubicin by a mechanism that involves changes in plasma membrane fluidity. As a fatty acid derivative that intercalates plasma membranes, PHT could affect physical membrane properties and thus modify the uptake of doxorubicin. Further work should focus on examination of the chemosensitizing activity of PHT in cell lines expressing the $190 \mathrm{kD}$ multi-drug resistance associated protein $(M R P-1)$ and in combination with anti-tumor drugs, including epipodophyllotoxins and camptothecin.
\end{abstract}




\section{INTRODUCTION}

The increased morbidity and mortality associated with the multidrug resistant (MDR) phenotypes of cancer cells and microbes has prompted the need for new medicines and treatment modalities with the ability to chemosensitize cells or interfere with resistance mechanisms (Liscovitch et al., 2002). Multiple drug resistance involves the insensitivity of cancer cells to a diversity of anti-tumor agents with varying structures and different mechanisms of action (Bosch et al., 1996). Chemotherapeutic agents associated with the acquired MDR phenotype include the vinca alkaloids (vinblastine, vincristine and vinorelbine), epidophyllotoxins (etoposide, teniposide), taxanes (taxol, paclitaxel and docetaxel), and anthracyclines (doxorubicin, daunorubicin, idarubicin) (Baggetto et al., 1998).

Decreased cellular drug influx and increased cellular ability for drug extrusion are the main mechanisms involved in MDR (Bosch et al., 1996). Tumors may be intrinsically resistant to chemotherapeutic drugs or acquire resistance after exposure to drugs. In both cases, chemotherapy may fail because the patient does not respond either initially or after relapse (Liscovitch et al., 2002). In order to achieve high complete remission rates with pediatric ALL patients, intensive multiagent chemotherapy, or induction therapy, is often necessary (Silverman et al., 1999). Unfortunately, patients may not respond to therapy even though they are treated with combinations of highly toxic and immunosupressive drugs such as doxorubicin, dexamethasone, vincristine, methotrexate, prednisolone, and cytosine arabinoside. 
MDR is mediated by the ATP binding cassette (ABC) transporters p-glycoprotein $(p g p-170)$ and the multidrug resistance associated protein-1 (MRP-1). It is an ATPase dependent multidrug transporter potentially responsible for MDR in many tumors. $M R P$ 1 transports cationic and neutral compounds only in the presence of glutathione, or as glutathione-S-conjugates (Kolk et al., 2000). MRP1 is a 190-kDa protein that shares $15 \%$ amino acid homology with Pgp-170.

$P g p-170$ is a target for modulation by pharmacological inhibitors because its expression can be increased at diagnosis or after chemotherapy. Its expression confers a poor prognosis in elderly adults with acute myeloid leukemia (AML) (Kolk et al., 2000). $P g p-170$ expression has been detected in children with AML and less commonly in children with ALL (Lacayo et al., 2002). The administration of pgp-170 inhibitors can increase the accumulation of cytotoxic drugs in the cancer cells of leukemia patients or conversely, result in increased toxicity.

MDR can be partially reversed with drug resistance modulators, also called chemosensitizers, by increasing intracellular drug accumulation. Compounds with chemosensitizing activity include the calcium antagonists (verapamil), calmodulin inhibitors, phenothiazines, anti-malarial (mefloquine) and anti-arrhythmic drugs (quinidine), immunosuppressants (cyclosporin-A) and steroid hormones (Hill et al., 1994). Unfortunately, these chemosensitizers are highly cardiotoxic, neurotoxic, or otherwise intolerable at their effective doses and thus have limited use (Kutlay et al., 1997).

The drug extrusion function of $p g p$-170 might also be compromised through changes in the composition and fluidity of the plasma cell membrane. The more 
lipophilic a compound, the faster it will diffuse through a lipid membrane and chemosensitizers show faster permeation kinetics through model membranes than pgp170 substrates (Ferté, 2000). Moreover, the efficiency of $p g p-170$ to reduce intracellular drug accumulation decreases as the lipophilicity of the drug increases and chemosensitizing activity increases as the lipophilicity of the modulator increases. However, it is still uncertain if $p g p-170$ is inhibited directly interaction or indirectly, through its effects on the membrane (Ferté, 2000).

The alteration of membrane transport as a mechanism of drug resistance may involve changes in the fluidity, composition and/or asymmetry of the plasma membrane. Fatty acids and their derivatives and even fatty acid derived pro-drugs of anti-cancer agents serve as valuable models for increasing understanding of this phenomenon (Bergman et al., 2004).

Fatty acids and their derivatives show structure dependent cytotoxicity in cancer cell lines and are able to potentiate the effect of certain anticancer drugs when used in drug combinations (Das et al., 1998). Considerable data support the hypothesis that the ability of fatty acids to modify the fluidity of the plasma membrane contributes to their efficacy as chemosensitizers or resistance modulators. Doxorubicin sensitivity has been found to increase with the degree of unsaturation of fatty acids in enriched cellular phospholipids (Burns et al., 1986). Enrichment of murine leukemia cells with the omega - 6 PUFA, linoleic acid, modified the phospholipid fatty acid composition of the plasma membrane and sensitized the cells to doxorubicin-induced toxicity (Burns et al., 1987). The omega-3 fatty acid, docosahexaenoic acid (DHA) increased the cytotoxicity of doxorubicin in human glioblastoma cells (Rudra et al., 2001). The omega-6, gamma- 
linoleic acid (GLA) and the omega -3 fatty acid, eicosapentaenoic acid (EPA), potentiated the cytotoxicity of vincristine, cisplatin and doxorubicin in human cervical carcinoma cells in vitro (Das et al. 1998). Nontoxic concentrations of EPA diester increased the intracellular drug accumulation and retention and sensitivity of pgp-170 expressing multi-drug resistant breast carcinoma cells to doxorubicin as monitored by doxorubicin auto fluorescence and MTT tetrazolium salt reduction (Abulrob et al., 2000). As a fatty acid derivative that intercalates plasma membranes, PHT could affect physical membrane properties and thus modify the uptake of doxorubicin. The anthracycline, doxorubicin (Adriamycin $®$ ), is a naturally derived quinoid compound produced by Streptomyces that has potent antibiotic and anti-neoplastic activity. Doxorubicin efficacy is severely compromised by the overexpression of $p g p-170$ (Thomas et al., 2003). However, anthracycline analogues have been developed to have higher affinity for lipid membranes, and in vitro and in vivo data demonstrate their ability to overcome $p g p-170$ mediated drug resistance. These compounds are not without side effects though and like doxorubicin cause cardiotoxicity.

In this study, the toxicity of suboptimal doses of PHT in combination with doxorubicin was evaluated in the $p g p-170$ overexpressing MDR, CEM/VLB 100 cell line that shows cross resistance to vinca alkaloids and anthracyclines. The MTT tetrazolium assay was used to assess toxicity of PHT alone after a 48 hour incubation period in the parental CCRF-CEM cell line and the CEM/VLB 100 cell line. A suboptimal concentration of PHT was chosen for toxicity testing in combination with doxorubicin.

The MTT assay has shown to be reliable for in vitro study of drug interactions in ALL bone and peripheral blood samples (Kaspers et al., 1995). Moreover, the use of 
tetrazolium salt assays for the in vitro screening of drug combinations in pediatric ALL bone marrow specimens, is recommended for identifying the combinations with the greatest likelihood of success in induction therapy (Silverman et al., 1999). The combination of PHT and doxorubicin was more toxic than either drug alone. The two drugs may act supra-additively in this cell line. Further data are needed to determine if PHT potentiates doxorubicin toxicity by disturbing $p g p-170$ drug extrusion and/or though modulating membrane permeability to cause increased doxorubicin uptake.

\section{MATERIALS AND METHODS}

Chemicals and reagents.

Viability was assessed by reduction of 3-(4,5-dimethylthiazol-2-yl)-2,5diphenyltetrazolium bromide (MTT) purchased from either ATCC (Manassas, VA. cat. $\# 30-1010 \mathrm{~K}$ ) or Roche (Indianapolis, IN cat. \#1465007) and trypan blue exclusion (Invitrogen, cat. \#15250-061). Cell culture media, supplements and drugs included the following, all of which were purchased from Invitrogen (Carlsbad, CA). RPMI-1640 medium (cat. \#1 1875-093), phosphate buffered saline (PBS) (cat. \#14200-075), penicillin-streptomycin (cat. \#15140-148), L-glutamine (Cat. \# 25030-149), fetal bovine serum (FBS) (Cat. \# 10082-147), doxorubicin (Cat. \# D1317). 


\section{Sample preparation.}

Dilutions of doxorubicin hydrochloride were prepared using phosphate buffered saline (PBS) to final concentrations of $0-20 \mu \mathrm{M}$. PHT was extracted and purified from the fresh leaves of $B$. alba var. radiata according to the procedure described in Chapter 1 of this thesis. PHT was solubilized in $95 \%$ ethanol and dilutions were prepared in culture media to final concentrations ranging $0-300 \mu \mathrm{M}$.

Cytotoxicity of PHT in the absence of controlled UVA irradiation.

CCRF-CEM and CEM/VLB ${ }_{100}$ cells were harvested from $75 \mathrm{~cm}^{2}$ tissue culture flasks by centrifugation when they reached in the exponential growth phase $\left(8 \times 10^{5}-1.2\right.$ $\times 10^{6}$ cells $/ \mathrm{ml}$ ). Cells were washed in PBS warmed to $37^{\circ} \mathrm{C}$ and then centrifuged at $250 \mathrm{~g}$ $(1115 \mathrm{rpm})$. The were then resuspended in medium to a density of $1 \times 10^{6}$ cells $/ \mathrm{ml}$ and cultured in 24-well plates with $1 \mathrm{ml}$ of cell suspension in each. Medium containing negative controls (cells alone and cells $+0.5 \%$ ethanol), positive controls $(4 \mu \mathrm{g} / \mathrm{ml}$ Camptothecin) or drug treatments was then added to a final volume of $2 \mathrm{ml}$, for a final cell density of in each well of $5 \times 10^{5} \mathrm{cell} / \mathrm{ml}$.

Cell cultures were treated in triplicate with concentrations of PHT ranging from 0$300 \mu \mathrm{M}$ for 48 hours, and then transferred to 96 -well assay plates with 4-8 replicates per treatment. MTT was added to a final concentration of $5 \mu \mathrm{g} / \mathrm{ml}$ in each well. After giving the cells $6-8$ hours to reduce the tetrazolium salt, a solubilizing solution containing $0.1 \mathrm{~N}$ HCL and anhydrous isopropanol was added to solubilize the formazan crystals. After dissolving the formazan crystals for 12 hours, the absorbance was read at $570 \mathrm{~nm}$ with a reference wavelength at $655 \mathrm{~nm}$. The mean absorbance of wells containing media, MTT 
and solubilizing solution only was subtracted from the mean absorbance of the treatment wells. Data is expressed as the mean percent absorbance of the vehicle control $(0.5 \%$ ethanol). At least 3-5 independent experiments were performed.

Cytotoxicity of doxorubicin and PHT.

Assay conditions were as described above. Viability of cells was assessed by MTT reduction after 48 hour incubation with media containing different concentrations of doxorubicin in combination with $60 \mu \mathrm{M}$ PHT. Each treatment was replicated 6 times within an assay and repeated independently 3 times.

Statistical Analyses.

Statistical analyses were performed by one and two-way analysis of variance (ANOVA) using SigmaStat for Windows, Version 3.00.0. Results were considered significant if $\mathrm{P}<0.05$. Subsequently, pairwise multiple comparison procedures were performed using the Holm-Sidak method. Tests of normality were performed on all data. If the data failed normality tests, a Kruskal-Wallis one-way ANOVA on ranks and a Mann-Whitney Rank sum test were performed.

\section{RESULTS}

Viability of Cell Cultures after PHT Treatment.

The tetrazolium salt, MTT assay was used in order to determine the viability of CCRF-CEM and CEM/VLB ${ }_{100}$ cell lines, under attenuated light conditions, after incubation for 48 hours with drug concentrations ranging from $0-300 \mu \mathrm{M}$ (figure 3.1 and table 3.1). 
After 48 hours incubation with PHT, the CEM/VLB 100 cell populations showed less metabolic activity than CCRF-CEM cells, across the levels of concentration used (P $=0.003$ ). There was also a concentration dependent effect on the mean percent of metabolically active cells, relative to control, across both cell lines $(P=0.007)$.

The median percent viable cells in $\mathrm{CEM} / \mathrm{VLB}_{100}$ cell populations was considerably less than in the CEM populations $(P=0.006$, Kruskal-Wallis one-way ANOVA; $\mathrm{P}=0.007$, Mann-Whitney Rank sum test).

Cytotoxicity PHT combined with Doxorubicin in CEM/VLB $B_{100}$ cells.

Cell cultures treated with both doxorubicin and $60 \mu \mathrm{M}$ PHT were significantly less viable $(P=0.007)$ than to those treated with doxorubicin alone, across combination treatments tested. The results indicate additive or supra-additive effect on metabolic activity with combinations of $60 \mu \mathrm{M}$ PHT and doxorubicin at less than $10 \mu \mathrm{M}$ (figure 3.2 and table 3.2).

\section{DISCUSSION}

PHT is a fatty acid derivative produced in the medicinal plant Bidens alba var. radiata. PAs are secondary metabolites of polyunsaturated fatty acids (PUFAs) occurring in many plant families, most notably the Asteraceae, Apiacae, and Araliaceae that participate in defense against herbivores. In this study, the MDR cell line $\mathrm{CEM} / \mathrm{VLB}_{100}$ showed greater sensitivity to the toxicity of PHT than the parental cell line CCRF-CEM across the concentrations tested. CEM/VLB ${ }_{100}$ cells treated with a suboptimal dose of PHT $(60 \mu \mathrm{M})$ in combination with less than $10 \mu \mathrm{M}$ doxorubicin showed a greater loss in viability than either drug alone after a 48 hour incubation period. 
PHT is an established phototoxin and studies using liposome models show its activity to be affected by the fluidity or lipid composition of the membrane (Wat $e t$ al., 1979; McRae et al., 1985). More data is needed to understand how PHT affects the biophysical properties of the plasma membrane in mammalian cell models when not photo-excited. It is a linear, rigid molecule that intercalates cell membranes due to its lipophilic nature and it is these characteristics that may contribute to its cytotoxic and chemosensitizing effect, in the absence of light excitation, in this MDR cell model. In chapter 2 of this thesis, it was reported that PHT induced changes in the asymmetry and integrity of the plasma membrane in $\mathrm{CEM} / \mathrm{VLB}_{100}$ cells in a concentration-dependent manner, in the absence on light excitation, after 24 hours. This effect could be observed at concentrations of PHT as low as $40 \mu \mathrm{M}$, after 24 hours.

Compounds that modulate multi-drug resistance represent a diversity of chemical structures but they share the common property of lipophilicity. This property facilitates interactions with the lipid bilayer that result in biophysical modifications. Studies show these modifications to be highly correlated with the reversal of MDR. The biophysical parameters that accompany chemosensitization may include an increase or decrease in membrane fluidity (decrease or increase in membrane order, respectively) depending on the cell type. Cancer cell membranes have altered membrane composition relative to normal cells and acquired resistance to chemotherapeutic drugs is often accompanied by changes in membrane order (Wilder et al., 1990). These changes may directly or indirectly modify the function of drug transporters such as $p g p-170$ and $M R P-1$ (Hendrich et al., 2003). 
It is not clear whether decreased order of the plasma membrane interferes with resistance mechanisms of cancer cells, either by altering the function of the transmembrane glycoprotein $p g p-170$, or if membrane alterations alone are sufficient to impart decreased resistance (Liang et al., 2004). Other investigators (Aleman et al., 2003) have concluded that expression of $p g p$-170 does not affect membrane order or membrane potential, as measured by fluorescent anisotropy probe or electron spin resonance (ESR) probe or the fluorescent probe, oxonol. They discovered that cells expressing pgp-170 and selected for resistance by low-level exposure to drugs over time had more fluid (less ordered) membranes and increased membrane potential as opposed to cells created by transfection with $m d r l$ gene cDNA.

Some studies report that reversal of drug resistance is accompanied by either an increase or a decrease in lipid order. The surfactants, Solutol HS-15, Tween 40, and Cremophore EL, decreased membrane fluidity as measured by steady-state fluorescence polarization experiments and increased pgp-170 substrate accumulation in colchicine resistance selected, KB-8-5-11 MDR human epidermoid carcinoma cells, through increased uptake of rhodamine-123 (Dudeja et al., 1995). Siegfried et al. (1983) studied the membrane properties of doxorubicin sensitive and resistant cell lines using ESR and found a significant difference in the order parameter, a measure of membrane fluidity, between the cell lines. A progressive decrease in the order parameter (or increase in membrane fluidity) was observed as resistance to doxorubucin increased.

Studies of the biophysical differences in plasma membranes of Cisdiamminodichloroplatinum II (cisplatin) sensitive and cisplatin selected, resistant epidermal carcinoma cells (KB-3-1 and KCP-20 cells) using ESR and fluorescence 
polarization studies showed that drug selected resistance to cisplatin increased membrane fluidity relative to sensitive cells and enrichment of cells with the C-17 saturated fatty acid, heptadecanoic acid, further increased fluidity (decreased the order parameter) of both cell lines (Liang et al., 2004). This change in the biophysical parameters of the cell membranes increased the resistance of KCP-20 cells to cisplatin toxicity but did not affect the sensitivity of the parental cell line. In this case, an increase in fluidity was accompanied by an increase in drug resistance in the MDR cell line. Further data were needed in order to determine if the fluidity change was directly responsible for the modified resistance or if it could be attributed to differences in fatty acid composition.

The drug sensitive MCF-7 and doxorubicin resistant MCF-7/ADR breast cancer cell line also represent an acquired MDR model. In this study, the MCF/ADR cell line was selected for doxorubicin resistance. These cells were pretreated for 24 hours with EPA diester in $0.1 \%$ ethanol and then incubated in the presence of both doxorubicin and the fatty acid. EPA diester potentiated the activity of the $p g p-170$ blocker, verapamil, by increasing the accumulation and retention of the model pgp-170 substrate rhodaine- 123 (Abulrob et al., 2000).

Callaghan et al. (1993) studied the biophysical properties of the drug sensitive $\mathrm{AB} 1$ and vinblastine resistant $\mathrm{CHRC} 5$ cell lines by monitoring the uptake of rhodamine dyes after enrichment with heptadecanoic acid and treatment with vinblastine or after treating the cells with rigidifying agents such as stearic acid and cholesterol derivatives or with the membrane order decreasing PUFAs. The uptake of vinblastine increased in the resistant but not the sensitive cell line and the uptake of rhodamine dyes increased in response to both rigidification and fluidization (decreased membrane order). 
The drug resistant Chinese hamster ovary cell line had higher plasma membrane structural order as compared to the sensitive cell line and treatment with the pgp-170 inhibitor, verapamil, and the bile salt, taurochenodeoxycholate (TCDC), resulted in lower membrane order (or increased membrane fluidity) as demonstrated using ESR and consequent sensitization to the pgp-170 substrates mitomycin and doxorubicin (Shuldes et al., 2001).

Using fluorescence spectroscopy and microcalorimetry for measurements of biophysical effects on membranes, and flow cytometry with the fluorescent $p g p-170$ substrate $\mathrm{DiOC}_{2}$, to evaluate intracellular drug accumulation, Hendrich et al. (2003) demonstrated that intercalation of the most hydrophobic phenothiazine derivatives in the plasma membrane caused a perturbation in the bilayer structure or lipid matrix, in addition to inhibition of pgp-170 activity.

The effects of in vitro development of resistance to fluconazole on membrane fluidity and asymmetry of Candida albicans isolates were monitored by Kohli et al. (2002) using fluorescent polarization measurements and detection of phosphatidylethanolamine (PE) on the outer leaflet of the membrane. The drug resistant strains showed enhanced membrane fluidity compared to the sensitive strains and decreased membrane asymmetry demonstrated by greater exposure of PE on the out layer of the plasma membrane (Kohli et al., 2002).

These studies demonstrate that membrane changes in the order, asymmetry and composition are associated with drug resistance. The selectivity of PHT toxicity in the $\mathrm{CEM} / \mathrm{VLB}_{100}$ cell line was proposed to be due to differences in the endogenous enzymatic antioxidant defenses of cells and in need of further study (see chapter 2). In 
addition, a selective membrane level effect was observed under attenuated light conditions as shown by a loss in membrane asymmetry. Because redox status and membrane alterations are believed to be involved in the evolution of drug resistance, further evaluation of the chemosensitizing potential of PHT should be performed. Electron paramagnetic spin resonance (ESR) studies may help to elucidate the effect of PHT on membrane order. PHT may show selective toxicity that is determined by the antioxidant status of the cell and composition and hence relative fluidity of the membrane. In addition, PHT might disturb the lipid matrix of cell membranes to inhibit membrane efflux pumps such as $p g p-170$. 


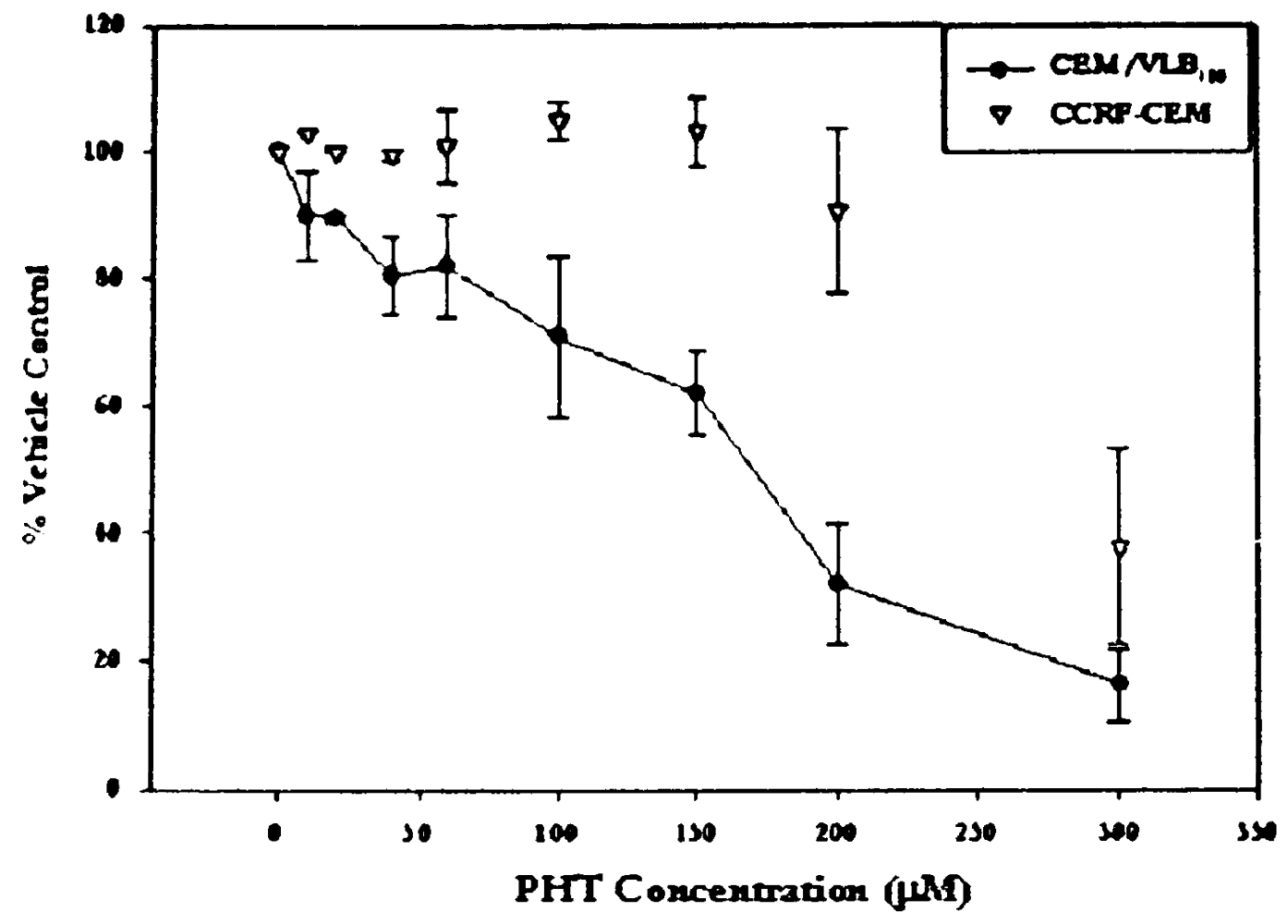

Figure 3.1. Metabolic activity of CCRF-CEM and CEM/VLB 100 cells after 48 hour incubation with PHT. Data points represent the mean percent of the vehicle control $(0.5 \%$ ethanol) absorbance of reduced MTT at $570 \mathrm{~nm}$, for each treatment concentration. Error bars represent the SE of the mean for 3-5 independent experiments. Each treatment was replicated 4-8 times within each experiment. 
Table 3.1. Metabolic activity of CCRF-CEM and CEM/VLB 100 cell line cultures after 48 hour PHT treatment with varying concentrations.'

\begin{tabular}{ccc} 
& CCRF-CEM & CEMN LB \\
\cline { 2 - 3 } PHT Concentr etion ( $\mu$ M) & \% Control & \%o Control \\
\hline 0 & 100 & 100 \\
10 & $102.9 \pm 0.4$ & $89.9 \pm 6.8$ \\
20 & $100.1 \pm 0.3$ & $89.4 \pm 0.5$ \\
40 & $99.6 \pm 0.8$ & $80.4 \pm 6.2$ \\
60 & $100.9 \pm 5.8$ & $81.8 \pm 7.9$ \\
100 & $104.9 \pm 3.0$ & $70.7 \pm 12.6$ \\
150 & $103.1 \pm 5.5$ & $61.8 \pm 6.5$ \\
200 & $90.5 \pm 12.9$ & $31.9 \pm 9.5$ \\
300 & $37.8 \pm 10.4$ & $16.0 \pm 5.6$
\end{tabular}

1. Values represent percent $(\%)$ vehicle control $(0.5 \%$ ethanol $) \pm \mathrm{SE}$ of the mean. 


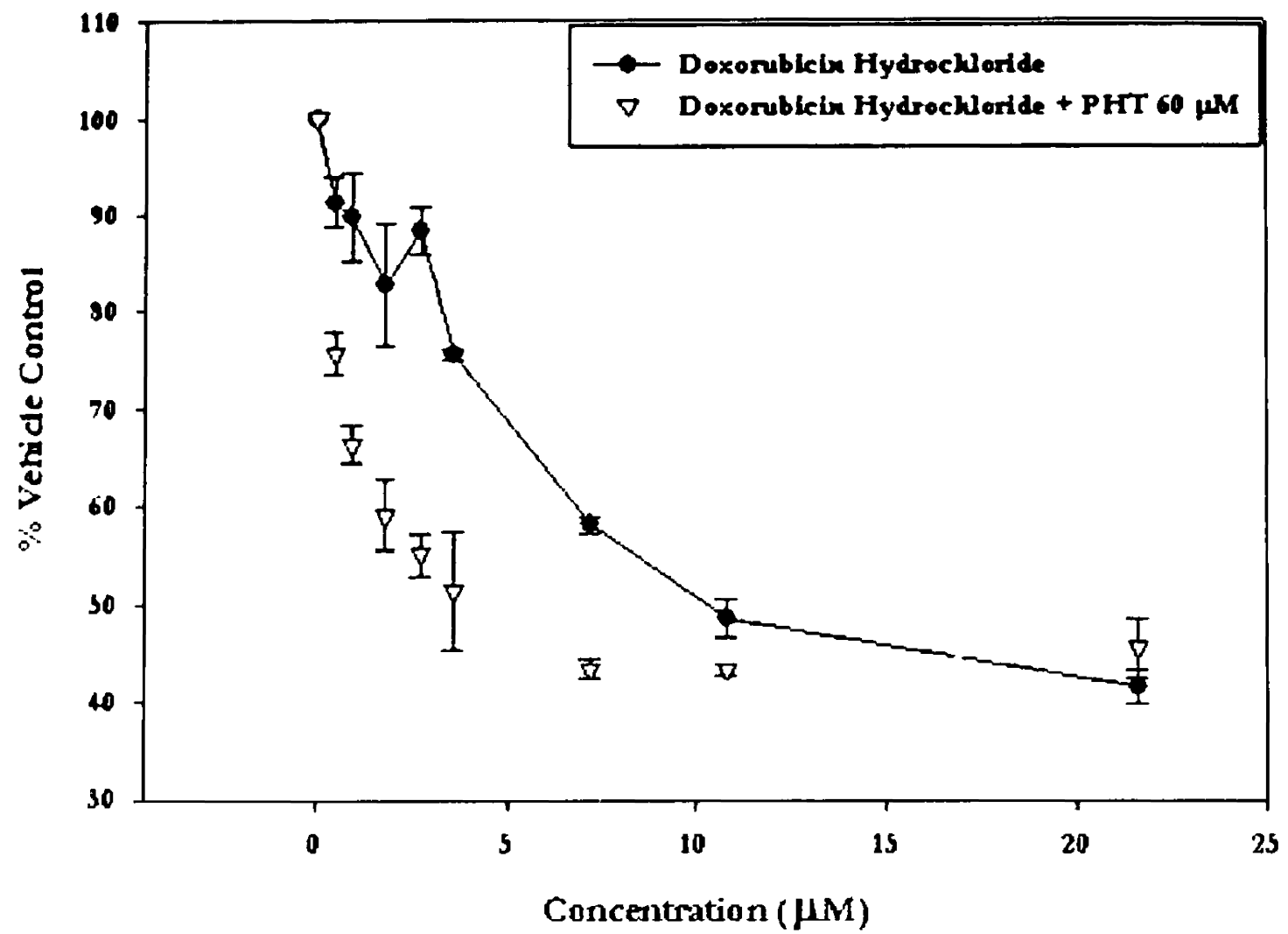

Figure 3.2. Metabolic activity of CEM/VLB 100 cells after 48 hour incubation with either Doxorubicin, or Doxorubicin $+60 \mu \mathrm{M}$ PHT. Each data point represents the mean percent absorbance at $570 \mathrm{~nm}$, of the negative vehicle control. The vehicle control was $0.5 \%$ ethanol. Error bars represent the SE of the mean of 3 independent experiments. Each treatment was replicated 4-8 times within each experiment. A greater loss in viability, as measured by MTT reduction, was observed in the cells treated with both doxorubicin and $60 \mu \mathrm{M}$ PHT ( $\mathrm{P}=0.007$, two-way ANOVA Holm-Sidak method) as compared to those treated with doxorubicin alone. 
Table 3.2. Metabolic activity of $\mathrm{CEM} / \mathrm{VLB}_{100}$ cell line cultures after treatment with doxorubicin (DOX) \pm PHT for 48 hours. $^{1}$

\begin{tabular}{|c|c|c|}
\hline DOX Concentration (pM) & $\%$ Control(D OX A bne) & $\%$ Control(D OX + PHT $60 \mu \mathrm{M})$ \\
\hline 0 & 100 & 100 \\
\hline 0.5 & $91.3 \pm 2.5$ & $75.8 \pm 2.1$ \\
\hline 1.0 & $89.7 \pm 4.6$ & $66.2 \pm 1.9$ \\
\hline 2.0 & $82.8 \pm 6.2$ & $59.1 \pm 3.6$ \\
\hline 3.0 & $88.3 \pm 2.4$ & $55.1 \pm 2.2$ \\
\hline 4.0 & $75.6 \pm 0.6$ & $51.4 \pm 6.1$ \\
\hline 7.5 & $58.1 \pm 0.9$ & $43.4 \pm 0.9$ \\
\hline
\end{tabular}

1. Values represent percent $(\%)$ of vehicle control $(0.5 \%$ ethanol $) \pm S E$ of the mean. 


\section{LITERATURE CITED}

Aleman C, Annereau JP, Liang XJ, Cardarelli CO, Taylor B, Yin JJ, Aszalos A, Gottesman MM.2003.P-glycoprotein, expressed in multidrug resistant cells, is not responsible for alterations in membrane fluidity or membrane potential. Cancer Res 63:3084-3091.

Abulrob AN, Mason M, Bryce R, Gumbleton M.2000.The effect of fatty acids and analogues upon intracellular levels of doxorubicin in cells displaying pglycoprotein mediated multidrug resistance. J DrugTarget 8:247-256.

Baggetto LG, Dong M, Bernaud J, Espinosa L, Rigal D, Bonvallet R, Marthinet E.1998. In vitro and in vivo reversal of cancer cell multidrug resistance by semi-synthetic antibiotic tiamulin. Biochem Pharmacol 56:1219-1228.

Bergman AM, Kuiper CM, Voorn DA, Comijn EM, Myhren F, Sandvold ML, Hendriks HR, Peters GJ.2004.Antiproliferative activity and mechanism of action of fatty acid derivatives of arabinofuranosylcytosine in leukemia and solid tumor cell lines. Biochem Pharmacol 67:503-511.

Bordoni A, Biagi PL, Hrelia S.1999. The impairment of essential fatty acid metabolism as a key factor in doxorubicin-induced damage in cultured rat cardiomyocytes Biochim Biophys Acta 1440:100-106.

Bosch I, Croop J.1996.P-glycoprotein multidrug resistance and cancer. Biochim Biophys Acta 1288:F37-F54.

Burns CP, North JA.1986.Adriamycin transport and sensitivity in fatty acid-modified leukemia cells. Biochim Biophys Acta. 888:10-17.

Burns CP, Spector AA.1987.Membrane fatty acid modification in tumor cells: a potential therapeutic adjunct. Lipids 22:178-184.

Callaghan R, Stafford A, Epand RM.1993.Increased accumulation of drugs in a multidrug resistant cell line by alteration of membrane biophysical properties. Biochim Biophys Acta. 1175:277-282.

Chakrabarti KB, Hopewell JW, Wilding D, Plowman PN.2001.Modification of doxorubicin-induced cardiotoxicity: effect of essential fatty acids and ICRF-187 (dexrazoxane). Eur J Cancer 37:1435-1442.

Das UN.1999.Essential fatty acids, lipid peroxidation and apoptosis. Prostag Leukotr Ess 61:157-163. 
Das UN.1990.Gamma-linolenic acid, arachidonic acid, and eicosapentaenoic acid as potential anticancer drugs. Nutrition 6:429-434.

Das UN, Madhavi N, Sravan KG, Padma M, Sangeetha P.1998.Can tumor cell drug resistance be reversed by essential fatty acids and their metabolites? Prostag Leukotr Ess 58:39-54.

Dudeja PK, Anderson KM, Harris JS, Buckingham L, Coon JS.1995.Reversal of multidrug resistance phenotype by surfactants: relationship to membrane lipid fluidity. Arch Biochem Biophys 319: 309-315.

Ferté J.2000.Analysis of the tangled relationship between p-glycoprotein-mediated multidrug resistance and the lipid phase of the cell membrane. Eur J Biochem 267:277294.

Gewirtz DA.1999.A critical evaluation of the mechanisms of action proposed for the antitumor effects of the anthracycline antibiotics adriamycin and daunorubicin. Biochem Pharmacol 57:727-741.

Hendrich AB, Michalak K.2003.Lipids as a target for drugs modulating multidrug resistance of cancer cells. Curr Drug Targets 4:23-30.

Hendrich AB, Wesolowska O, Motohashi N, Molnár J, Michalak K.2003.New phenothiazine-type multidrug resistance modifiers: anti-MDR activity versus membrane perturbing potency. Biochem Bioph Res Co 304:260-265.

Hill BT, Hosking HK.1994.Differential effectiveness of a range of novel drug-resistance modulators, relative to verapamil, in influencing vinblastine or teniposide cytotoxicity in human lymphoblastoid CCRF-CEM sublines expressing classical or atypical multidrug resistance. Cancer Chemoth Pharm 33:317-324.

Ito A, Cui B, Chavez D, Chai HB, Shin YG, Kawanishi K, Kardono LB, Riswan S, Farnsworth NR, Cordell GA, Pezzuto JM, Kinghorn AD.2001.Cytotoxic polyacetylenes from the twigs of Ochanostachys amentacea. J Nat Prod 64: 2468.

Jung HJ, Min BS, Park JY, Kim YH, Lee HK, Bae KH 2002. Gymnasterkoreaynes A-F, cytotoxic polyacetylenes from Gymnaster koraiensis. J Nat Prod 65:897-901.

Kaspers GJL, Veerman AJP, Pieters R, Van Zantwijk I, Hahlen K, Van Wering ER. 1995.Drug combination testing in acute lymphoblastic leukemia using the MTT assay. Leukemia Res 19: 175-181. 
Kim DK, Lee MY, Lee HS. Lee DS, Lee JR, Lee BJ, Jung JH.2002.Polyacetylenes from a marine sponge Petrosia sp. inhibit DNA replication at the level of initiation. Cancer Lett 185:95-101.

Kohli A, Smriti, Mukhopadhyay K, Rattan A, Prasad R.2002.In vitro low-level resistance to azoles in Candida albicans is associated with changes in membrane fluidity and asymmetry. Antimicrob Agents Ch 46:1046-52.

Kutlay S, Savas S, Yalçin P, Ataman S, Ergin S.1997.Central nervous system toxicity of cyclosporin A treatment in rheumatoid arthritis. Brit J Rheumatol 36:397-399.

Lacayo NJ, Lum BL, Becton DL, Weinstein H, Ravindranath Y, Chang MN, Bomgaars L, Lauer SJ, Sikic BI.2002.Pharmacokinetic interactions of cyclosporine with etoposide and mitoxanthrone in children with acute myeloid leukemia. Leukemia 16:920-927.

Liang XJ, Yin JJ, Zhou JW, Wang PC, Taylor B, Cardarelli C, Kozar M, Forte R, Aszalos A, Gottesman M.2004.Changes in biophysical parameters of plasma membranes influence resistance of sensitive and resistant epidermal carcinoma cells. Exp Cell Res 293:283-291.

Lim YJ, Park HS, Im KS, Lee C, Hong J, Lee M, Kim Dk D, Jung JH.2001.Additional cytotoxic polyacetylenes from the marine sponge Petrosia species. J Nat Prod 64:46-53.

Liscovitch M, Lavie Y.2002.Cancer multidrug resistance: a review of recent drug discovery research. IDrugs 5:349-355.

Liu JH, Zschocke S, Reininger E, Bauer R.1998.Inhibitory effects of Angelica pubescens f. biserrata on 5-lipoxygenase and cyclooxygenase. Planta Med 64:525-529.

Liu QY, Tan BKH.2000.Effects of cis-unsaturated fatty acids on doxorubicin sensitivity in P3888/DOX resistant and P388 parental cell lines. Life Sci 67:1207-1218.

Madhavi N, Das UN.1994.Effect of n-6 and n-3 fatty acids on the survival of vincristine sensitive and resistant human cervical carcinoma cells in vitro. Cancer Lett 84:3141.

Madhavi N, Das UN, Prabha PS, Kumar GS, Koratkar R, Sagar PS.1994.Suppression of human $T$-cell growth in vitro by cis-unsaturated fatty acids: relationship to free radicals and lipid peroxidation. Prostag Leukotr Ess 51:33-40.

Matsuda H, Murakami T, Kageura T, Ninomiya K, Toguchida I, Nishida N, Yoshikawa M.1998. Hepatoprotective and nitric oxide production inhibitory activities of 
coumarin and polyacetylene constituents from the roots of Angelica furcijuga. Bioorg Med Chem Lett 8:2191-6.

McRae DG, Yamamoto E, Towers GHN.1985.The mode of action of polyacetylene and thiophene photosensitizers on liposome permeability to glucose. Biochim Biophys Acta 821:488-496.

Mukhopadhyay K, Kohli A, Prasad R.2002.Drug susceptibilities of yeast cells are affected by membrane lipid composition. Antimicrob Agents Ch 46:3695-3705.

Nakano Y, Matsunaga H, Saita T, Mori M, Katano M, Okabe H.1998.Antiproliferative constituents in Umbelliferae plants II. Screening for polyacetylenes in some Umbelliferae plants, and isolation of panaxynol and falcarindiol from the root of Heracleum moelledorffii. Biol Pharm Bull. 21:257-61.

Okuyama E, Hasegawa T, Matsushita T, Fujimoto H, Ishibashi M, Yamazaki M.2001.Analgesic components of saposhnikovia root (Saposhnikovia divaricata). Chem Pharm Bull 49:154-60.

Öllinger K, Kagedal K.2002.Induction of apoptosis by redox-cycling quinones. Subcellular Biochemistry, volume 36: Phospholipid metabolism in apoptosis. Edited by Quinn and Kagan. Kluwer Academic/Plenum Publishers, New York, 2002.

Pompeia C, Freitas JJS, Kim, JS, Zyngier SB, Curi R.2002.Arachidonic acid cytotoxicity in leukocytes: implications of oxidative stress and eicosanoid synthesis. Biol Cell 94:251-265.

Redl K, Breu W, Davis B, Bauer R.i 994. Anti-inflammatory active polyacetylenes from Bidens campylotheca. Planta Med 60:58-62.

Rudra PK, Krokan HE.2001.Cell-specific enhancement of doxorubicin toxicity in human tumor cells by docosahexaenoic acid. Anticancer Res 21:29-38.

Shack S, Miller A, Liu L, Prasanna P, Thibault A, Samid D.1996.Vulnerability of multidrug-resistant tumor cells to the aromatic fatty acids phenylacetate and phenylbutyrate. Clin Cancer Res 2:865-72.

Shuldes H, Dolderer JH, Zimmer G, Knobloch J, Bickeböller R, Jonas D, Woodcock BG.2001.Reversal of multidrug resistance and increase in plasma membrane fluidity in CHO cells with R-verapamil and bile salts. Eur J Cancer 37: 660-667

Siegfried JA, Kennedy KA, Sartorelli AC, Tritton TR.1983. The role of membranes in the mechanism of action of the antineoplastic agent adriamycin. J Biol Chem 258:339-343. 
Silverman LB, Gelber RD, Young ML, Dalton VK, Barr RD, Sallan SE.1999.Induction failure in acute lymphoblastic leukemia of childhood. Cancer 85:1395-1404.

Stoll BA.2002.N-3 fatty acids and lipid peroxidation in breast cancer inhibition. Brit J Nutr 87:193-198.

Thomas DA, Cortes J, Kantarjian HM.2003.New agents in the treatment of acute lymphocytic leukemia. Best Pract Res Clin Haematol 15:771-790.

Uwai K, Ohashi K, Takaya Y, Ohta T, Tadano T, Kisara K, Shibusawa K. Sakakibara R, Oshima Y.2000.Exploring the structural basis of neurotoxicity in C(17)polyacetylenes isolated from water hemlock. J Med Chem 43:4508-15.

van der Kolk DM, de Vries EG, van Putten WJ, Verdonck LF, Ossenkoppele GJ, Verhoef GEG, Vellenga E.2000.P-glycoprotein and multidrug resistance protein activities in relation to treatment outcome in acute myeloid leukemia. Clin Cancer Res 6:3205-3214.

Wang CN, Shiao YJ, Kuo YH, Chen CC, Lin YL.2000.Inducible nitric oxide synthase inhibitors from Saposhnikovia divaricata and Panax quinquefolium. Planta Med 66:644-7.

Wat CK. Biswas RK, Graham EA, Bohm L, Towers GH, Waygood ER.1979.Ultravioletmediated cytotoxic activity of phenylheptatriyne from Bidens pilosa. J Nat Prod 42:102-111.

Wilder PJ, Overman DK, Tenenholz TC, Gutierrez PL.1990.Differences in myristic acid synthesis and in metabolic rate for P388 cells resistant to doxorubicin. J Lipid Res 31:1973-1982.

Yamazaki M, Hirakura K, Miyaichi Y, Imakura K, Kita M, Chiba K, Mohri T.2001.Effect of polyacetylenes on the neurite outgrowth of neuronal culture cells and scopolamine-induced memory impairment in mice. Biol Pharm Bull 24:14346. 